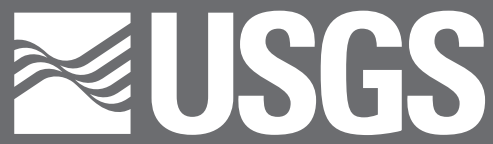

science for a changing world

DOE/ID-22254

Prepared in cooperation with the U.S. Department of Energy

Multilevel Groundwater Monitoring of Hydraulic Head, Water Temperature, and Chemical Constituents in the Eastern Snake River Plain Aquifer, Idaho National Laboratory, Idaho, 2014-18
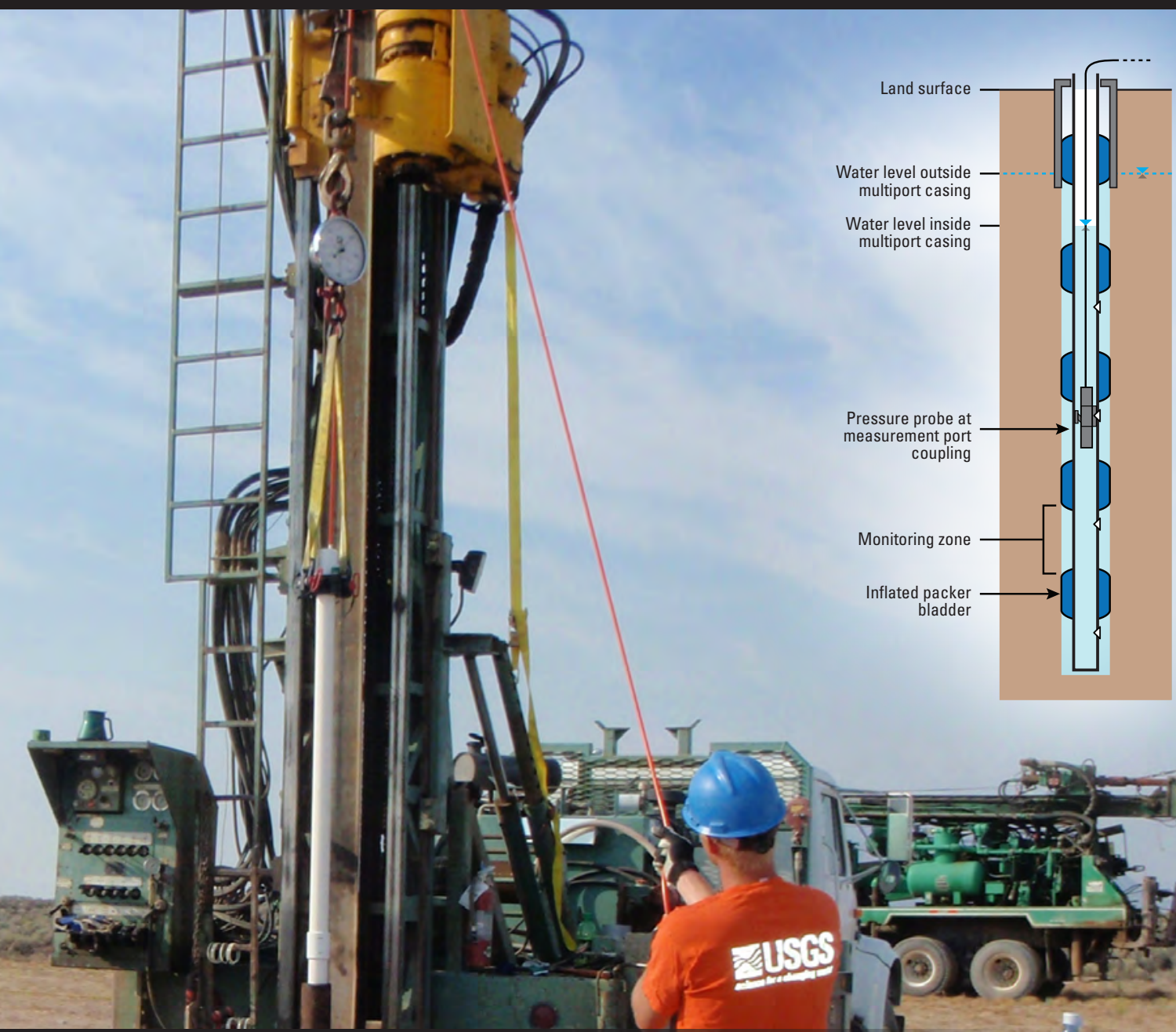

Scientific Investigations Report 2021-5002

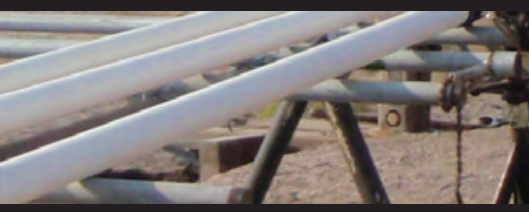

U.S. Department of the Interior U.S. Geological Survey

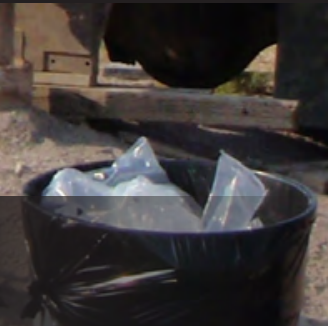


Cover: Photograph showing U.S. Geological Survey drill crew installing multilevel monitoring system and cross section (inset, right) showing components of multi-packer borehole completion and pressure probe used for collecting pressure and temperature measurements , Idaho National Laboratory, Idaho. 


\section{Multilevel Groundwater Monitoring of Hydraulic Head, Water Temperature, and Chemical Constituents in the Eastern Snake River Plain Aquifer, Idaho National Laboratory, Idaho, 2014-18}

By Brian V. Twining, Roy C. Bartholomay, Jason C. Fisher, and Calvin Anderson

DOE/ID-22254

Prepared in cooperation with the U.S. Department of Energy

Scientific Investigations Report 2021-5002 


\section{U.S. Geological Survey, Reston, Virginia: 2021}

For more information on the USGS - the Federal source for science about the Earth, its natural and living resources, natural hazards, and the environment—visit https://www.usgs.gov or call 1-888-ASK-USGS.

For an overview of USGS information products, including maps, imagery, and publications, visit https://store.usgs.gov/.

Any use of trade, firm, or product names is for descriptive purposes only and does not imply endorsement by the U.S. Government.

Although this information product, for the most part, is in the public domain, it also may contain copyrighted materials as noted in the text. Permission to reproduce copyrighted items must be secured from the copyright owner.

Suggested citation:

Twining, B.V., Bartholomay, R.C., Fisher, J.C., and Anderson, C., 2021, Multilevel groundwater monitoring of hydraulic head, water temperature, and chemical constituents in the eastern Snake River Plain aquifer, Idaho National Laboratory, Idaho, 2014-18: U.S. Geological Survey Scientific Investigations Report 2021-5002, 82 p., https://doi.org/ 10.3133/sir20215002.

ISSN 2328-0328 (online) 


\section{Contents}

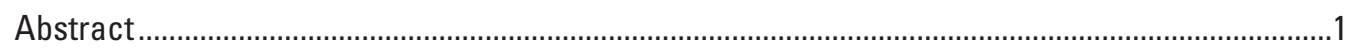

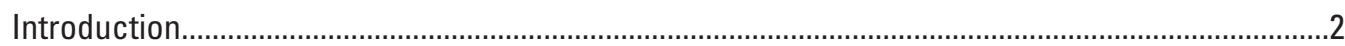

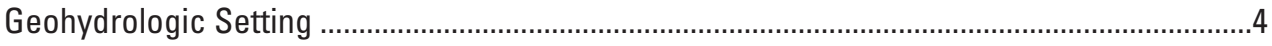

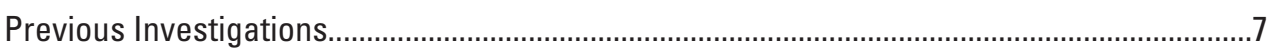

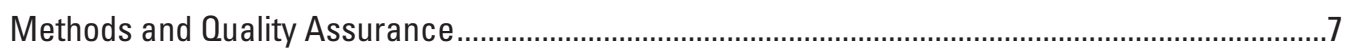

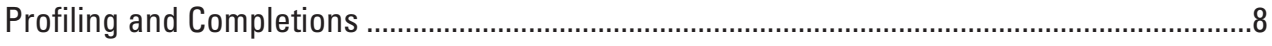

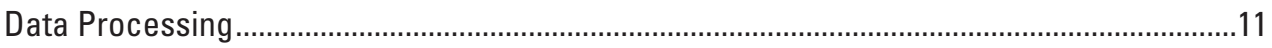

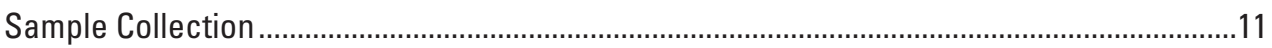

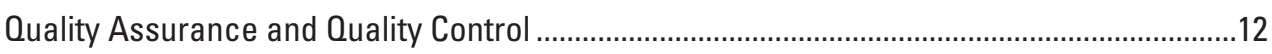

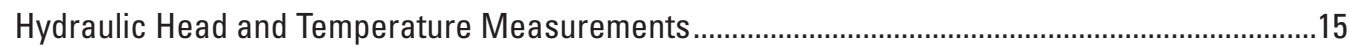

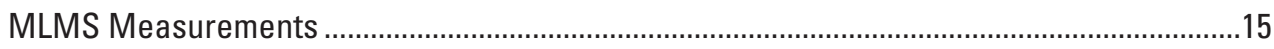

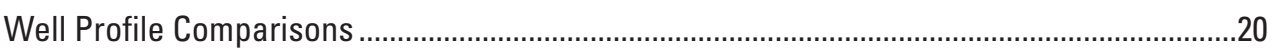

Chemical Constituents in the Eastern Snake River Plain Aquifer.................................................27

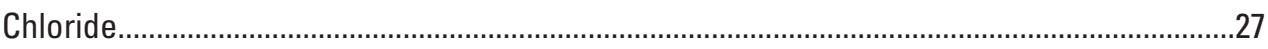

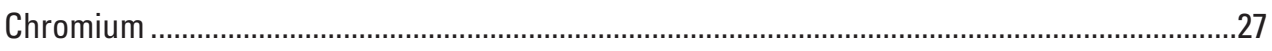

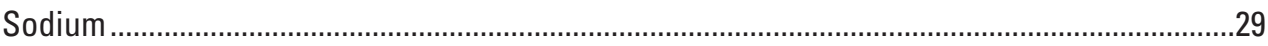

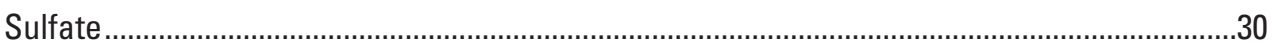

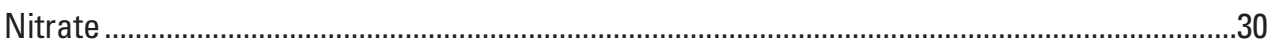

Gross Alpha- and Beta-Particle Radioactivity ...................................................................

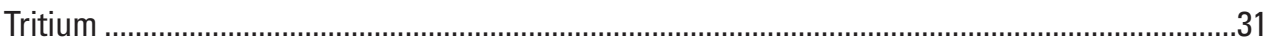

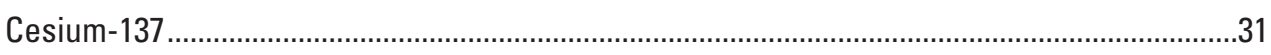

Purgeable Organic Compounds ....................................................................................

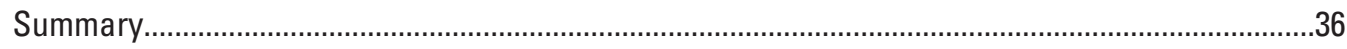

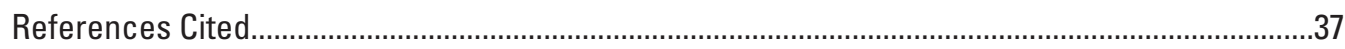

Appendix 1 Paired Port Statistics for Boreholes U.S. Geological Survey (USGS) 103, USGS 105, USGS 108, USGS 131A, USGS 132, USGS 133, USGS 134, USGS 135, and USGS 137A, Idaho National Laboratory, Idaho, 2014-18..........................................82

Appendix 2 Atmospheric Pressure, Water Temperature, Fluid Pressure, and Hydraulic Head Data from Port Measurements for Boreholes U.S. Geological Survey (USGS) 103, USGS 105, USGS 108, USGS 131A, USGS 132, USGS 133, USGS 134, USGS 135, USGS 137A, MIDDLE 2050A, and MIDDLE 2051, Idaho National Laboratory, Idaho, 2014-18.

Appendix 3 Mean and Normalized Mean Hydraulic Head Values for Boreholes U.S. Geological Survey (USGS) 103, USGS 105, USGS 108, USGS 131A, USGS 132, USGS 133, USGS 134, USGS 135, USGS 137A, MIDDLE 2050A, and MIDDLE 2051, Idaho National Laboratory, Idaho, 2007-18... 


\section{Figures}

1. Map showing location of selected facilities, multilevel monitoring wells, and volcanic rift zones bounding the Big Lost Trough, Idaho National Laboratory and vicinity, Idaho.

2. Map showing distribution of hydrogeologic units at the water table and cross section showing well depth in relation to model layers and hydrogeologic units along section $A-A^{\prime}$ ', Idaho National Laboratory and vicinity, Idaho.

3. Schematic showing components of the Westbay ${ }^{\mathrm{TM}}$ Multiport System for multilevel groundwater monitoring.

4. Diagrams showing terms used in the calculation of hydraulic head based on the portable probe position when coupled with a measurement port in the multilevel monitoring system

5. Graphs showing hydraulic head differences between paired-ports and measurement ports in the same monitoring zone in wells U.S. Geological Survey (USGS) 103, USGS 105, USGS 108, USGS 131A, USGS 132, USGS 133, USGS 134, USGS 135, and USGS 137A, Idaho National Laboratory, Idaho, 2014-18.......13

6. Graphs showing hydraulic head differences between paired-ports and measurement ports in the same monitoring zone in wells U.S. Geological Survey (USGS) 103, USGS 105, USGS 108, USGS 131A, USGS 132, USGS 133, USGS 134, USGS 135, USGS 137A, MIDDLE 2050A, and MIDDLE 2051, Idaho National Laboratory, Idaho, 2014-18.

7. Graphs showing individual hydraulic head measurements and suspected erroneous data taken at wells U.S. Geological Survey (USGS) 103, USGS 105, USGS 108, USGS 131A, USGS 132, USGS 133, USGS 134, USGS 135, USGS 137A, MIDDLE 2050A, and MIDDLE 2051, Idaho National Laboratory, Idaho, 2014-18.

8. Graph showing Big Lost River surface water flow measured at U.S. Geological Survey (USGS) streamgage 13132535, Big Lost River at Lincoln Boulevard Bridge, near Atomic City, Idaho National Laboratory, Idaho, January 2014December 2018.

9. Graphs showing quarterly values of the normalized mean hydraulic head at MLMS wells in the Axial Volcanic Zone and Arco-Big Southern Butte Volcanic Rift Zone (wells U.S. Geological Survey [USGS] 103, USGS 105, USGS 108, USGS 131A, and USGS 132), and the Big Lost Trough (wells USGS 133, USGS 134, USGS 135, USGS 137A, MIDDLE 2050A, and MIDDLE 2051), Idaho National Laboratory, Idaho, 2007-18.

10. Survival regression model graphs showing chloride, nitrate, sodium, sulfate, and chromium measured in water samples collected from well MIDDLE 2050A (Site No. 433409112570515), Idaho National Laboratory, Idaho, 2005-18

11. Survival regression model graphs showing tritium measured in water samples collected from wells U.S. Geological Survey (USGS) 103 (Site No. 432714112560702), USGS 103 (Site No. 432714112560704), USGS 103 (Site No. 432714112560708), USGS 103 (Site No. 432714112560712), USGS 105 (Site No. 432703113001807), USGS 105 (Site No. 432703113001811), USGS 105 (Site No. 432703113001815), USGS 131A (Site No. 433036112581810), USGS 131A (Site No. 433036112581815), USGS 132 (Site No. 432906113025018), MIDDLE 2051 (Site No. 433217113004903), and MIDDLE 2051 (Site No. 433217113004909), Idaho National Laboratory Idaho, 2005-18 


\section{Tables}

1. Data for multilevel groundwater monitoring wells, Idaho National Laboratory, 2014-18.

2. Completion data for multilevel wells and associated groundwater model layer information, boreholes U.S. Geological Survey (USGS) 103, USGS 105, USGS 108, USGS 131A, USGS 132, USGS 133, USGS 134, USGS 135, USGS 137A, MIDDLE 2050A, and MIDDLE 2051, Idaho National Laboratory, Idaho, 2014-18.

3. Field measurements of $\mathrm{pH}$, specific conductance, water temperature, and dissolved oxygen in water from multiple levels in the eastern Snake River Plain aquifer, Idaho National Laboratory, Idaho, 2014-18.

4. Minimum Pearson correlation coefficients for hydraulic head and temperature profiles at selected wells, Idaho National Laboratory, Idaho, 2014-18

5. Summary of depth range, hydraulic head statistics, fluid temperature statistics, average water-level depth, and saturated thickness of the aquifer at each borehole, Idaho National Laboratory, Idaho, 2014-18

6. Concentrations of dissolved chloride, chromium, sodium, and sulfate in water from multiple levels in the eastern Snake River Plain aquifer, Idaho National Laboratory, Idaho, 2014-18.

7. Concentrations of dissolved nutrients in water from multiple levels in the eastern Snake River Plain aquifer, Idaho National Laboratory, Idaho, 2014-18

8. Concentrations of gross alpha-particle radioactivity, gross-beta particle radioactivity, tritium, and cesium-137 in water from multiple levels in the eastern Snake River Plain aquifer, Idaho National Laboratory, Idaho, 2014-18

9. Concentrations of selected chemical and radiochemical constituents in water from well MIDDLE 2051, Idaho National Laboratory, Idaho

10. Concentrations of selected purgeable organic compounds in water from multiple levels of selected wells, Idaho National Laboratory, Idaho 


\section{Conversion Factors}

U.S. customary units to International System of Units

\begin{tabular}{|c|c|c|}
\hline Multiply & By & To obtain \\
\hline \multicolumn{3}{|c|}{ Length } \\
\hline foot $(\mathrm{ft})$ & 0.3048 & meter $(\mathrm{m})$ \\
\hline mile (mi) & 1.609 & kilometer $(\mathrm{km})$ \\
\hline \multicolumn{3}{|c|}{ Area } \\
\hline square mile $\left(\mathrm{mi}^{2}\right)$ & 259.0 & hectare (ha) \\
\hline square mile $\left(\mathrm{mi}^{2}\right)$ & 2.590 & square kilometer $\left(\mathrm{km}^{2}\right)$ \\
\hline \multicolumn{3}{|c|}{ Pressure } \\
\hline pound per square inch $\left(\mathrm{lb} / \mathrm{in}^{2}\right)$ & 6.895 & kilopascal $(\mathrm{kPa})$ \\
\hline \multicolumn{3}{|c|}{ Density } \\
\hline pound per cubic foot $(\mathrm{lb} / \mathrm{ft} 3)$ & 16.02 & kilogram per cubic meter $(\mathrm{kg} / \mathrm{m} 3)$ \\
\hline \multicolumn{3}{|c|}{ Radioactivity } \\
\hline picocurie per liter $(\mathrm{pCi} / \mathrm{L})$ & 0.037 & becquerel per liter $(\mathrm{Bq} / \mathrm{L})$ \\
\hline \multicolumn{3}{|c|}{ Hydraulic conductivity } \\
\hline foot per day (ft/d) & 0.3048 & meter per day $(\mathrm{m} / \mathrm{d})$ \\
\hline \multicolumn{3}{|c|}{ Hydraulic gradient } \\
\hline foot per mile (ft/mi) & 0.1894 & meter per kilometer $(\mathrm{m} / \mathrm{km})$ \\
\hline \multicolumn{3}{|c|}{ Transmissivity } \\
\hline foot squared per day $(\mathrm{ft} 2 / \mathrm{d})$ & 0.09290 & meter squared per day $\left(\mathrm{m}^{2} / \mathrm{d}\right)$ \\
\hline
\end{tabular}

International System of Units to U.S. customary units

\begin{tabular}{|c|c|c|}
\hline Multiply & By & To obtain \\
\hline \multicolumn{3}{|c|}{ Length } \\
\hline micrometer $(\mu \mathrm{m})$ & 0.00003 .937 & inch (in.) \\
\hline centimeter $(\mathrm{cm})$ & 0.3937 & inch (in.) \\
\hline \multicolumn{3}{|c|}{ Volume } \\
\hline liter (L) & 1.057 & quart (qt) \\
\hline liter (L) & 0.2642 & gallon (gal) \\
\hline \multicolumn{3}{|c|}{ Mass } \\
\hline milligram (mg) & 0.00003527 & ounce, avoirdupois (oz) \\
\hline microgram $(\mu \mathrm{g})$ & 0.00000003527 & ounce, avoirdupois (oz) \\
\hline
\end{tabular}

Temperature in degrees Celsius $\left({ }^{\circ} \mathrm{C}\right)$ may be converted to degrees Fahrenheit $\left({ }^{\circ} \mathrm{F}\right)$ as follows:

$$
{ }^{\circ} \mathrm{F}=\left(1.8 \times{ }^{\circ} \mathrm{C}\right)+32 .
$$




\section{Datums}

Vertical coordinate information is referenced to the North American Vertical Datum of 1988 (NAVD 88) or the National Geodetic Vertical Datum of 1929 (NGVD 29), as explicitly noted in the text.

Horizontal coordinate information is referenced to the North American Datum of 1983 (NAD 83).

\section{Supplemental Information}

Specific conductance is given in microsiemens per centimeter at 25 degrees Celsius $(\mu \mathrm{S} / \mathrm{cm}$ at $\left.25^{\circ} \mathrm{C}\right)$.

Concentrations of chemical constituents in water are given in either milligrams per liter (mg/L) or micrograms per liter $(\mu \mathrm{g} / \mathrm{L})$.

Activities for radioactive constituents in water are given in picocuries per liter (pCi/L).

The standard unit for transmissivity is cubic foot per day per square foot times foot of aquifer thickness [(ft3/d)/ft2]ft. In this report, the mathematically reduced form, foot squared per day $(\mathrm{ft} 2 / \mathrm{d})$, is used for convenience. 


\section{Abbreviations}

\begin{tabular}{ll} 
ATR & Advanced Test Reactor Complex \\
AVZ & Axial Volcanic Zone \\
bls & below land surface \\
BLR & Big Lost River \\
CFA & Central Facilities Area \\
Cu & Curie \\
DOE & Department of Energy \\
ESRP & eastern Snake River Plain \\
head & hydraulic head \\
INL & Idaho National Laboratory \\
INTEC & Idaho Nuclear Technology and Engineering Center \\
MLMS & multilevel monitoring system \\
MP & multiport \\
NRF & Naval Reactors Facility \\
PCC & Pearson correlation coefficient \\
PCE & tetrachloroethene \\
POCs & purgeable organic compounds \\
NWOL & National Water Quality Laboratory \\
OA & quality-assurance \\
OC & quality-control \\
PCC & Pearson correlation coefficient \\
RESL & Radiological and Environmental Sciences Laboratory \\
RPD & relative percent difference \\
RWMC & Radioactive Waste Management Complex \\
USGS & U.S. Geological Survey \\
VOC & volatile organic compound \\
VRZ & Volcanic Rift Zone \\
\hline
\end{tabular}




\title{
Multilevel Groundwater Monitoring of Hydraulic Head, Water Temperature, and Chemical Constituents in the Eastern Snake River Plain Aquifer, Idaho National Laboratory, Idaho, 2014-18
}

\author{
By Brian V. Twining, Roy C. Bartholomay, Jason C. Fisher, and Calvin Anderson
}

\section{Abstract}

Radiochemical and chemical wastewater discharged to infiltration ponds and disposal wells since the early 1950s at the Idaho National Laboratory (INL), southeastern Idaho, has affected the water quality of the eastern Snake River Plain (ESRP) aquifer. In 2006, the U.S. Geological Survey (USGS), in cooperation with the U.S. Department of Energy, added a multilevel well-monitoring network to their ongoing monitoring program to begin describing the vertical movement and distribution of the chemical constituents in the ESRP aquifer.

The multilevel monitoring system (MLMS) at the INL has been ongoing since 2006, and this report summarizes data collected during 2014-18 from 11 multilevel monitoring wells. Hydraulic head (head) and groundwater temperature data were collected, including 177 measurements from hydraulically isolated depth intervals from 448.0 to $1,377.6$ feet below land surface. One port (port 3) within well USGS 134 was not monitored owing to a valve failure.

Vertical head and temperature changes were quantified for each of the 11 multilevel monitoring systems. Fractured basalt zones generally had relatively small vertical head differences and showed a higher occurrence within volcanic rift zones. Poor connectivity between fractures and higher vertical gradients generally were attributed to sediment layers and (or) layers of dense basalt. Hydraulic head ranged from 4,415.5 to 4,462.6 feet above the National Geodetic Vertical Datum of 1929; groundwater temperature ranged from 10.4 to 16.8 degrees Celsius.

Normalized mean head values were analyzed for all 11 multilevel monitoring wells for the period of record (2007-18). The mean head values suggest a moderately positive correlation among all MLMS wells and generally reflect regional fluctuations in water levels in response to seasonal climatic changes. MLMS wells within volcanic rift zones and near the southern boundary indicate a temporal correlation that is strongly positive. MLMS wells in the Big Lost Trough indicate some variations in temporal correlations that may result from proximity to the mountain front to the northwest and episodic flow in the Big Lost River drainage system.

During 2014-18, water samples were collected from one to four discrete sampling zones, isolated by packers, in the upper 250-750 feet of the aquifer from 11 multilevel monitoring wells and were analyzed for selected radionuclides, inorganic constituents, organic constituents, and nutrients. Some additional samples were collected for volatile organic compounds from wells near the Radioactive Waste Management Complex (RWMC).

Nine quality-control replicate samples, three field blanks, and two equipment blanks were collected during 2014-18 as a measure of quality assurance. Concentrations of major ions and chromium in equipment blank samples were near or less than the reporting levels, suggesting no background contamination from field equipment or source water. About 88 percent of the replicate pairs for radionuclide results were statistically comparable and 100 percent of the replicate pairs for inorganic and organic compounds were statistically comparable.

Concentrations of chloride, chromium, nitrate, sodium, and sulfate in most of the wells showed mostly consistent concentrations with time. Concentrations in well MIDDLE 2050A were markedly lower during 2017 and 2018 than during other sample years and the decrease in concentrations is attributed to flow in the Big Lost River during those years. Chromium concentrations measured in well USGS 133 increased during this time period. Concentrations of most of the chemical constituents were greater than background concentration levels in wells USGS 103, 105, 108, 131A, 132, 137A, and MIDDLE 2051 , and were at or less than background concentration levels in wells USGS 133, 134, and 135.

Tritium concentrations in wells USGS 108, 133, 134, 135, 137A, and MIDDLE 2050A mostly were less than reporting levels. Concentrations in wells USGS 105 and 132 mostly were greater than the reporting levels, and concentrations were mostly consistent. Wells USGS 103, USGS 131, and MIDDLE 2051 had concentrations mostly greater than the reporting 
level and showed decreasing concentrations. The decreasing concentrations are attributed to discontinued disposal, radioactive decay, and dilution and dispersion in the aquifer.

The volatile organic compound tetrachloromethane was found in all zones sampled in well USGS 132 near the RWMC and was found in two zones in well USGS 137A. Concentrations are attributed to waste disposal at the RWMC. Questionable detections of tetrachloroethene were found in well MIDDLE 2051; the source probably was tubing fluid in the well. Tetrachloroethene was found in the tubing fluid at elevated concentrations in three wells (USGS 137A, MIDDLE 2050A, and MIDDLE 2051), and remedial efforts to remove the elevated concentrations of tetrachloroethene from tubing fluid have been successful in each of the three MLMS wells.

\section{Introduction}

The Idaho National Laboratory (INL), encompassing about $890 \mathrm{mi}^{2}$ of the eastern Snake River Plain (ESRP) in southeastern Idaho (fig. 1), is operated by the U.S. Department of Energy (DOE). The INL was established in 1949 for the development of peacetime atomic energy applications, nuclear safety research, defense programs, environmental research, and advanced energy concepts. Wastewater disposal sites at Test Area North, the Naval Reactors Facility (NRF), the Advanced Test Reactor (ATR) Complex, and the Idaho Nuclear Technology and Engineering Center (INTEC) (fig. 1) have been principal sources of radioactive- and chemicalwaste contaminants in water from the ESRP aquifer. These wastewater disposal sites have included lined evaporation ponds, unlined infiltration ponds and ditches, drain fields, and injection wells. Waste materials buried in shallow pits and trenches within the Subsurface Disposal Area at the Radioactive Waste Management Complex (RWMC) also have contributed contaminants to the groundwater.

Prior to 1984, most of the wastewater generated at the INTEC, which is located in the southwestern part of the INL, was injected directly to the ESRP aquifer through a 598-ftdeep disposal well. In February 1984, routine use of the disposal well was discontinued, and wastewater was then discharged to unlined infiltration ponds south of the INTEC until 2002 (when the ponds were relocated to about 2 mi southwest of the INTEC). The infiltration ponds allowed the wastewater to percolate through about $450 \mathrm{ft}$ of basalt and sediment to the aquifer.

Since 1952, wastewater generated at the ATR Complex has been discharged mostly to ponds. Low-level radioactive wastewater was discharged to infiltration ponds until 1993; since then it has been discharged to evaporation ponds. Nonradioactive wastewater was discharged to the aquifer through a disposal well from 1964 to 1982 and has been discharged to infiltration ponds since 1982 (Bartholomay and others, 2017).
The U.S. Geological Survey (USGS) has maintained a water-quality monitoring program at the INL since 1949 to define (1) the quality and availability of water for human consumption, (2) the usability of the water for supporting construction of facilities and for industrial purposes such as cooling systems and diluting concentrated waste streams, (3) the location and movement of contaminants in the ESRP aquifer, (4) the sources of recharge to the aquifer, (5) an early detection network for contaminants moving past the INL boundaries, and (6) the processes controlling the origin and distribution of contaminants and naturally occurring constituents in the aquifer (Ackerman and others, 2010).

Since the inception of the monitoring program, a network that once numbered almost 200 wells has been sampled for various constituents that may be present in the aquifer from INL waste disposal practices including tritium, strontium-90, cesium-137, plutonium-238, plutonium-239, plutonium-240 (undivided), americium-241, gross alpha- and gross betaradioactivity, iodine-129, chromium and other trace elements, sodium, chloride, sulfate, nitrate, fluoride, volatile organic compounds (VOCs), and total organic carbon (Bartholomay and others, 2017; Maimer and Bartholomay, 2019). Most of the wells in this network were constructed as open-borehole wells, and many of the wells are open to the aquifer through their entire depth below the water table. This type of construction is good for maximum water-production rates, for identifying the time of arrival of contaminant plumes, and for delineating the horizontal extent of contaminants. However, it is not conducive to identifying either the vertical distribution of contaminants or pressure and temperature gradients in the borehole.

To acquire hydraulic head, water temperature, and water-chemistry data that describe the vertical distribution of constituents in the ESRP aquifer, the USGS collaborated with an INL contractor in 2005 to develop a multilevel monitoring network. The multilevel network allows for sampling of discrete zones of water compared to sampling an open, mixed zone. The multilevel monitoring network was expanded by the USGS during 2006-12. In 2005, 2006, and 2007, wells USGS 103, USGS 132, USGS 133, USGS 134, MIDDLE 2050A, and MIDDLE 2051 (fig. 1, table 1) were instrumented; in 2009 through 2012, wells USGS 135, USGS 105, USGS 108, USGS 131A and USGS 137A were instrumented with multilevel Westbay ${ }^{\mathrm{TM}}$ packer sampling systems to acquire pressure and temperature measurements and water-chemistry data at isolated depths in each of the wells. These isolated depths coincide with the vertical location of groundwater model layers (table 2, at back of report; fig. 2) in which particles are introduced to simulate groundwater flow paths (Ackerman and others, 2010), and the data collected from the multilevel monitoring system (MLMS) will improve our information for our next groundwater flow model. 

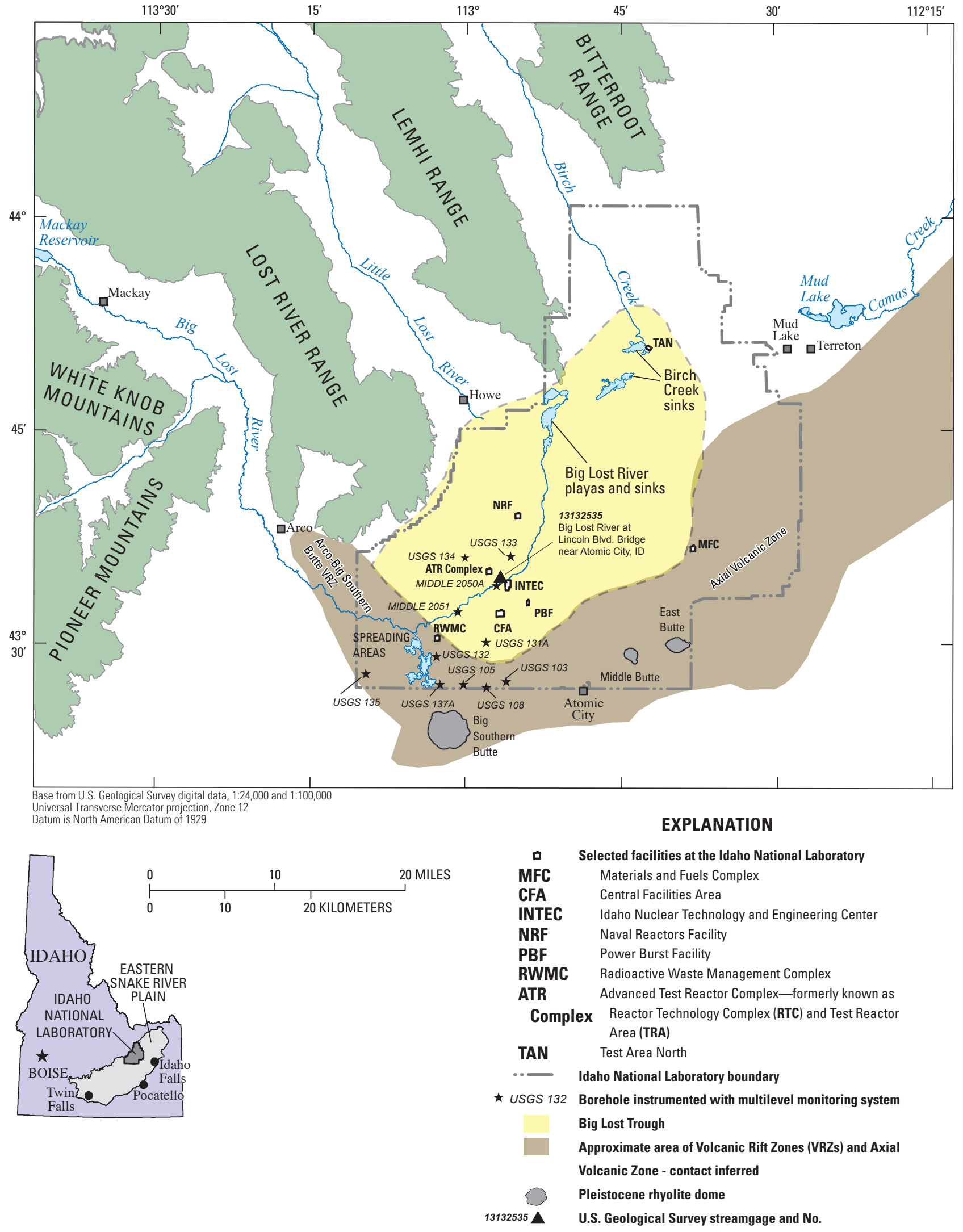

Figure 1. Location of selected facilities, multilevel monitoring wells, and volcanic rift zones bounding the Big Lost Trough, Idaho National Laboratory and vicinity, Idaho. 
Table 1. Data for multilevel groundwater monitoring wells, Idaho National Laboratory, 2014-18.

[Local name: Local well identifier used in this study. USGS, U.S. Geological Survey. Latitude and Longitude: In degrees, minutes, seconds and based on the North American Datum of 1983 (NAD 83). Land-surface altitude: In feet above National Geodetic Vertical Datum of 1929 (NGVD 29). Estimated base of aquifer altitude: In feet above NGVD 29 (Anderson and Liszewski, 1997; Whitehead, 1992). Hole depth: In feet below land surface (ft bls). Site number: Unique numerical identifier used to access well data (https://waterdata.usgs.gov/nwis)]

\begin{tabular}{lcccccc}
\hline Local name & Latitude & Longitude & $\begin{array}{c}\text { Land } \\
\text { surface } \\
\text { altitude } \\
\text { (feet) }\end{array}$ & $\begin{array}{c}\text { Estimated } \\
\text { base of } \\
\text { aquifer } \\
\text { altitude } \\
\text { (feet) }\end{array}$ & $\begin{array}{c}\text { Hole } \\
\text { depth } \\
\text { (ft bls) }\end{array}$ & Site number \\
\hline USGS 103 & $43^{\circ} 27^{\prime} 13.24^{\prime \prime}$ & $112^{\circ} 56^{\prime} 09.51^{\prime \prime}$ & $5,007.42$ & 2,470 & 1,307 & 432714112560701 \\
USGS 105 & $43^{\circ} 27^{\prime} 03.07^{\prime \prime}$ & $113^{\circ} 00^{\prime} 20.77^{\prime \prime}$ & $5,095.12$ & 2,540 & 1,409 & 432703113001801 \\
USGS 108 & $43^{\circ} 26^{\prime} 58.46^{\prime \prime}$ & $112^{\circ} 58^{\prime} 29.33^{\prime \prime}$ & $5,031.36$ & 2,495 & 1,218 & 432659112582601 \\
USGS 131A & $43^{\circ} 30^{\prime} 36.69^{\prime \prime}$ & $112^{\circ} 58^{\prime} 18.75^{\prime \prime}$ & $4,976.14$ & 2,475 & 1,198 & 433036112581800 \\
USGS 132 & $43^{\circ} 29^{\prime} 06.34^{\prime \prime}$ & $113^{\circ} 02^{\prime} 53.93^{\prime \prime}$ & $5,028.60$ & 2,540 & 1,238 & 432906113025000 \\
USGS 133 & $43^{\circ} 36^{\prime} 05.11^{\prime \prime}$ & $112^{\circ} 55^{\prime} 46.73^{\prime \prime}$ & $4,890.12$ & 3,960 & 818 & 433605112554300 \\
USGS 134 & $43^{\circ} 36^{\prime} 10.81^{\prime \prime}$ & $113^{\circ} 00^{\prime} 01.27^{\prime \prime}$ & $4,968.84$ & 3,960 & 949 & 433611112595800 \\
USGS 135 & $43^{\circ} 27^{\prime} 53.13^{\prime \prime}$ & $113^{\circ} 09^{\prime} 38.63^{\prime \prime}$ & $5,135.94$ & 2,675 & 1,198 & 432753113093600 \\
USGS 137A & $43^{\circ} 27^{\prime} 02.74^{\prime \prime}$ & $113^{\circ} 02^{\prime} 58.63^{\prime \prime}$ & $5,053.81$ & 2,580 & 1,058 & 432701113025800 \\
MIDDLE 2050A & $43^{\circ} 34^{\prime} 09.14^{\prime \prime}$ & $112^{\circ} 57^{\prime} 08.37^{\prime \prime}$ & $4,928.22$ & 3,790 & 1,427 & 433409112570500 \\
MIDDLE 2051 & $43^{\circ} 32^{\prime} 16.59^{\prime \prime}$ & $113^{\circ} 00^{\prime} 52.37^{\prime \prime}$ & $4,997.31$ & 3,270 & 1,179 & 433217113004900 \\
\hline
\end{tabular}

This report presents hydraulic head, water temperature, and water-chemistry results from data collected between calendar years 2014 to 2018 within 11 separate MLMS wells. MLMS wells are located throughout the INL (fig.1) and completed in the upper 250-700 ft of the eastern Snake River Plain aquifer at the INL. Normalized mean hydraulic head values were computed, graphed, and analyzed for MLMS data collected for the period of record from each well from all the sample ports. The sample ports were installed in zones of the aquifer that were highly transmissive of groundwater and that represented the water chemistry of the top three to five layers of the USGS INL groundwater model for steady-state and transient groundwater flow (Ackerman and others, 2010).

The list of constituents that were sampled from selected zones during 2014-18 was composed of tritium; gross alpha, beta and gamma radioactivity; and chloride, sodium, chromium, and nutrients (Bartholomay and others, 2014, appendix A, schedule 19). For the entire period of sampling, nine replicate samples and five field equipment blank samples were collected as a measure of quality assurance. Organic samples were collected from three wells near the RWMC to assess whether future sampling should occur and to evaluate tubing fluid contamination. Some water-quality trends of selected constituents were determined to evaluate long-term changes.

\section{Geohydrologic Setting}

The INL is located on the west-central part of the ESRP. The ESRP is a northeast-trending structural basin about 200 mi long and 50-70 mi wide (fig. 1). The basin, bounded by faults on the northwest and by downwarping and faulting on the southeast, has been filled with basaltic-lava flows that consist of olivine tholeiitic basaltic lava flows (about 85 percent by volume) with lesser amounts of interbedded fluvial and terrestrial sediments (Kuntz and others, 1992). The basaltic rocks and sedimentary deposits combine to form the ESRP aquifer, which is the primary source of groundwater on the plain. Significant landforms of the ESRP in the vicinity of the INL include (fig. 1) (1) rhyolite domes (Kuntz and others, 1994), (2) Big Lost Trough (Blair, 2002), (3) volcanic rift zones (VRZ), and (4) axial volcanic zone (AVZ). The Big Lost Trough (fig. 1) is bounded to the northwest by mountains and on the other sides by informally named volcanic rift zonesthe AVZ extends northeast and southwest and the Arco-Big Southern Butte VRZ extends northwest and southeast. The VRZs, including the Arco-Big Southern Butte VRZ and AVZ, are areas of focused volcanism resulting in high concentrations of volcanic vents and fissures (Anderson and others, 1999, p. 13; Hughes and others, 1999, p. 145), which are the major sources of basaltic rocks on the plain. 
$\boldsymbol{A}$

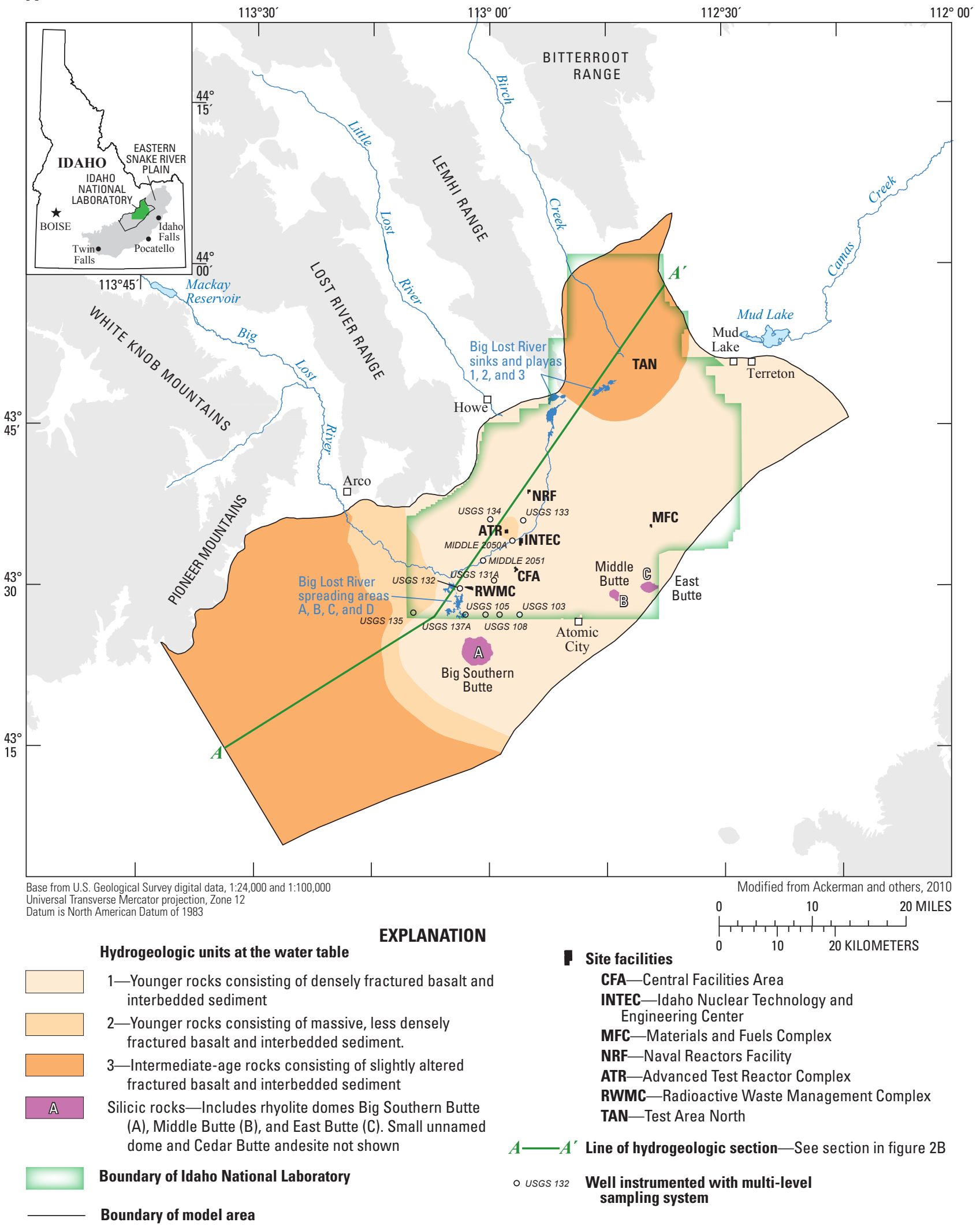

Figure 2. Distribution of hydrogeologic units at the water table $(A)$, and cross section showing well depth in relation to model layers and hydrogeologic units along section $A-A^{\prime}(B)$, Idaho National Laboratory and vicinity, Idaho. 


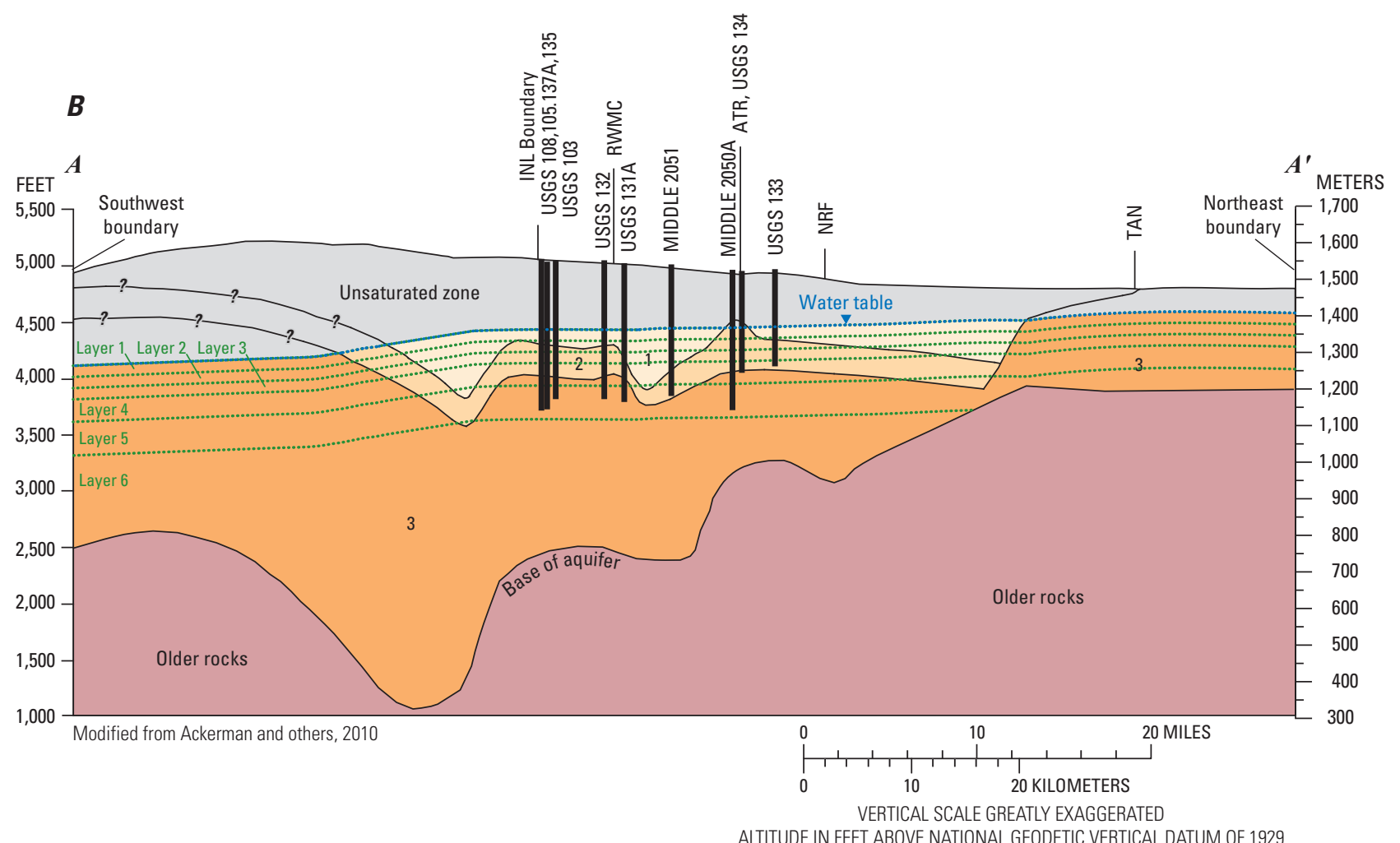

Hydrogeologic units

EXPLANATION

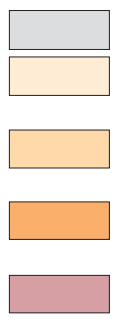

Unsaturated zone

1 -Younger rocks consisting of densely fractured basalt and interbedded sediment.

2-Younger rocks consisting of massive, less densely fractured basalt and interbedded sediment. Queried where uncertain. 3-Intermediate-age rocks consisting of slightly altered fractured basalt
and sediment.

Older rocks

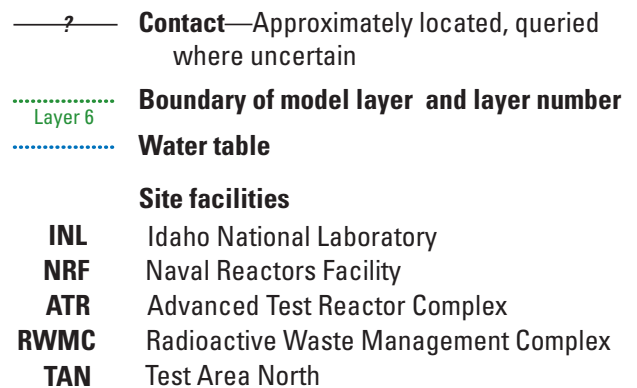

TAN

Wells USGS 103, 105, 108, 137A and 135 not projected perpendicular to cross-section trace; well depth based on total depth of well.

Figure 2.-Continued

The Big Lost River (BLR) has been a major source of sediment since late Pliocene time, resulting in a depocenter known as the Big Lost Trough (fig. 1; Geslin and others, 2002). Boreholes drilled in the Big Lost Trough generally encounter greater amounts by volume of interbedded sediment than boreholes drilled in and near the Arco-Big Southern Butte VRZ and AVZ (Anderson and others, 1999, fig. 9, table 2; Hughes and others, 2002; Welhan and others, 2007). Interbedded sediments penetrated by boreholes on the INL range in thickness from equal to or less than $1 \mathrm{ft}$ to equal to or greater than $313 \mathrm{ft}$ and are thickest in the northwestern part of the INL (Anderson and others, 1996; Welhan and others, 2007).
The ESRP aquifer is one of the most productive aquifers in the United States (U.S. Geological Survey, 1985, p. 193). The ESRP aquifer is recharged principally from infiltration of applied irrigation water, infiltration of streamflow, groundwater inflow from adjoining mountain drainage basins, and infiltration of precipitation. Water in the aquifer generally moves from northeast to southwest, and eventually discharges to springs along the Snake River downstream of Twin Falls, Idaho, about $100 \mathrm{mi}$ southwest of the INL. Water moves horizontally through basalt interflow zones and vertically through joints and interfingering edges of interflow zones. Infiltration of surface water, heavy pumpage, geologic conditions, and seasonal fluxes of recharge and discharge locally affect the movement of groundwater (Garabedian, 1986). 
At the INL, depth to water in wells completed in the ESRP aquifer ranges from about $200 \mathrm{ft}$ in the northern part of the site to more than $900 \mathrm{ft}$ in its southeastern part (Bartholomay and others, 2020). A substantial proportion of the groundwater moves through the upper 200-800 ft of basaltic rocks (Mann, 1986, p. 21). Ackerman (1991, p. 30), Bartholomay and others (1997, table 3), and Twining and Maimer (2019, table 2) reported a range of transmissivity of basalt in the upper part of the aquifer of $1.1-760,000 \mathrm{ft}^{2} / \mathrm{d}$. The hydraulic gradient at the INL ranges from 2 to $10 \mathrm{ft} / \mathrm{mi}$, with an average of $4 \mathrm{ft} / \mathrm{mi}$ (Bartholomay and others, 2020, fig. 9). Horizontal flow velocities of about $2-26 \mathrm{ft} / \mathrm{d}$ have been calculated based on the movement of various constituents in different areas of the aquifer at and near the INL (Robertson and others, 1974; Mann and Beasley, 1994; Cecil and others, 2000; Plummer and others, 2000; Busenberg and others, 2001). These flow rates equate to a travel time of 55-700 years for water beneath the INL to travel to springs that discharge at the terminus of the ESRP aquifer. Localized tracer tests at the INL have indicated vertical- and horizontal-transport rates as high as 60-150 ft/d (Nimmo and others, 2002; Duke and others, 2007).

\section{Previous Investigations}

Many investigations have evaluated the geology and hydrology of the ESRP aquifer at the INL. A comprehensive listing of publications by the USGS is available at https://www.usgs.gov/centers/id-water/science/publicationsidaho-national-laboratory?qt-science_center_objects $=0 \#$ qtscience_center_objects. Fisher and Twining (2011) documented the use of MLMSs to examine head and temperature for six wells from 2007 to 2008. Additionally, they described the MLMS components and specified the installation process, drilling methods, geology, and geophysical logs for wells USGS 103, USGS 132, USGS 133, USGS 134, MIDDLE 2050A, and MIDDLE 2051. From 2009 to 2010, the MLMS head and temperature monitoring network increased to nine wells (Twining and Fisher, 2012), including construction and monitoring of wells USGS 105, USGS 108, and USGS 135 in addition to the six wells of Fisher and Twining (2011). Twining and Fisher (2012) documented the use of MLMSs to examine head and temperature for these nine wells, revisited methods used to construct head and temperature profiles, summarized data collected from 2009 through 2010, and outlined quality-assurance methods. Twining and Fisher (2015) documented the use of MLMSs to examine head and temperature changes from all 11 MLMS for data collected during 2011-13 and included construction information for wells USGS 131A and USGS 137A in addition to information on the previous nine MLMS wells.
Previous investigations of water chemistry at different depths in the ESRP aquifer at the INL were documented in Peckham (1959), Jones (1961), Olmsted (1962), Mann (1986), Mann and Cecil (1990), Fromm and others (1994), U.S. Department of Energy (2004, 2007, 2008), Bartholomay (2009), Bartholomay and Twining, (2010), Bartholomay (2013), Davis and others (2013), and Bartholomay and others $(2013,2015,2017)$. Bartholomay and others (2015) provided a more detailed summary of the water chemistry information presented in all of these reports except for Bartholomay and others (2017). Bartholomay and others (2017) presented water chemistry results from the 11 MLMS wells from 2012 to 2015 . A tracer study examining whether drilling fluids could remain in the MLMSs was done by Bartholomay and others (2013) and they found that the tracer moved out of the formation for most of the zones analyzed.

\section{Methods and Quality Assurance}

The Westbay ${ }^{\mathrm{TM}}$ Multiport (MP) System was selected for multilevel groundwater monitoring at the INL. This system consists of a series of packers, measurement ports, magnetic collars, and variable length sections of casing (fig. 3). The MLMS works to restore the initial pressure and chemical conditions in the well prior to drilling. The MLMS is completely enclosed with a bore plug at the bottom and casing sections, sealed with o-rings, which run the entire length of the well. Each casing joint is leak-proof tested during installation to form a continuous, rigid, sealed system that prevents water from getting in or out. However, if a leak occurs at any joint, hydraulic isolation between the groundwater in the formation and any water inside the casing is maintained because the tubes connect only at the ports (Parker and others, 2006). The modular construction and varying lengths of polyvinyl chloride (PVC) sections allow ports (and, therefore, monitoring intervals) to be placed at almost any desired depth within a hole, provided that the spacing between each interval is great enough to accommodate a sufficient seal.

The methods used to collect depth-discrete measurements of head and temperature were described by Fisher and Twining (2011) and Twining and Fisher (2012) along with methods to calculate pressure probe transducer depths. The methods used for water-sample collection were described in Bartholomay and Twining (2010) and Bartholomay and others (2015). Fisher and Twining (2011) described the modular MLMS components (MP38 compared to MP55), sampling probe, acquisition system, system dimensions, and MLMS installation. All data in this report are available in the U.S. Geological Survey National Water Information System (NWIS) (U.S. Geological Survey, 2020). 


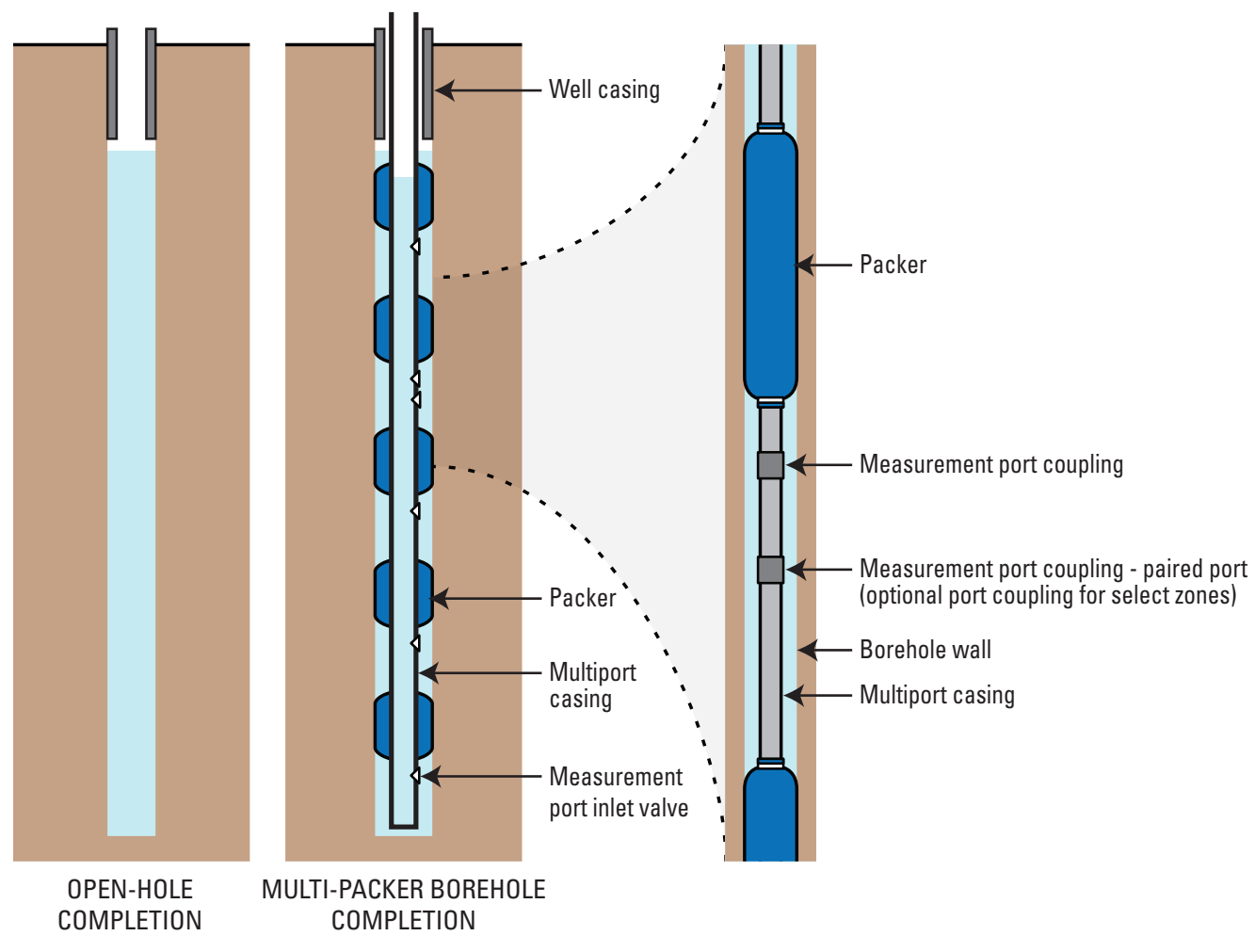

Modified from Fisher and Twining, 2011

Figure 3. Components of the Westbay ${ }^{\mathrm{TM}}$ Multiport System for multilevel groundwater monitoring.

A general summary and update to the methods for this report are included in the following report sections: (1) "Profiling and Completions," which describes the methods used to construct head and temperature profiles within a well; (2) "Data Processing," which describes the customized computer program, "MLMS"; (3) "Sample Collection," which describes the process for water-sample collection, the analytical methods used for analyses, and some guidelines for interpretation of analytical results; and (4) "Quality Assurance," which describes the accuracy and precision of head and temperature measurements along with interpretation of reproducibility and bias of the water samples collected.

\section{Profiling and Completions}

An individual head or temperature profile represents a set of measurements collected over a relatively short time period. The actual time required for each measurement period varied and was dependent on the quantity and spacing of ports within a MLMS. Profile measurements in this study were completed in less than 2 hours, a period considered nearly instantaneous when contrasted to the slower response times of groundwater systems.
Fluid pressure and temperature measurements were made using a portable sampling probe, a wireline-operated probe that is lowered into the multiport casing from the land surface and positioned at a selected measurement port coupling (fig. 4). The positioned probe was then coupled with the measurement port inlet valve to allow monitoring of groundwater outside the multiport casing and within the monitoring zone, so that groundwater in this zone was vertically isolated between upper and lower packers. Coupling the probe with the measurement port inlet valve was done by extending the backing shoe on the probe to create a hydraulic seal between the probe and the port and to open the port. Fluid pressure and temperature measurements were then transmitted to the land surface through the wireline communication cable, processed using a data acquisition system, and recorded on a datalogger. The head at each measurement port, assuming 100 percent barometric efficiency, was expressed as (Fisher and Twining, 2011):

$$
H=\Psi_{2}+Z-D=\left(\frac{P_{2}-P_{A t m}}{\gamma_{W}}\right) \times 144+Z-D,
$$




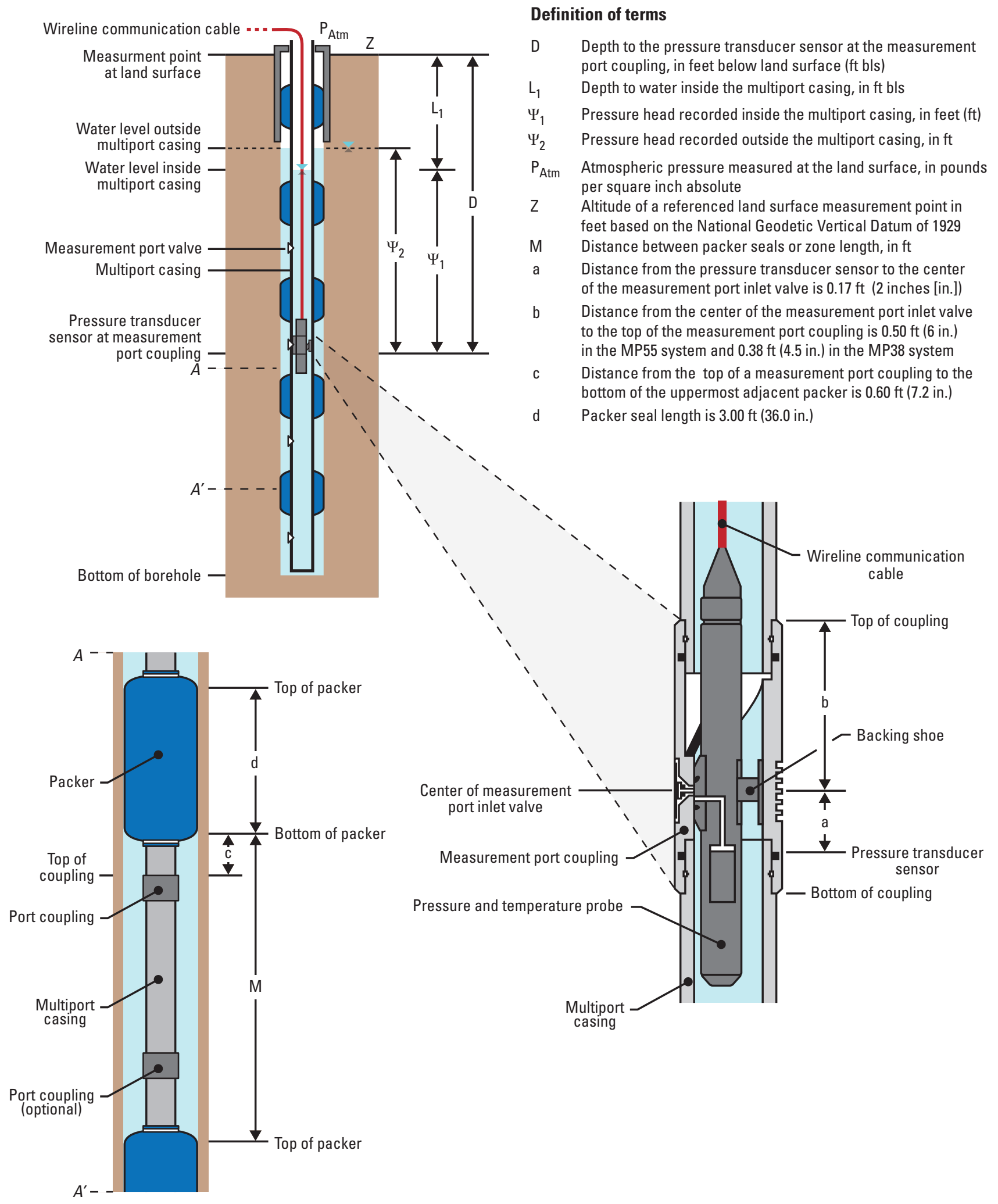

Modified from Fisher and Twining, 2011

Figure 4. Terms used in the calculation of hydraulic head based on the portable probe position when coupled with a measurement port in the multilevel monitoring system. 
where

$$
\begin{aligned}
& H \text { is the hydraulic head, in feet; } \\
& \Psi_{2} \quad \text { is the pressure head outside the multiport } \\
& \text { casing, in feet; } \\
& Z \quad \text { is the altitude of a referenced land-surface } \\
& \text { measurement point above the National } \\
& \text { Geodetic Vertical Datum of } 1929 \text { (NVGD } \\
& \text { 29), in feet; } \\
& D \quad \text { is the depth to the pressure transducer sensor } \\
& \text { at the measurement port coupling, in feet } \\
& \text { below land surface; } \\
& P_{2} \quad \text { is the fluid pressure measured outside the } \\
& \text { multiport casing in pounds per square inch } \\
& \text { absolute; } \\
& P_{\text {Atm }} \quad \text { is the atmospheric pressure measured at } \\
& \text { land surface, in pounds per square inch } \\
& \text { absolute; and } \\
& \gamma_{\mathrm{w}} \text { is the specific weight of water, in pounds per } \\
& \text { cubic foot. }
\end{aligned}
$$

Atmospheric pressure was monitored at the land surface using a handheld barometric sensor. The specific weight of water was calculated as a function of temperature only (McCutcheon and others, 1993), assuming negligible salinity and gravitational differences between measurements, and expressed as:

$$
\begin{aligned}
& \gamma_{\mathrm{w}}=62.42796 \times \\
& \left\{1-\left(\left[\frac{T+288.9414}{508929.2 \times(T+68.12963)}\right] \times(T-3.9863)^{2}\right)\right\}
\end{aligned}
$$

where

$$
\begin{gathered}
\gamma_{\mathrm{w}} \quad \text { is in units of pounds per cubic foot, and } \\
T \quad \text { is water temperature measured inside the } \\
\text { multiport casing from the bridge of the } \\
\text { pressure transducer in degrees Celsius. }
\end{gathered}
$$

The depth to the pressure transducer sensor at a port coupling was measured once (Fisher and Twining, 2011; Twining and Fisher, 2012, 2015) and calculated as:

$$
D=\Psi_{1}+L_{1}=\left(\frac{P_{1}-P_{\mathrm{Atm}}}{\gamma_{w}}\right) \times 144+L_{1},
$$

where

$D \quad$ is the depth to the pressure transducer, in feet below land surface;

$\Psi_{1} \quad$ is the pressure head inside the multiport casing, in feet;

$L_{1} \quad$ is the depth to water inside the multiport casing, in feet below land surface; and

$P_{1} \quad$ is the fluid pressure measured inside the multiport casing, in pounds per square inch absolute.
The depth to water inside the multiport casing $\left(L_{1}\right)$ was measured using an electronic measuring tape and corrected for borehole deviation (Fisher and Twining, 2011). Simultaneous measurements of $P_{1}, P_{\text {Atm }}$, and $L_{1}$ were made at each port coupling to account for (1) temporal changes in atmospheric conditions, and (2) depth to water that was dependent on the volume of water displaced by the wireline communication cable.

Multilevel completions included the location of measurement port valves, port couplings, packers, and monitoring zones in the well (where a monitoring zone describes the volumetric space between consecutive packers outside the multiport casing). The location of a multilevel component in a well is based on the measured depth to the pressure transducer at a port coupling (eq. 3) and its position within the MLMS installation log. For example, the length of a monitoring zone is defined as the distance between two consecutive packer seals and calculated by subtracting the depth at the bottom of the upper packer from the depth at the top of the lower packer, or:

$$
\begin{aligned}
& M_{z}=\left(D_{z-1}-a-b-c-d\right)- \\
& \left(D_{z}-a-b-c\right)=D_{z-1}-d-D_{z}
\end{aligned}
$$

where

$$
\begin{aligned}
& M_{z} \quad \text { is the distance between packer seals in } \\
& \text { monitoring zone } z \text {, in feet; } \\
& D_{z} \quad \text { is the depth to the pressure transducer sensor } \\
& \text { in the upper port coupling of zone } z \text {, in feet } \\
& \text { below land surface; } \\
& D_{z-1} \quad \text { is the depth to the pressure transducer sensor } \\
& \text { in the uppermost port coupling of zone } z-1 \text {, } \\
& \text { the zone located directly beneath zone } \mathrm{z} \text {, in } \\
& \text { feet below land surface; } \\
& a \quad \text { is the distance between the pressure } \\
& \text { transducer sensor and the center of the } \\
& \text { measurement port inlet valve, in feet, } 0.17 \\
& \text { feet in both MP systems; } \\
& b \quad \text { is the distance between the center of the } \\
& \text { measurement port inlet valve and the top } \\
& \text { of the measurement port coupling, in feet, } \\
& 0.50 \text { feet in the MP55 system and } 0.38 \text { feet } \\
& \text { in the MP38 system; } \\
& c \text { is the distance between the uppermost } \\
& \text { measurement port coupling and the bottom } \\
& \text { of the adjacent packer, in feet, } 0.60 \text { feet in } \\
& \text { both MP systems; and } \\
& d \quad \text { is the length of the inflated packer seal, in } \\
& \text { feet, } 3.00 \text { feet in both MP systems. }
\end{aligned}
$$

Parameters $a, b, c$, and $d$ were defined using nominal component lengths specified in the MLMS installation log (fig. 4); however, actual parameter lengths may vary because of component deformation in the multiport casing and $\gamma_{\mathrm{w}}$ port couplings that results from mechanical stretch and thermal expansion during MLMS installation. However, de-stressing 
during packer inflation was used to reduce the total strain on the system. Measurement errors associated with component deformation were assumed to be negligible because nominal component lengths were relatively small when compared to the measured depth to a pressure transducer $(D)$.

Standard procedures for collecting profile measurements were first described in Fisher and Twining (2011). The steps are summarized as follows: (1) The sampling probe is lowered to the deepest measurement port in the MLMS; (2) the probe is coupled with the monitoring port to continuously monitor fluid pressure and temperature; (3) measurements of fluid pressure, atmospheric pressure, and water temperature are recorded on a field sheet after temperature readings stabilize with fluctuations of less than $0.1^{\circ} \mathrm{C}$ (generally in 30 minutes or less); and (4) after fluid pressure and temperature measurements are recorded, the probe is decoupled from the port and raised to the next highest measurement port. The process is repeated until all ports are measured and final measurements are recorded.

Measurements of hydraulic head are presented in feet above the National Geodetic Vertical Datum of 1929 (NGVD 29) as the reference datum. At the time of this report, the USGS was updating historical vertical datums from NGVD 29 to the current North American Vertical Datum of 1988 (NAVD 88); however, not all MLMS wells had current vertical datums. Furthermore, to keep measurements of hydraulic head consistent with previous reports, the authors determined that using NGVD 29 as the common datum would be the most appropriate course of action. Updates to the latitude and longitude were made to reflect the North American Datum of 1983 (NAD 83); see table 1.

\section{Data Processing}

Statistical and graphical analysis of head and temperature data was completed using a customized computer program, "MLMS" (R Development Core Team, 2014). The computer program was used to process field data collected from all 11 MLMS wells to streamline and make data analysis consistent. The program "MLMS" also was used to examine qualityassurance data for head and temperature measurements.

The software program "MLMS" consists of a series of processing functions that include mlms.export.R, mlms. import.R, mlms.plotParedPort.R, mlms.plotProfile.R, and mlms.process.R. In addition, the software program "MLMS" requires a separate file (Completions.mps) that contains well information for graphing and analysis. This file (Completions. mps) includes borehole identifier, units of measure, borehole location (latitude, longitude, and land-surface altitude), casing length, measurement point, borehole drilled depth, completion depth, drilled date, installation date, number of zones, zone number, zone top, zone bottom, measurement port number, and port depth.
Field measurements were collected electronically and recorded on paper forms using a standardized field sheet (Bartholomay and others, 2014, fig. 10). The electronically stored measurements for each well were copied to text file templates and processed using the customized software program "MLMS."

\section{Sample Collection}

Sample collection by the USGS at the INL generally followed guidelines established by the USGS that are documented in the USGS National Field Manual (U.S. Geological Survey, variously dated) and Bartholomay and others (2014). Water samples were collected from 11 wells each equipped with a dedicated MLMS. A list of sample port depths from sampling zones from the aquifer are shown in table 2, at back of report.

Samples were collected using precleaned, stainless-steel thief sampling bottles that were lowered to the zone to be sampled, connected to the sampling port, and filled with formation water. The stainless-steel bottles were then raised to the surface and emptied into a precleaned container; the water was then processed to fill appropriate bottles for analyses. Field measurements also were taken from the precleaned container for $\mathrm{pH}$, specific conductance, water temperature, and dissolved oxygen (table 3 , at back of report). The field measurements were consistent with other measurements taken at the INL with $\mathrm{pH}$ ranging from 7.5 to $8.2 \mathrm{pH}$ units; specific conductance ranging from 276 to 428 microsiemens per centimeter at 25 degrees Celsius $\left({ }^{\circ} \mathrm{C}\right)$; water temperature ranging from 10.9 to $16.4{ }^{\circ} \mathrm{C}$, and dissolved oxygen concentration ranging from 6.34 to $11.0 \mathrm{mg} / \mathrm{L}$ (table 3, at back of report). Sample bottles were cleaned between uses in each sample zone by washing them in a Liquinox ${ }^{\circledR}$ solution and rinsing them with deionized water.

Field processing of samples differed depending on the constituents for which analyses were requested. Samples analyzed by the USGS National Water Quality Laboratory (NWQL) were placed in containers and preserved in accordance with laboratory requirements specified by Timme (1995) and Bartholomay and others (2014, appendix A). Containers and preservatives used for this study were supplied by the NWQL and had undergone a rigorous quality-control procedure (Pritt, 1989, p. 75) to minimize sample contamination. Water samples requiring filtration were filtered through a disposable $0.45-\mu \mathrm{m}$ filter cartridge that had been pre-rinsed with at least $1 \mathrm{~L}$ of deionized water. Constituent concentrations obtained from analysis of the $0.45-\mu \mathrm{m}$ filtrate are referred to as "dissolved" concentrations in this report. Samples analyzed by the Radiological and Environmental Sciences Laboratory (RESL) at the INL were placed in containers and preserved in accordance with laboratory requirements specified by Bodnar and Percival (1982) and Bartholomay and others (2014, appendix A). 
Analytical methods used by the USGS NWQL for selected organic, inorganic, and radionuclide constituents are described by Goerlitz and Brown (1972), Thatcher and others (1977), Wershaw and others (1987), Fishman and Friedman (1989), Faires (1993), Fishman (1993), Rose and Schroeder (1995), and McCurdy and others (2008). A discussion of procedures used by the DOE RESL for the analysis of radionuclides in water is provided by Bodnar and Percival (1982), Sill and Sill (1994), and U.S. Department of Energy (1995).

Concentrations of radionuclides are reported with an estimated sample standard deviation, $s$, which is obtained by propagating sources of analytical uncertainty in measurements. McCurdy and others (2008) provided details on interpreting radiological data used by the USGS. The guidelines for interpreting analytical results are based on an extension of a method proposed by Currie (1984) and discussed in Bartholomay and others (2017). In this report, radionuclide concentrations less than $3 s$ are considered to be less than a "reporting level." The reporting level should not be confused with the analytical method detection limit, which is based on laboratory procedures.

Concentrations of inorganic and organic constituents are reported with reference to long term method detection levels, laboratory reporting levels, interim reporting levels or with reference to minimum reporting levels. A description of the various criteria used to report inorganic and organic constituents is found in Bartholomay and others (2017, p. 28).

Statistical methods used to produce trend graphs follow methods described in Davis and others (2015).

\section{Quality Assurance and Quality Control}

The accuracy and precision of MLMS head measurements within the ESRP aquifer were first quantified using methods documented in Fisher and Twining (2011) by accounting for the cumulative error of five variables in the hydraulic head equation (eq. 1). In summary, the cumulative error for all five variables for independent head readings is $\pm 2.3 \mathrm{ft}$; a value determined by summing measurement accuracies for fluid pressure head $( \pm 1.15 \mathrm{ft}$ ), atmospheric pressure head $( \pm 0.01 \mathrm{ft})$, land-surface altitude $( \pm 0.01 \mathrm{ft})$, and pressure transducer sensor depth $( \pm 1.17 \mathrm{ft})$ (Fisher and Twining, 2011). Many of the sources of measurement error are minimized when considering the differences between two closely spaced readings of head, where head values are monitored using the same pressure probe, at similar depths, and at similar water densities. Under these conditions, vertical head differences have much less error than the error associated with any single head measurement because some sources of error subtract and are equal to or nearly equal for adjacent port readings. Therefore, $\mathrm{a} \pm 0.1$ - $\mathrm{ft}$ measurement accuracy was assumed for vertical head differences (and gradients) calculated between adjacent monitoring zones (Fisher and Twining, 2011).
Calibration of the fluid pressure sensor was done by the probe manufacturer. Calibration corrections were not applied to fluid pressure measurements because of the relatively high specified accuracy of the reference pressure sensor at \pm 0.100 $\mathrm{lb} / \mathrm{in}^{2}$ ( or $\pm 0.23 \mathrm{ft}$ at $13{ }^{\circ} \mathrm{C}$ ), which is the average ambient temperature in these wells (Fisher and Twining, 2011). Discussion and results from previous calibration testing are available in Twining and Fisher (2015).

Measurement precision was examined for 9 of 11 MLMSs by comparing head values between paired-ports, with two measurement ports located in the same monitoring zone (figs. 4 and 5). The method describing this technique was first noted in Fisher and Twining (2011). Theoretically, the distribution of head within a monitoring zone should be uniform; therefore, any substantial head difference between paired-port measurements may indicate a malfunctioning measurement port, a well construction anomaly, or groundwater density variations because of differences in total dissolved solids. For 34 of 40 monitoring zones, paired-port mean head differences were small $(<0.10 \mathrm{ft})$ for head measurements taken from 2014 to 2018 (fig. 5; appendix 1). Five MLMS zones had pairedport mean head differences that exceeded $\pm 0.2 \mathrm{ft}$ : (1) USGS 103 (zone 9) head measurements ranged from 0.30 to 0.44 $\mathrm{ft}$; (2) USGS 108 (zone 4) head measurements ranged from -0.01 to $0.67 \mathrm{ft}$; (3) USGS 108 (zone 11) head measurements ranged from 0.90 to $1.04 \mathrm{ft}$; (4) USGS 131A (zone 12) head measurements ranged from 1.83 to $2.44 \mathrm{ft}$; and (5) USGS 134 (zone 15) head measurements ranged from 0.42 to $0.79 \mathrm{ft}$ (appendix 1).

Paired-point data from USGS 108 (zones 4 and 11) represent data from the only two zones inconsistent with previous analyses (Twining and Fisher 2012, 2015). USGS 108 (zone 4) has a suspected erroneous measurement taken on June 24, 2014; whereas the remainder of the measurements taken from 2015 to 2018 show minor paired-port head difference $(<0.1$ $\mathrm{ft})$. Compared to previous investigations, the paired-port data range for USGS 108 (zone 11) was markedly higher. However, USGS 108 (zone 11) falls within a cased section of the borehole that shows slotted perforations (Twining and Fisher, 2012). The paired-port head difference, reported for zone 11 in USGS 108, suggests that the perforated section is becoming partially plugged or that potential debris surrounds port 16 (table 2, at back of report).

Quality-assurance (QA) protocol applied to water samples were first described by Bartholomay and Twining (2010). The overall QA and detailed descriptions of internal quality-control (QC) practices used by the NWQL are provided by Friedman and Erdmann (1982), Jones (1987), and Pritt and Raese (1995). The overall QA and detailed descriptions of internal QC practices used by the RESL are provided in Bodnar and Percival (1982) and U.S. Department of Energy (1995). Water samples were collected in accordance with a QA plan for quality-of-water activities conducted by personnel assigned to the USGS INL project office (Bartholomay and others, 2014). Additional QA was assessed with QC replicates and blanks. Nine QC replicate samples were collected 


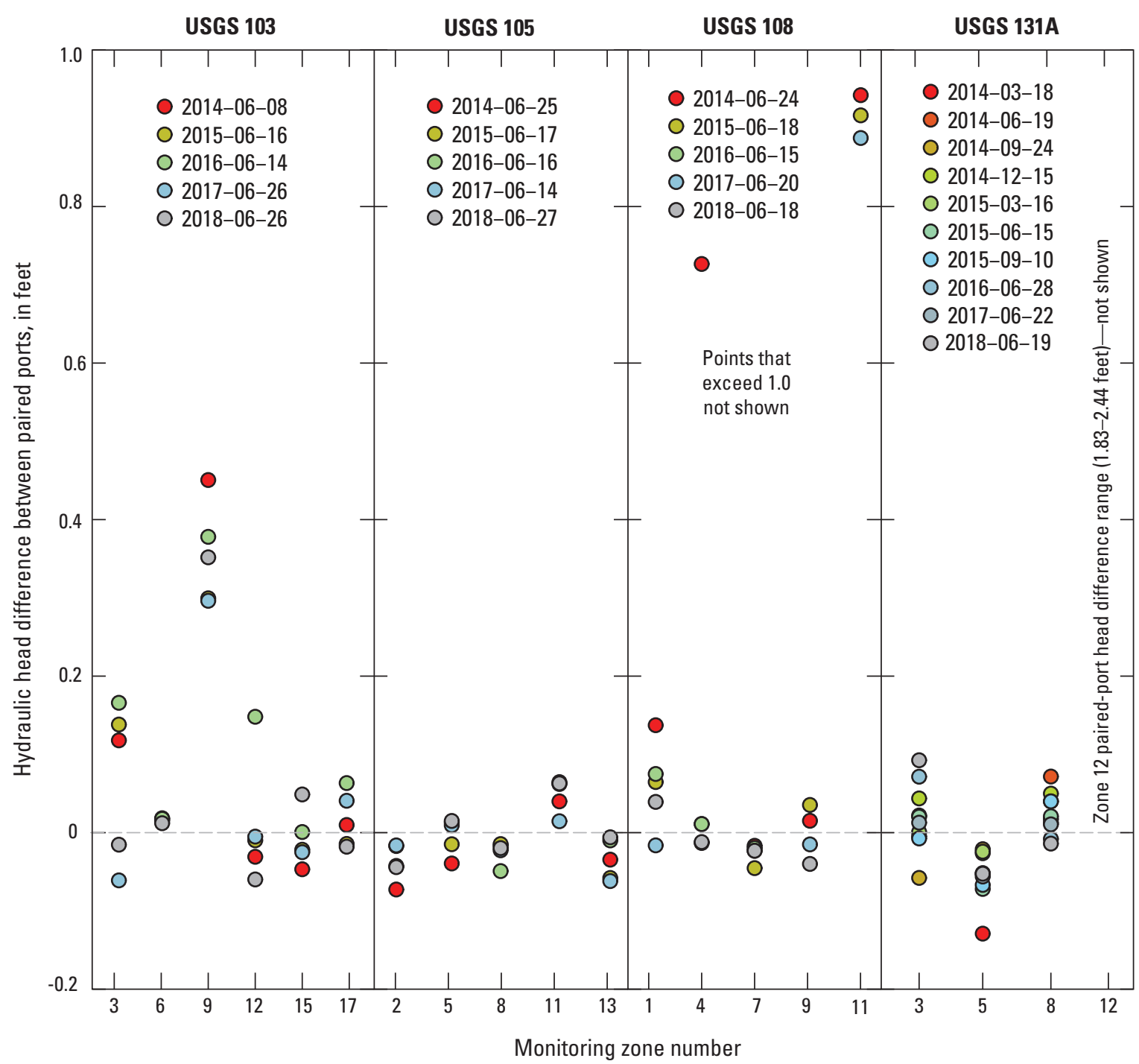

Figure 5. Hydraulic head differences between paired-ports and measurement ports in the same monitoring zone in wells U.S. Geological Survey (USGS) 103, USGS 105, USGS 108, USGS 131A, USGS 132, USGS 133, USGS 134, USGS 135, and USGS 137A, Idaho National Laboratory, Idaho, 2014-18.

during 2014-18; three field blanks were collected at wells MIDDLE 2050A and USGS 137A and consisted of distilled water from the USGS Idaho Falls Field Office. Two equipment blanks were collected at wells USGS 133 and MIDDLE 2051. Concentrations of major ions, nutrients, and chromium in blank samples were near or less than the reporting levels, suggesting no background contamination from field equipment or source water, except for one sample from USGS 137A for nutrient data. QAW-54 contained concentrations of nitrite plus nitrate and orthophosphate as phosphorus that seem to represent actual sample water from well USGS 137A; it is uncertain if the results were caused by field error or laboratory error.
If the uncertainty of the result is not readily available, which is often the case for most of the inorganic and organic constituents, the relative percent difference (RPD) can be used to compare equivalency of replicate pairs. The RPD is calculated based on the formula:

$$
R P D=((A B S(X 1-X 2)) /((X 1+X 2) / 2)) \times 100,
$$

where

$R P D \quad$ is the relative percent difference,

$A B S$ is the absolute value,

$X 1$ is the result for the primary environmental sample, and

$X 2$ is the result for the field-replicate sample. 


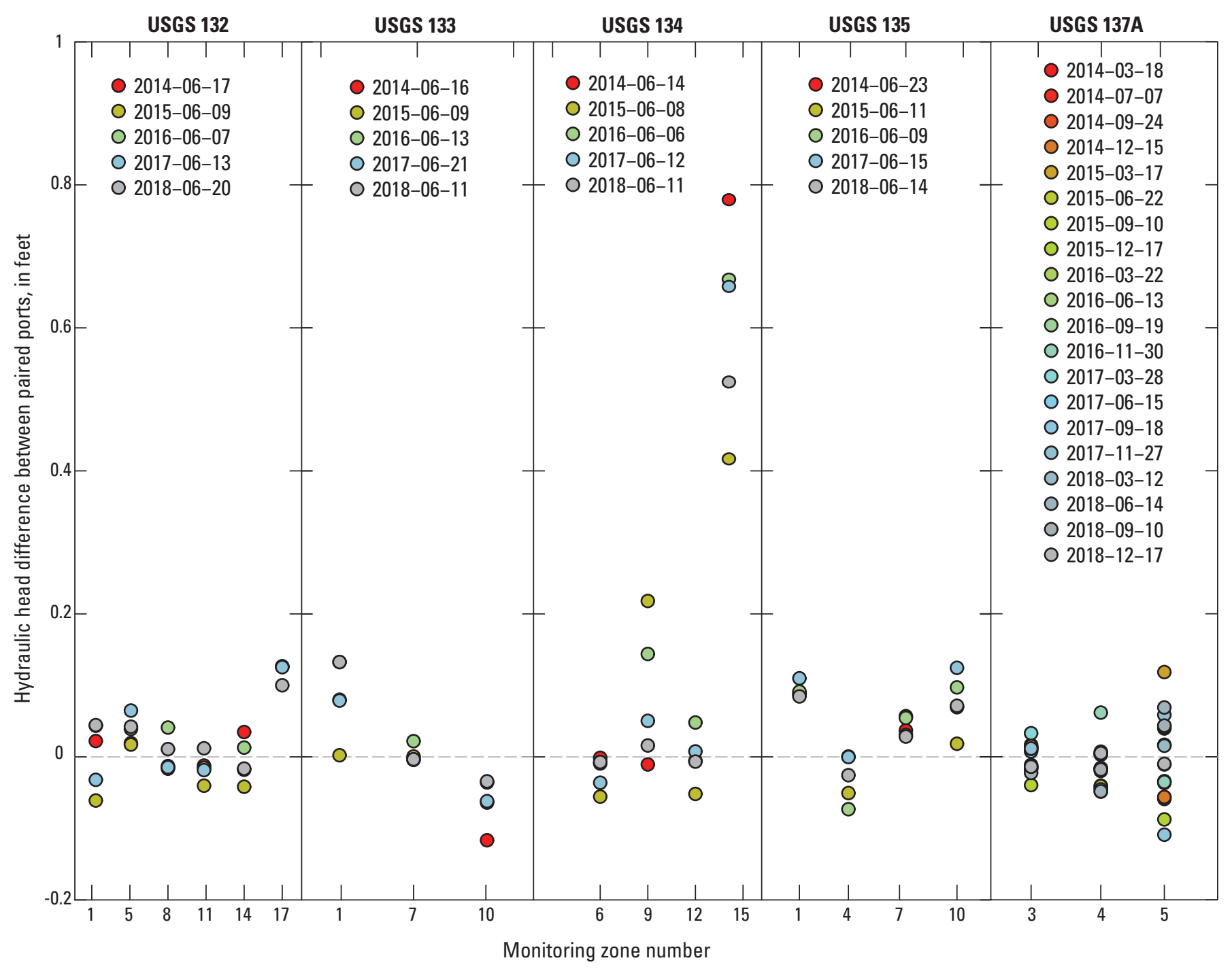

Figure 5.-Continued

A typical data-quality objective for field-replicate samples is a maximum RPD of 20 percent (Taylor, 1987). RPDs were less than 20 percent using equation 6 for 58 out of the 58 samples (100 percent) and can be considered statistically equivalent using this statistical test. Results of replicate samples generally indicated that the sample collection and laboratory procedures used were appropriate for the data obtained.

The statistical equivalency of radiochemical-constituent concentrations in sample replicate pairs was determined following a method defined by Volk (1969) and described in more detail by Williams (1996). In this method, statistical equivalence is determined within a specified confidence level. A value for the standard deviate, $Z$, is calculated, and then the level of significance of the result is evaluated (evaluation of the level of significance assumes that the sample population is distributed normally). For this report, concentrations of individual constituents in sample pairs (constituent pairs) were considered to be equivalent when the results were within two standard deviations of each other. At this confidence level (95-percent), the level of significance, determined from a standard normal probability curve, was 0.05 for a two-tailed test, and it corresponded to a Z-value of 1.96.

The equation used to determine $\mathrm{Z}$ was adapted from Volk (1969)

$$
Z=\frac{|x-y|}{\sqrt{\left(S_{x}\right)^{2}+\left(S_{y}\right)^{2}}},
$$

where

$x \quad$ is the concentration of a constituent in the routine sample,

$y \quad$ is the concentration of the same constituent in the sequential replicate sample,

$s_{x} \quad$ is the standard deviation of $x$, and

$s_{y} \quad$ is the standard deviation of $y$. 
When the population is not distributed normally, which is often the case with radiochemical results (L. DeWayne Cecil, U.S. Geological Survey, written commun., January 4, 2009), or an approximation of the standard deviation is used, a Z-value less than 1.96 must be considered as a guide when testing for equivalence. Constituent concentrations in sample pairs were considered to be statistically equivalent when the calculated Z-value was less than or equal to 1.96 .

The use of equation 5 , therefore, is considered to be a guide in determining if the results of radionuclide analyses of a replicate pair of samples were equivalent. The results and reported standard deviations for the analyses of replicate pairs and the $\mathrm{Z}$-values are provided in the concentration tables that are given later in this report. Z-values were less than 1.96 for 21 of the 24 replicate pairs ( 88 percent) and can be considered statistically equivalent. One replicate pair for gross alpha (QAW-44), and two replicate pairs for gross beta (QAW-44 and QAW-45) were not considered equivalent with this statistical test.

\section{Hydraulic Head and Temperature Measurements}

Head and temperature measurements were reported for the 11 MLMS wells for 2014-18 (fig. 1, table 1). Head and temperature measurements were recorded in 137 hydraulically isolated monitoring zones located 448.0-1,377.6 ft below land surface (bls) (table 2, at back of report). Detailed descriptions of geophysical logs, lithology logs, and completion logs for MLMS wells (USGS 103, USGS 105, USGS 108, USGS 131A, USGS 132, USGS 133, USGS 134, USGS 135, USGS 137A, MIDDLE 2050A, and MIDDLE 2051) are provided by Fisher and Twining (2011), Twining and Fisher (2012), and Twining and Fisher (2015).

\section{MLMS Measurements}

During the 2014-18 multilevel monitoring period, 105 profiles were collected and analyzed; these profiles represent individual annual and quarterly measurements of head and temperature from 11 MLMS wells (fig. 6; appendix 2). The MLMS profile schedule varied as follows: (1) Annual measurements were taken for MLMS wells USGS 103, USGS 105, USGS 108, USGS 132, USGS 133, USGS 134, and USGS 135; (2) quarterly measurements were taken for MLMS well USGS 131A during 2014 and into the third quarter of 2015 (September 2015), switching to annual measurements starting in 2016; and (3) quarterly measurements were taken for MLMS wells USGS 137A, MIDDLE 2050A, and MIDDLE 2051. Changes to the MLMS measurement schedule were based on profile consistency reported in Fisher and Twining (2011), Twining and Fisher (2012, 2015), and program changes.
Throughout the five-year monitoring period, the hydraulic head at all MLMS wells ranged from 4,415.5 to 4,462.6 ft at wells USGS 135 and USGS 133, respectively (fig.1; appendix 2). The lowest head values were measured in the farthest downgradient wells USGS 103, USGS 105, USGS 108, USGS 132, USGS 135, and USGS 137A (near the southern boundary); the highest head values were in the farthest upgradient wells USGS 133 and USGS 134 (fig. 1). Water temperature ranged from 10.4 to $16.8^{\circ} \mathrm{C}$ at wells MIDDLE 2051 and MIDDLE 2050A, respectively (fig. 6; appendix 2), which is within the reported range for temperatures measured in the ESRP aquifer at or near the INL-9.0-19.1 ${ }^{\circ} \mathrm{C}$ (Davis and others, 2013).

To quantify temporal variability in MLMS head and temperature between profile periods from 2014 to 2018, a Pearson correlation coefficient (PCC) was computed for each profile; methods used to compute PCCs are described in Fisher and Twining (2011). Computed PCCs ranged from -1 to 1 ; however, the closer the PCC is to either -1 or 1 , the stronger the correlation. To evaluate the correlation among all head or temperature profiles in a well requires the calculation of PCC for all permutations of profiles taken two at a time for each port, and the minimum of these values reflects the poorest correlation between profiles in a well. During the examination of individual head measurements and computation of PCC, seven suspected erroneous head measurements were identified and noted in the comment field in table 4 and are shown in figure 7. Erroneous measurements can occur if there is an inadequate face seal between the measurement probe and measurement port or if the port is blocked, resulting in an artificially lower PCC. Attempts were made to identify erroneous measurements; however, the suspected erroneous data were not removed from the PCC computation.

Profile data, plotted as individual measurements, reflect variability in head and temperature for all 11 MLMS wells (fig. 6). Profile data variability for individual MLMS measurements collected from 2014 to 2018 reflected variability similar to that of profile data collected during previous investigations (Fisher and Twining [2011], Twining and Fisher [2012, 2015]). Head and temperature data suggest that the general shape and variability reported for each MLMS profile have remained consistent year after year; however, some seasonal variability was measured in wells near the BLR. The BLR surface water was present in 2 of 5 years (2017-18) for data considered as part of this investigation (fig. 8). Increased head was measured in discrete zones representing the top $100 \mathrm{ft}$ of the aquifer starting in May 2017 in USGS wells MIDDLE 2050A and MIDDLE 2051 and was reflected in lowered PCC estimates as compared to years previously reported (table 4). For example, PCC estimates for hydraulic head reported for 2011-13 (Twining and Fisher, 2015) in MLMS wells MIDDLE 2050A and MIDDLE 2051 were 0.95 and 0.98 respectively. As expected, surface water from the BLR contributes to recharging the ESRP aquifer and MLMS well data suggest some localized mounding of water in wells near the BLR. 

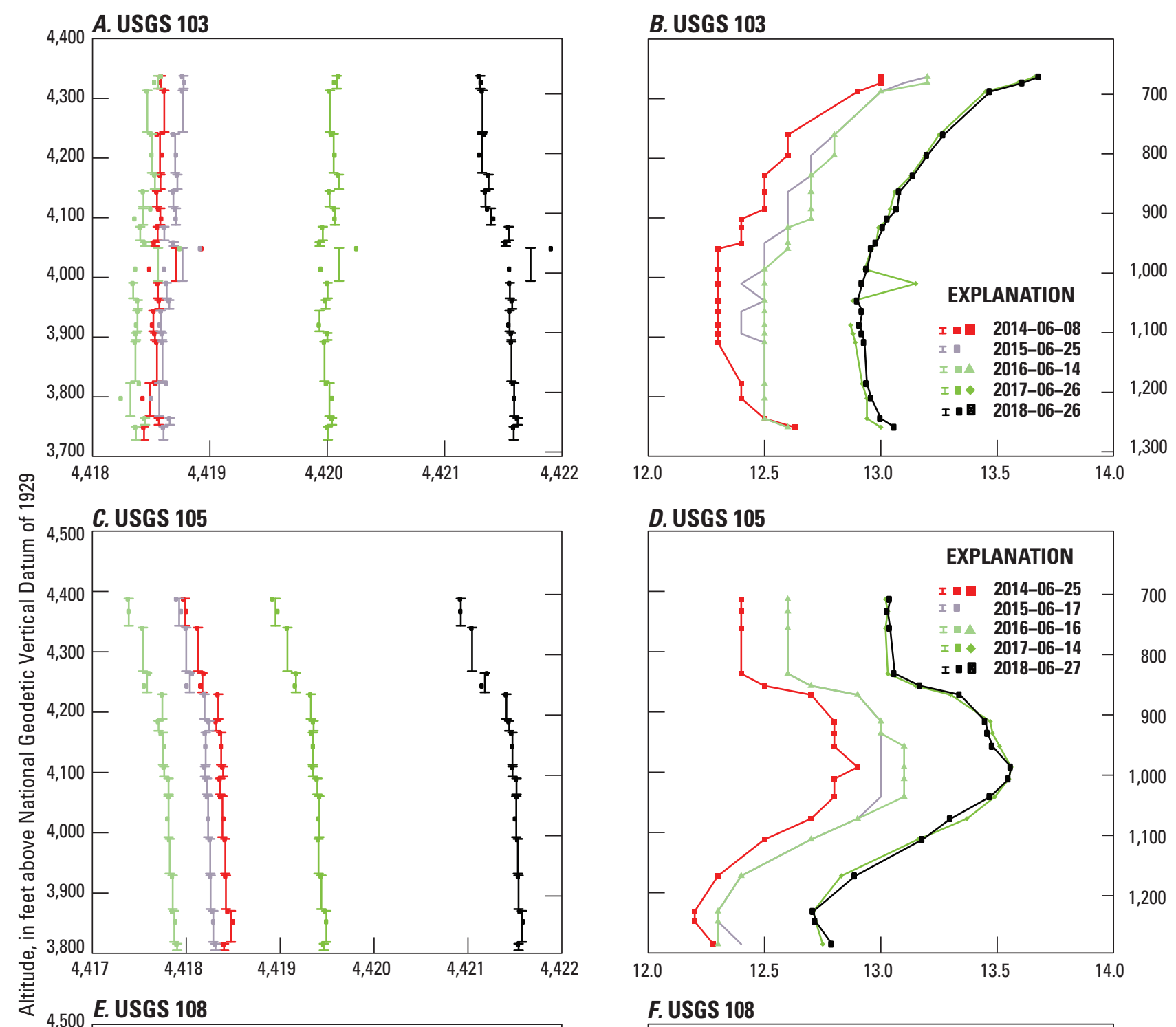

D. USGS 105
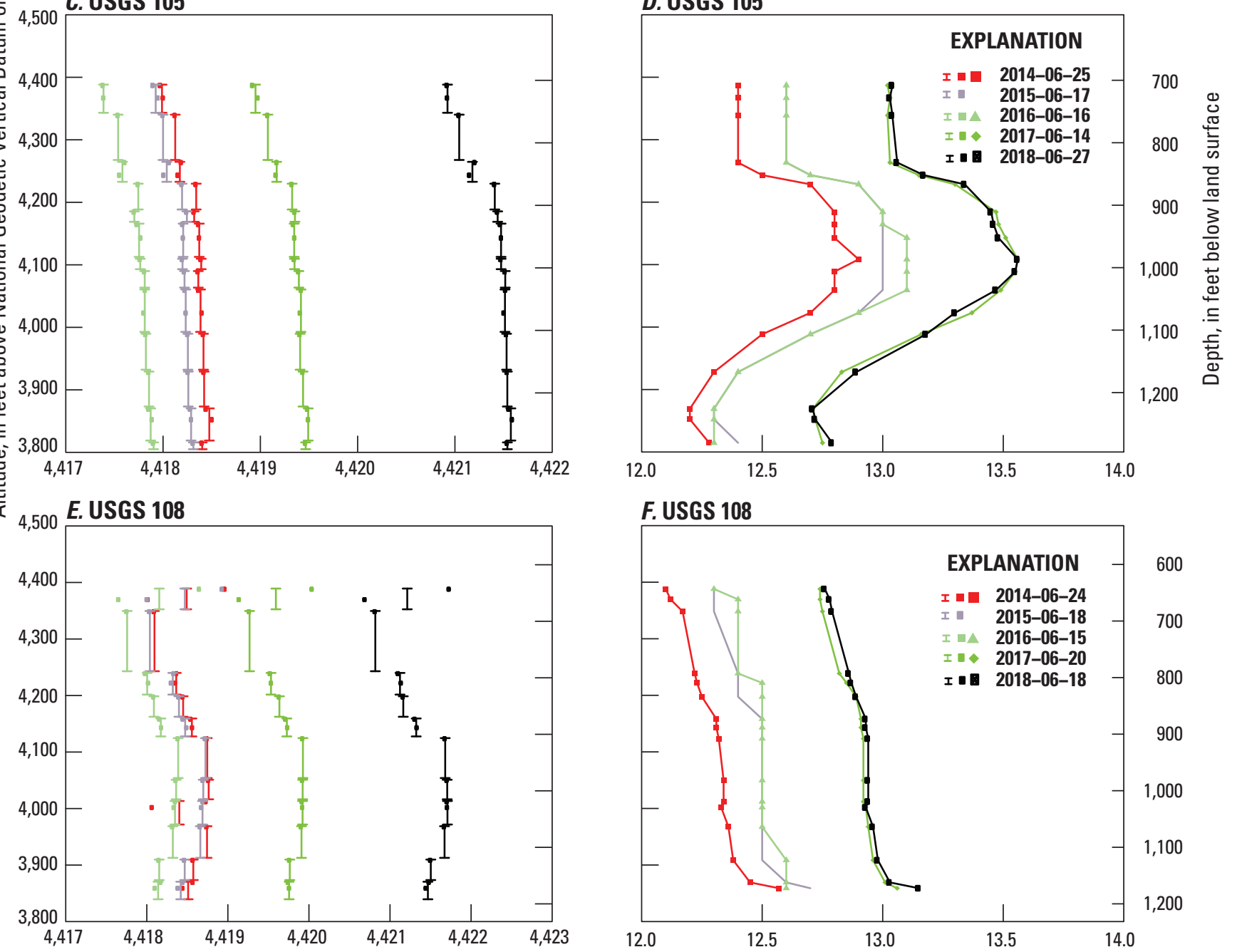

Altitude, in feet above National Geodetic Vertical Datum of 1929

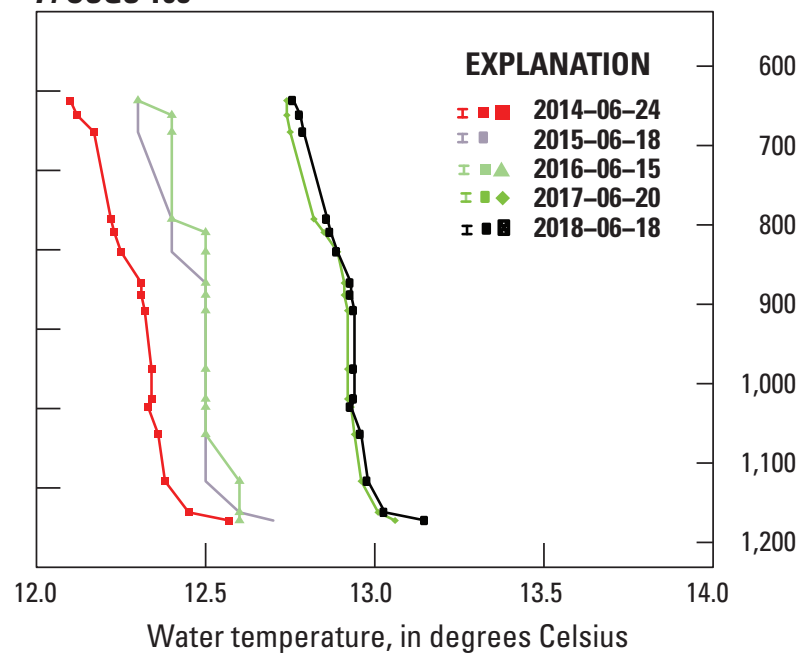

Figure 6. Hydraulic head differences between paired-ports and measurement ports in the same monitoring zone in wells U.S. Geological Survey (USGS) 103, USGS 105, USGS 108, USGS 131A, USGS 132, USGS 133, USGS 134, USGS 135, USGS 137A, MIDDLE 2050A, and MIDDLE 2051, Idaho National Laboratory, Idaho, 2014-18. 


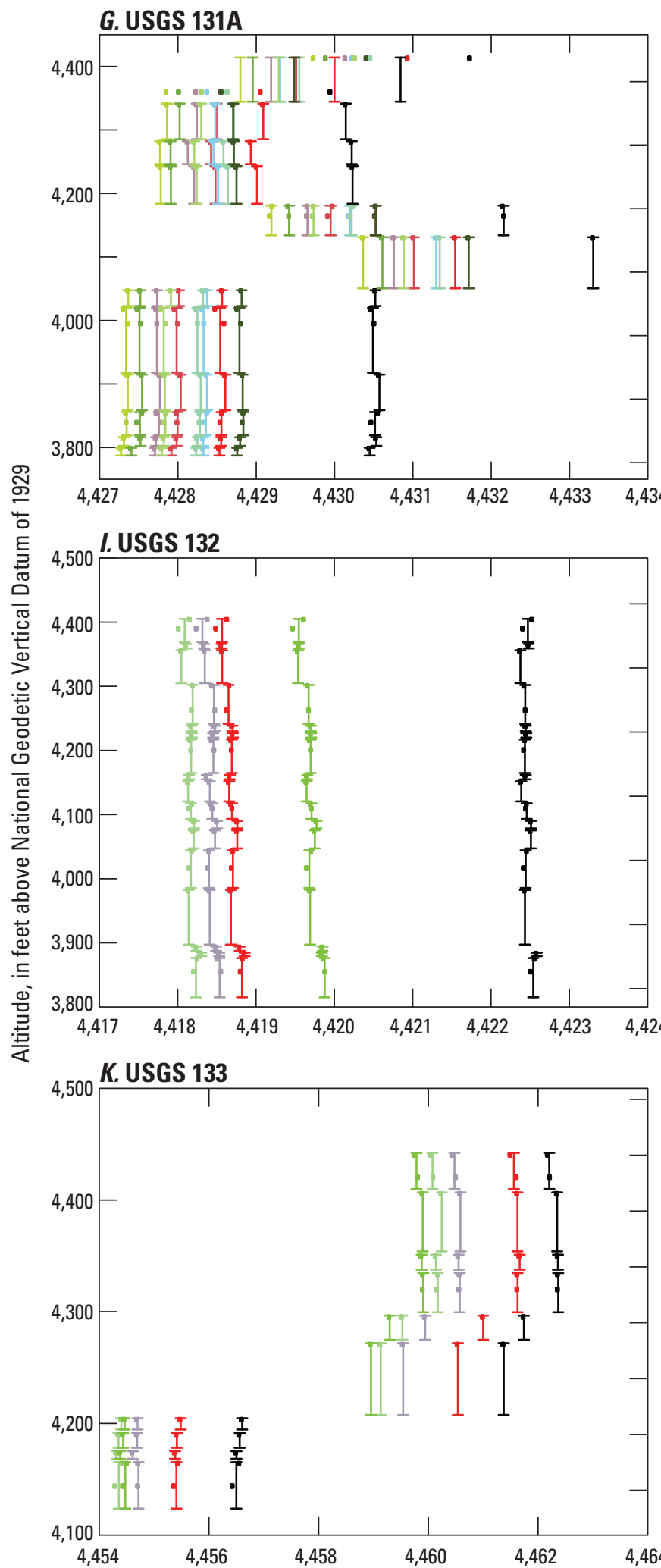

Altitude, in feet above National Geodetic Vertical Datum of 1929
H. USGS 131A

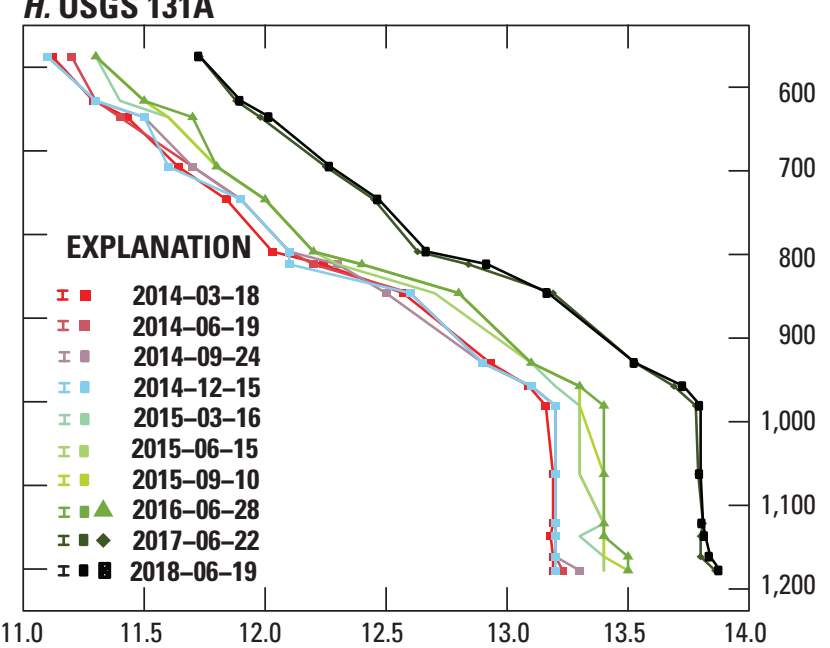

J. USGS 132

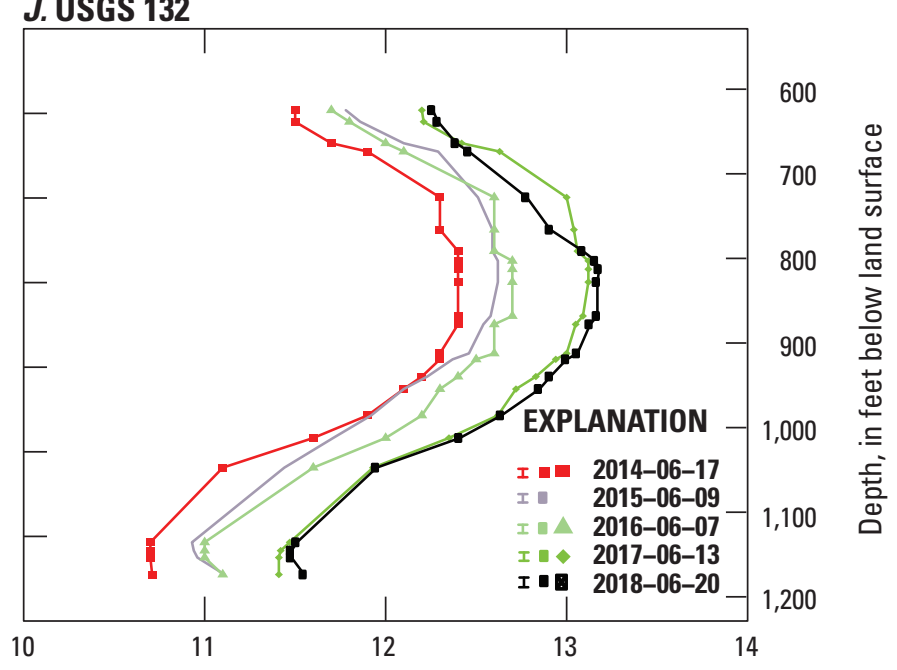

L. USGS 133

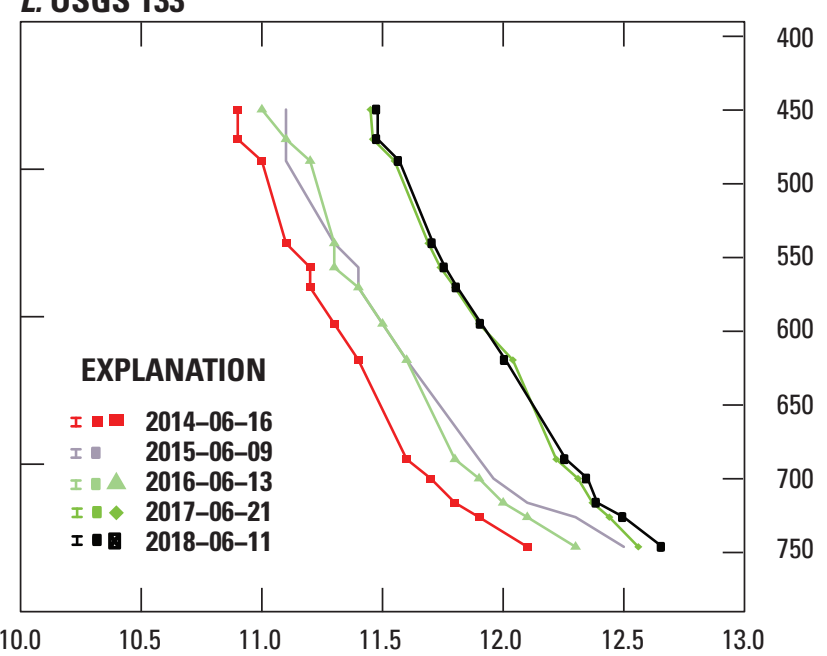

Water temperature, in degrees Celsius

Figure 6.-Continued 

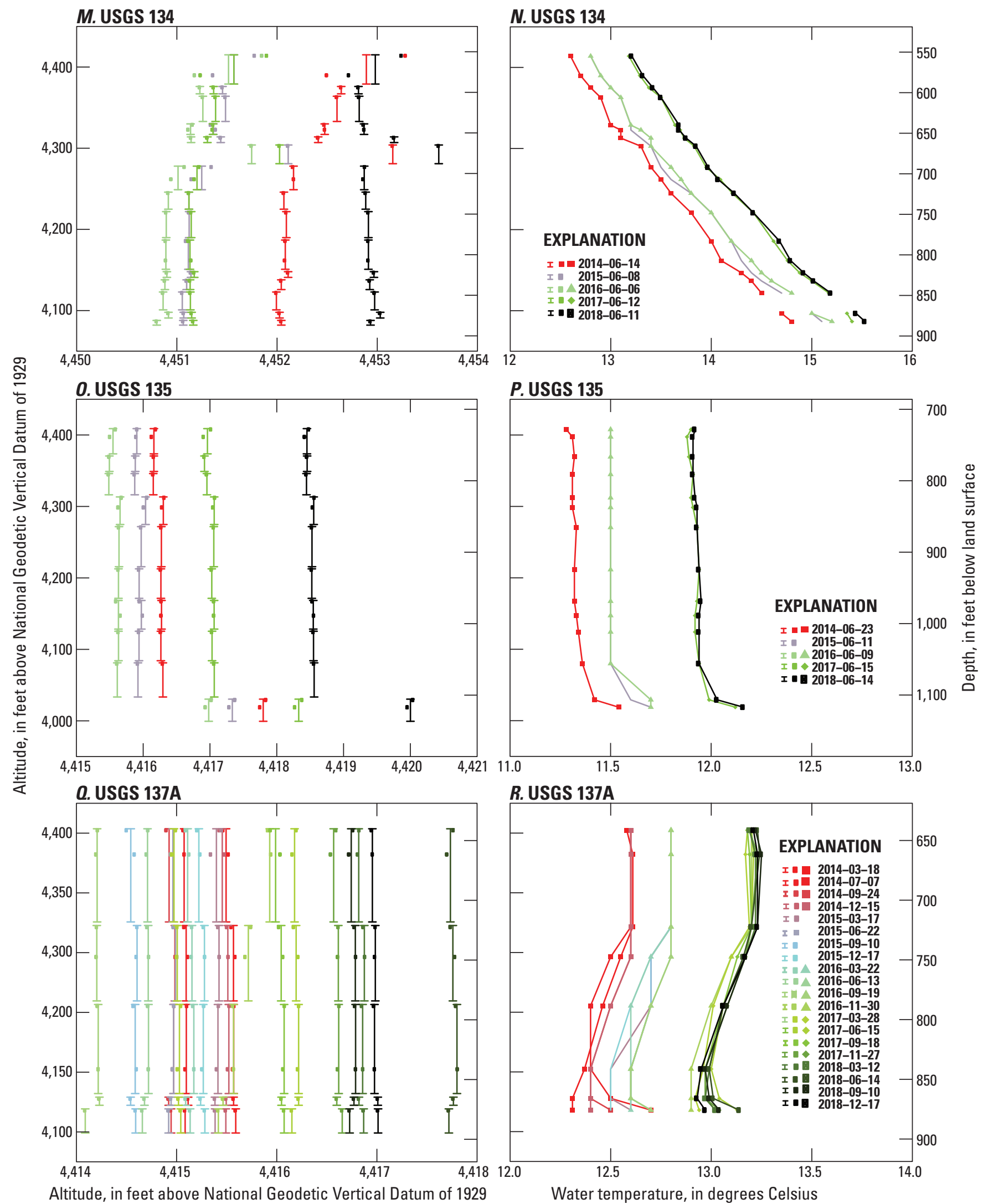

Figure 6.-Continued 


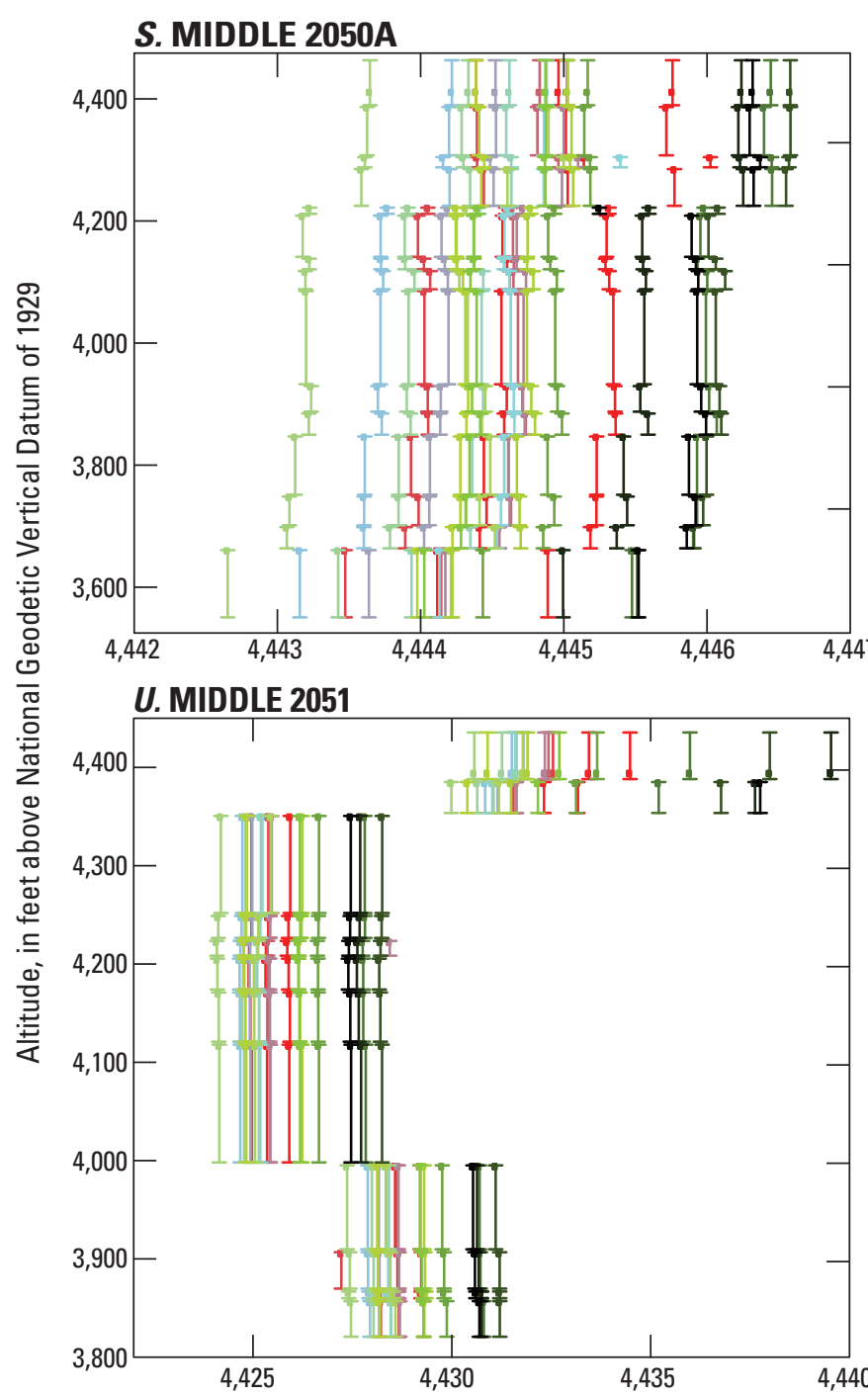

\section{T. MIDDLE 2050A}

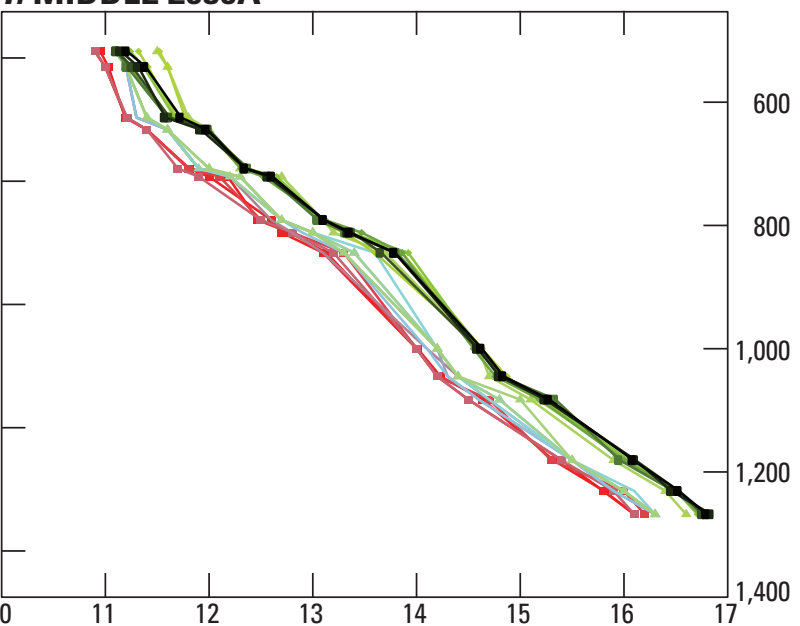

V. MIDDLE 2051

Altitude, in feet above National Geodetic Vertical Datum of 1929

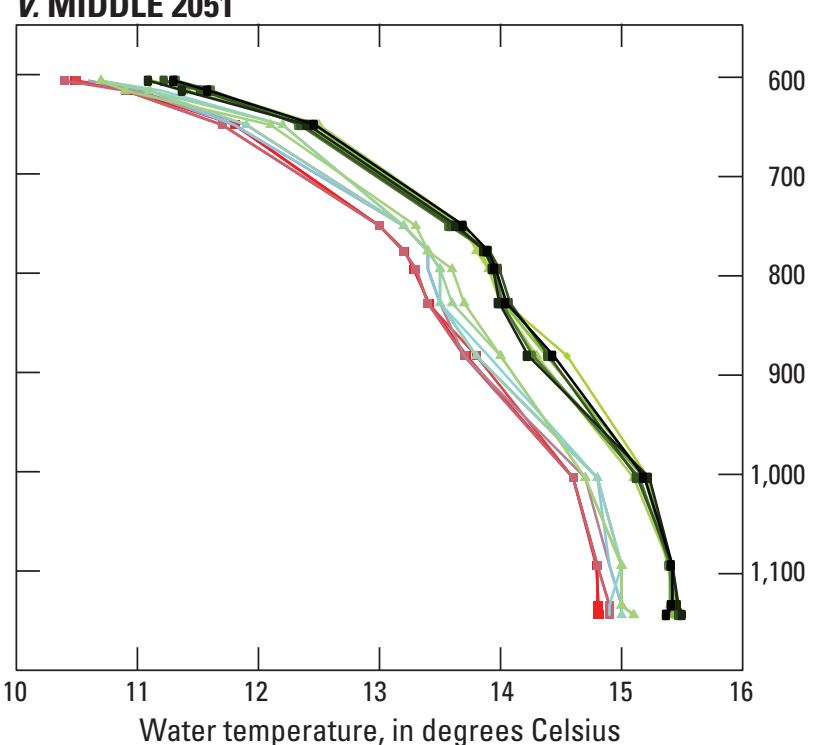

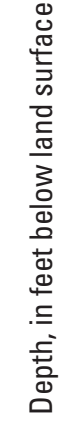

\section{EXPLANATION}

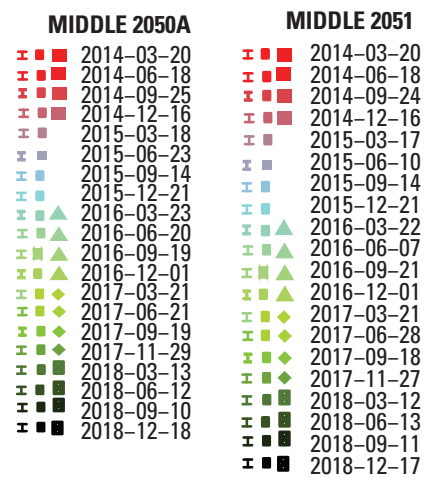

Figure 6. - Continued 
Table 4. Minimum Pearson correlation coefficients for hydraulic head and temperature profiles at selected wells, Idaho National Laboratory, Idaho, 2014-18.

[Local name: Local well identifier used in this study and shown in fig. 1. USGS, U.S. Geological Survey. Suspected erroneous data: Identified in fig. 7; measurements represent abnormal pressure readings that do not seem to reflect ambient pressure]

\begin{tabular}{lccl}
\hline \multirow{2}{*}{ Local name } & \multicolumn{2}{c}{$\begin{array}{c}\text { Minimum Pearson } \\
\text { correlation coefficient }\end{array}$} & \\
\cline { 2 - 3 } & $\begin{array}{c}\text { Hydraulic } \\
\text { head }\end{array}$ & Temperature & \\
\cline { 1 - 2 } USGS 103 & -0.13 & 0.92 & None \\
USGS 105 & 0.97 & 0.99 & None \\
USGS 108 & 0.73 & 0.86 & Head data taken on 06-24-14 (port 5) \\
USGS 131A & 0.90 & 1.00 & None \\
USGS 132 & 0.21 & 0.97 & Head data taken on 06-20-18 (port 4) \\
USGS 133 & 1.00 & 0.99 & None \\
USGS 134 & 0.56 & 0.99 & None \\
USGS 135 & 0.99 & 0.85 & None \\
USGS 137A & -0.86 & 0.17 & None \\
MIDDLE 2050A & 0.68 & 0.99 & Head data taken on 12-21-15 and 12-01-16 (port 13), and 12-18-18 (port 11) \\
MIDDLE 2051 & 0.91 & 0.99 & Head data taken on 09-24-14 (port 3) and 03-17-15 (port 8) \\
\hline
\end{tabular}

Minimum PCC values for head profiles ranged from -0.86 at well USGS 137 A to 1.00 at well USGS 133 (table 4). In four wells (USGS 103, USGS 108, USGS 132, and USGS 137A), the minimum PCC was less than 0.90 and is attributed to small vertical head differences and a relative uncertainty for head differences between adjacent zones of $\pm 0.1 \mathrm{ft}$. Under these circumstances, measurement error can produce a lower PCC even though a strong correlation exists (Twining and Fisher, 2015). MLMS well USGS 134 showed a minimum PCC of 0.56 , partly because of the head difference variation between ports in monitoring zones 14 and 15 and supported pressure response changes related to mountain front recharge events, as previously described in Fisher and Twining (2011), Twining and Fisher (2012), and Twining and Fisher (2015). MLMS well MIDDLE 2050A had a minimum PCC value of 0.68 , partly because of head difference related to seasonal variability between ports in upper monitoring zones (12-15), in addition to suspected erroneous readings (table 4, fig. 7). All other minimum PCC values were greater than or equal to 0.90 and suggest a strong positive correlation among head profiles.

Minimum PCC values for the temperature profiles ranged from 0.17 in MLMS well USGS 137A to 1.00 in MLMS well USGS 131A (table 4). The computed PCCs for most temperature profiles equaled or exceeded 0.92 and suggest a strong positive correlation among temperature profiles. However, three MLMS wells (USGS 108, USGS 135, and USGS 137A) had computed PCCs of less than 0.90 (table 4). The PCC computed for MLMS well USGS 108 suggests that the measured aquifer temperature was not allowed to fully equilibrate during certain profile periods, most visible during 2016, producing a lower PCC (fig. 6). For MLMS wells USGS 135 and USGS
$137 \mathrm{~A}$, the temperature range was about 0.2 and $0.3^{\circ} \mathrm{C}$, respectively. Under these circumstances a slight measurement error can produce a low PCC where a strong correlation exists.

\section{Well Profile Comparisons}

The methods used to describe the shape of individual head and temperature profiles along with major head inflections were first examined in Fisher and Twining (2011). Review of the MLMS data from 2014 to 2018 suggest that the general shape of individual head and temperature profiles has remained consistent between measurement events. This report does not present major head inflection data, where the general profile shape of MLMS head and temperature data remained mostly consistent from year to year; however, this report does consider measured ranges in data collected as part of this investigation and the last 10 years of normalized hydraulic head measurements and regional effects to the ESRP groundwater system.

The range in head and temperature data was examined between MLMS wells to better understand groundwater flow below the INL for aquifer intervals that ranged from 234 to $913 \mathrm{ft}$ (table 5). Head for a single profile event, considering all MLMS wells in this study, ranged from 0.1 to $16.3 \mathrm{ft}$ for MLMS wells USGS 137A and MIDDLE 2051, respectively; temperature for all MLMS wells ranged from 0.9 to $5.9{ }^{\circ} \mathrm{C}$ for MLMS wells USGS 135 and MIDDLE 2050A, respectively (table 5; appendix 2). Previously reported head ranged from 0.1 to $9.8 \mathrm{ft}$ for MLMS wells USGS 137A and MIDDLE 2051, respectively; previously reported temperature ranged from 0.2 to $5.3^{\circ} \mathrm{C}$ for MLMS wells USGS 135 and MIDDLE 2050A, respectively (Twining and Fisher, 2012). 


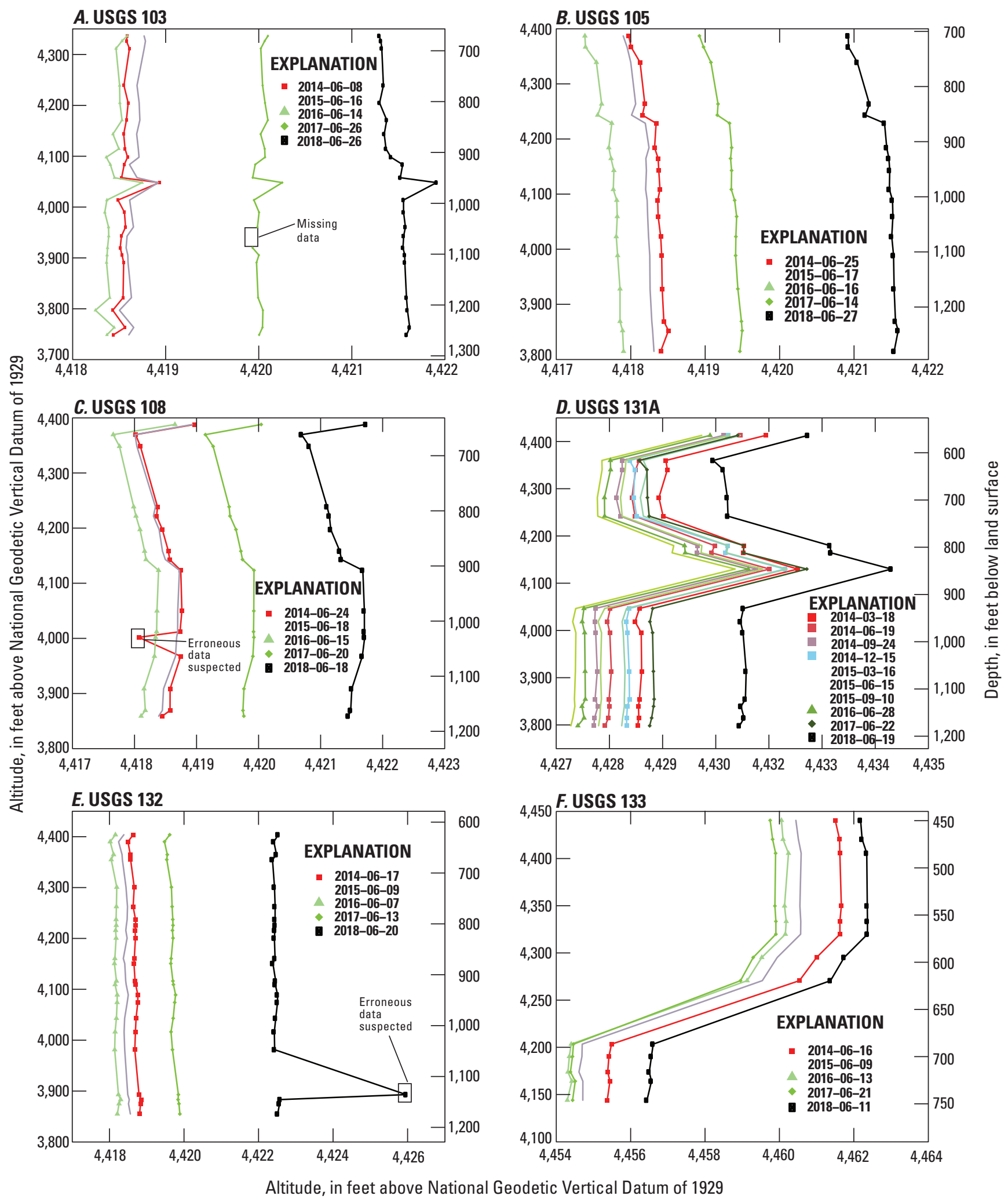

Figure 7. Individual hydraulic head measurements and suspected erroneous data taken at wells U.S. Geological Survey (USGS) 103, USGS 105, USGS 108, USGS 131A, USGS 132, USGS 133, USGS 134, USGS 135, USGS 137A, MIDDLE 2050A, and MIDDLE 2051, Idaho National Laboratory, Idaho, 2014-18. 

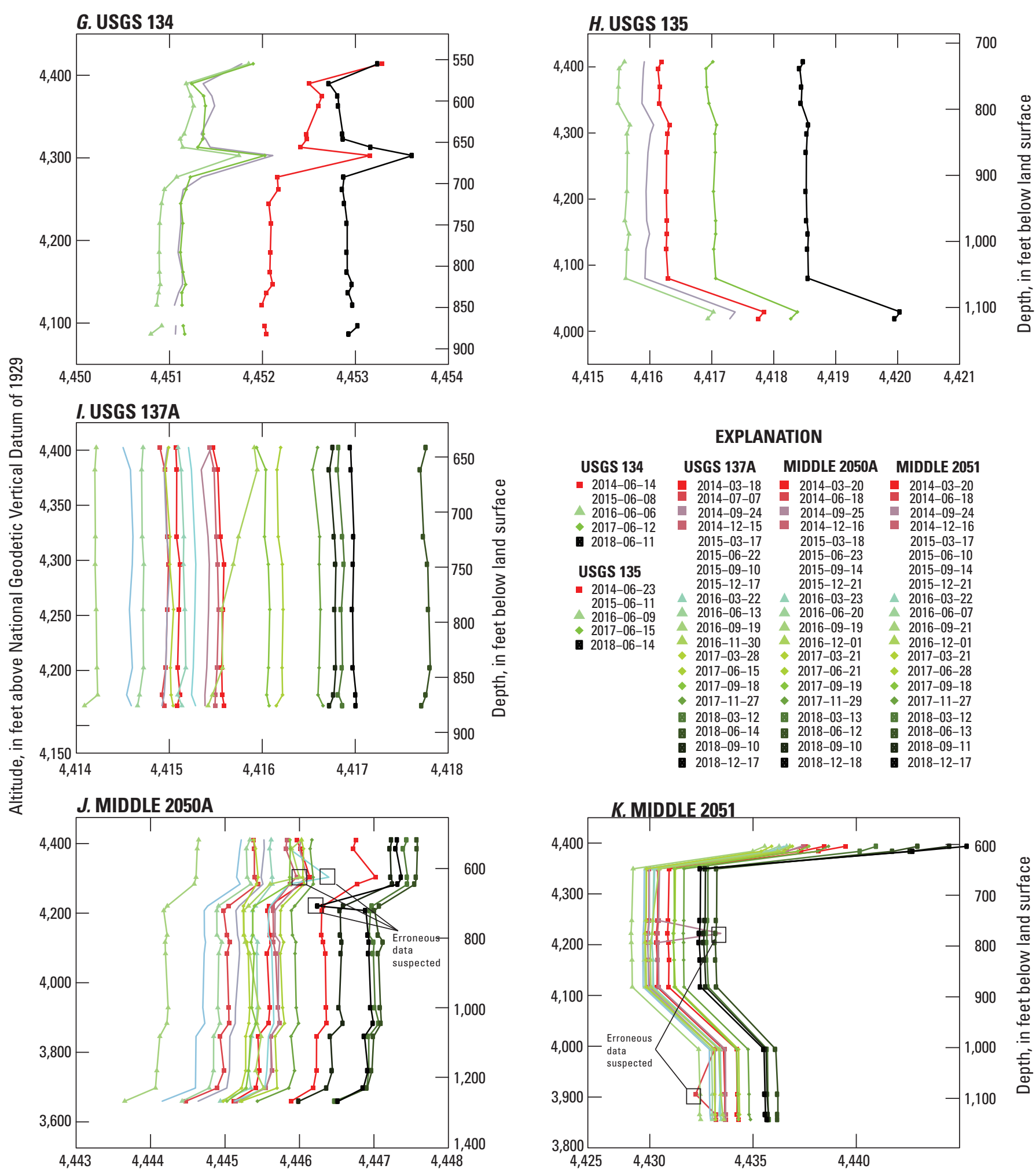

Altitude, in feet above National Geodetic Vertical Datum of 1929

Figure 7.-Continued 


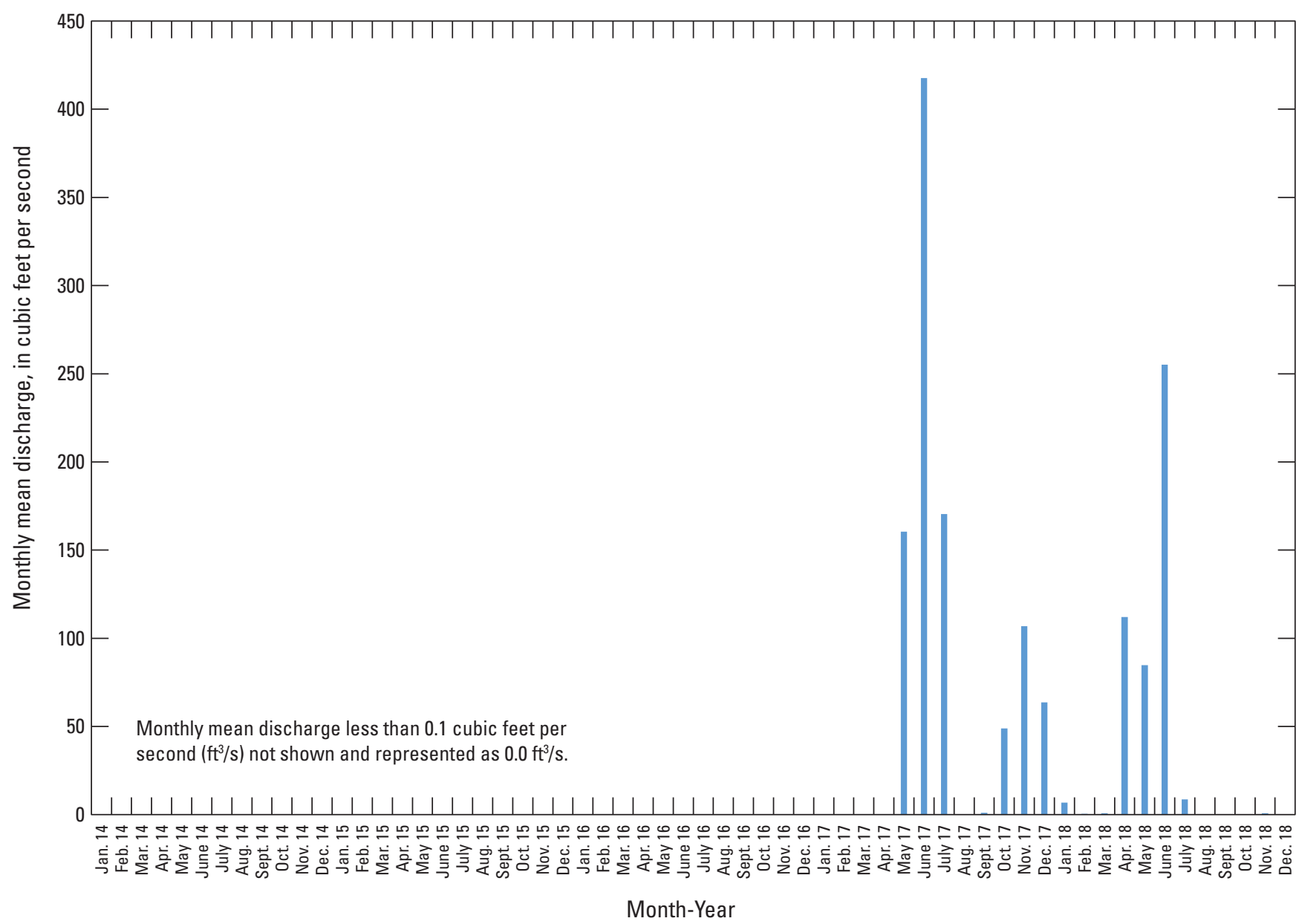

Figure 8. Big Lost River surface water flow measured at U.S. Geological Survey (USGS) streamgage 13132535, Big Lost River at Lincoln Boulevard Bridge, near Atomic City, Idaho National Laboratory, Idaho, January 2014-December 2018.

The temporal correlation among MLMSs was analyzed for new head data collected from 2014 to 2018, but also includes those previously reported going back to 2007 (Fisher and Twining 2011; Twining and Fisher, 2012, 2015), using the normalized mean head, $\widehat{H}$; these values of head were calculated for each MLMS and are expressed as follows (Fisher and Twining, 2011):

$$
\widehat{\bar{H}}_{t}=\frac{\bar{H}_{t}-\overline{\bar{H}}}{S} \quad \text { for } t=1, \ldots, n
$$

where

$\bar{H}_{t} \quad$ is the profile mean head for measurement event $t$, in feet, and defined as

$$
\bar{H}_{t}=\frac{1}{n} \sum_{i=1}^{n} H_{i} ;
$$

where

$n \quad$ is the total number of port head measurements in the MLMS borehole;

$H_{i} \quad$ is the head measurement at port $i$, in feet; and

$\bar{H} \quad$ is the mean of the profiles mean head values for all measurement events, in feet, and defined as

$$
\overline{\bar{H}}=\frac{1}{n} \sum_{i=1}^{n} \bar{H}_{i}
$$

and

$s \quad$ is the standard deviation of the profile mean head values for all measurement events, in feet, and defined as

$$
s=\sqrt{\frac{1}{n} \sum_{t=1}^{n}\left(H_{t}-\bar{H}\right)} .
$$




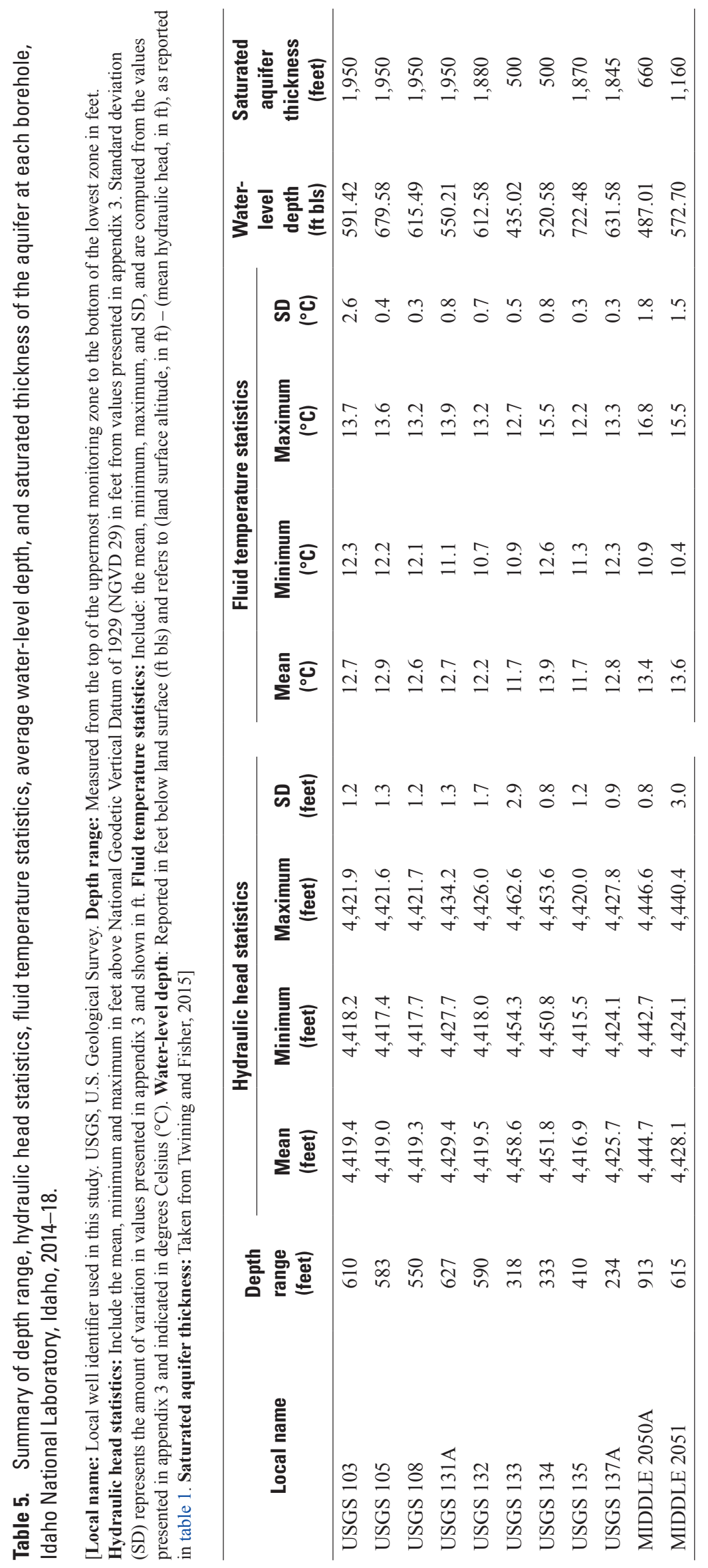


The values of $\widehat{H}$ for each of the 11 MLMS wells (fig. 9; appendix 3) suggest a moderate positive correlation among all MLMS wells, which reflects regional fluctuations in water levels in response to seasonality and location. For example, flow in the BLR that occurred during 2017 and 2018 (fig. 8) correlates to increased normalized mean total head for all MLMS wells (fig. 9).

Normalized mean head was examined for all 11 MLMS wells by location. Graphs of normalized mean total head include five MLMS wells that are located within the Big Lost Trough and six MLMS wells that are located within the AVZ and Arco-Big Southern Butte VRZ (figs. 1 and 9). Normalized mean head temporal correlations are stronger when the borehole locations are considered. For example, MLMS wells within the AVZ and Arco-Big Southern Butte VRZ (USGS 103, USGS 105, USGS 108, USGS 132, USGS 135, and USGS 137A, fig. 1) are completed in an area of highly permeable media and relatively large saturated thickness and show a positive temporal correlation (fig. 9A). Temporal correlation between MLMS wells completed in the Big Lost Trough generally is positive (fig. 9B). Subtle differences in temporal correlation can be attributed to frequency of measurements but also recharge from snowmelt or surface water flow in the BLR, or both (figs. 1, 8, and 9).
Groundwater temperature profiles for MLMS wells located along AVZ and Arco-Big Southern Butte VRZ (USGS 103, USGS 105, USGS 108, USGS 132, USGS 135, USGS 137A) mostly are dominated by convective heat transfer (fig. 1). Except for borehole USGS 132, MLMS temperature data vary between 0.9 to $1.4{ }^{\circ} \mathrm{C}$, suggesting a narrow temperature range over several hundred feet (table 5). As previously reported, interconnected fractures over several hundred feet of aquifer result in the vertical movement of groundwater as the aquifer thickens and as transmissivity increases along the southern boundary of the INL (Twining and Fisher, 2015).

Groundwater temperature profiles for MLMS wells located within the Big Lost Trough (USGS 131A, USGS 133, USGS 134, MIDDLE 2050A, MIDDLE 2051) mostly were dominated by conductive heat transfer and MLMS temperature data vary within a broader range $\left(1.8-5.9^{\circ} \mathrm{C}\right)$ compared to southern boundary MLMS wells (table 5). MLMS wells located within the Big Lost Trough generally were completed within a section of the ESRP aquifer that contain high percentages of fine-grained sediment (Twining and Fisher, 2015). Temperature trends in MLMS wells for 2014-18 were similar to those reported in Fisher and Twining (2011), Twining and Fisher (2012), and Twining and Fisher (2015), and suggest that groundwater temperature vertical profiles have remained stable. 


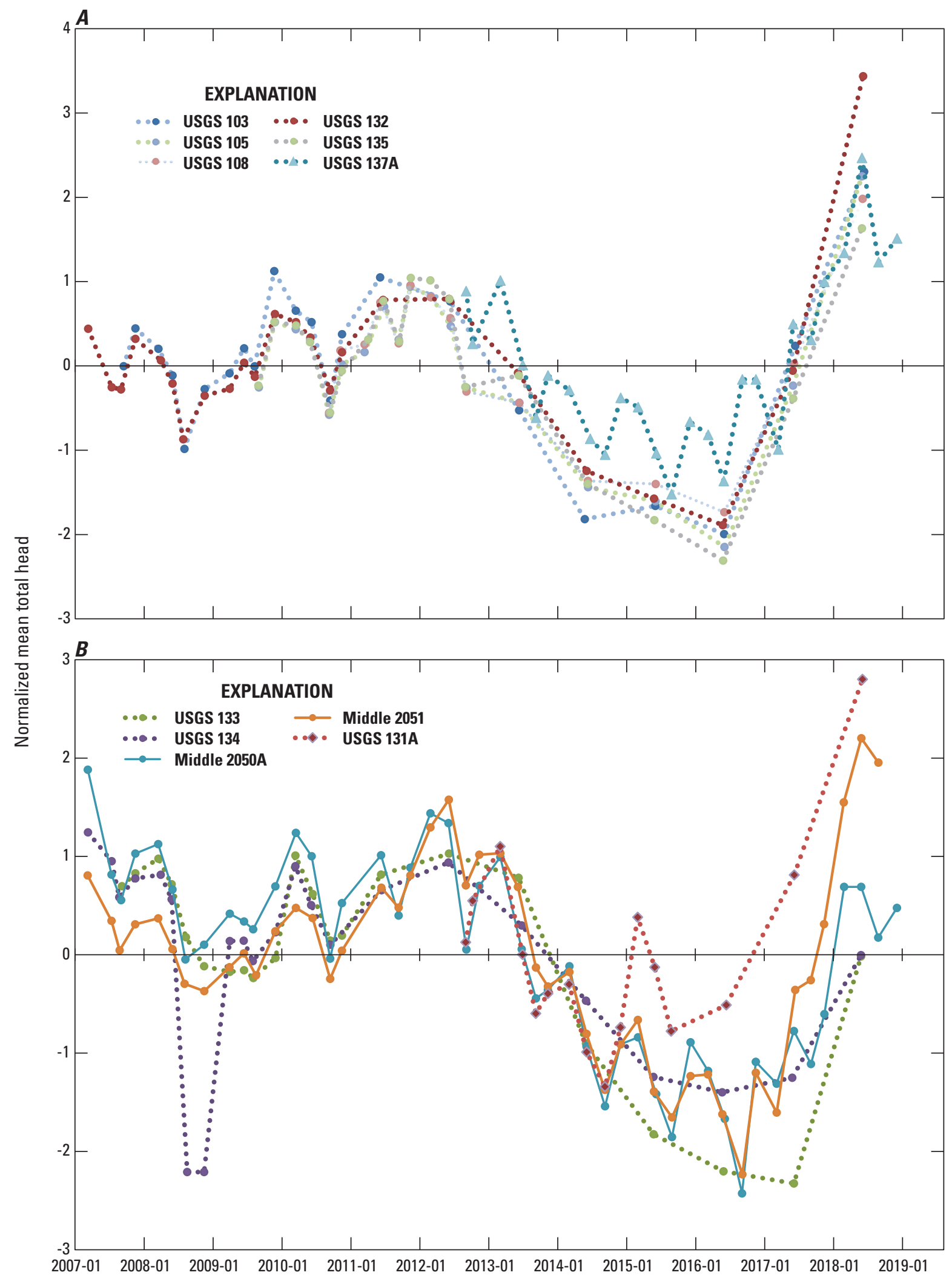

Figure 9. Quarterly values of the normalized mean hydraulic head at MLMS wells in $(A)$ the Axial Volcanic Zone and Arco-Big Southern Butte Volcanic Rift Zone (wells U.S. Geological Survey [USGS] 103, USGS 105, USGS 108, USGS 131A, and USGS 132), and (B) the Big Lost Trough (wells USGS 133, USGS 134, USGS 135, USGS 137A, MIDDLE 2050A, and MIDDLE 2051), Idaho National Laboratory, Idaho, 2007-18. 


\section{Chemical Constituents in the Eastern Snake River Plain Aquifer}

Water samples were analyzed for concentrations of chloride, chromium, sodium, sulfate, and nutrients by the NWQL from 22 select zones in 11 MLMS wells (tables 6 and 7, at back of report). Concentrations of gross alpha, gross beta, tritium, and cesium-137 were analyzed by the RESL (table 8, at back of report). Well MIDDLE 2051 (port 1) was sampled for a suite of water chemistry constituents in 2016 to determine whether the chemistry of water in the aquifer was changing (table 9, at back of report). Additionally, because of unexpected findings of tetrachloroethene from VOC sampling of well MIDDLE 2051 by the INL contractor Fluor (Forbes and Lawrence, 2018), the USGS collected additional samples from 15 zones from three MLMS wells (USGS 132, USGS 137A, and MIDDLE 2051) in 2016 and 2017, along with collecting VOC concentrations from tubing fluid from four MLMS wells (table 10, at back of report).

\section{Chloride}

Chloride has been discharged in wastewater at several facilities in the western part of the INL since 1952 and is still being discharged near the INTEC, ATR Complex, and NRF in infiltration ponds and ditches (fig. 1). The background chloride concentration in the water in the western part of the ESRP aquifer at the INL is about $12 \mathrm{mg} / \mathrm{L}$ (Bartholomay and Hall, 2016). For comparison to health criteria, the secondary maximum contaminant level (MCL) for drinking water is 250 mg/L (U.S. Environmental Protection Agency, 2019a). During 2014-18, concentrations of chloride for selected zones in all MLMS wells ranged from $4.2 \mathrm{mg} / \mathrm{L}$ in well MIDDLE 2050A (port 15) to $26.4 \mathrm{mg} / \mathrm{L}$ in well USGS 131A (port 10) (table 6, at back of report).

Chloride concentrations from water-quality samples collected from selected ports in well USGS 103 (ports 1, 3,7 , and 11) ranged from the background concentration of about $12.0 \mathrm{mg} / \mathrm{L}$ in port 11 to $14.6 \mathrm{mg} / \mathrm{L}$ in ports 1 and 7 and concentrations remain mostly consistent within discrete zones (table 6, at back of report). Chloride concentrations for well USGS 105 (ports 6, 10, and 14) showed similar concentrations with depth, ranging from 11.7 to $12.8 \mathrm{mg} / \mathrm{L}$ (table 6 , at back of report). Chloride concentrations for well USGS 108 (ports 1 and 12) have remained consistent for the period of sample record, with discrete zones having concentrations greater than the background concentration ranging from 16.1 (port 12) to $17.2 \mathrm{mg} / \mathrm{L}$ (port 1) (table 6, at back of report). Chloride concentrations for well USGS 131A (ports 3, 6, 10, and 15) ranged from 13.0 (port 6) to $26.4 \mathrm{mg} / \mathrm{L}$ (port 10), and chloride concentrations were much more elevated (by about $10 \mathrm{mg} / \mathrm{L})$ at port 10 when compared to other ports in well USGS 131A (table 6, at back of report). Chloride concentrations in well USGS 132 (port 18) have remained mostly consistent, with concentrations less than background levels, but one sample collected during 2018 was slightly greater than background at $12.3 \mathrm{mg} / \mathrm{L}$ (table 6 , at back of report). Wells USGS 133 (port 12), USGS 134 (port 19) and USGS 135 (port 9) had consistent chloride concentrations that were less than background levels, ranging from 6.7 to $11.9 \mathrm{mg} / \mathrm{L}$ (table 6, at back of report). Chloride concentrations for well USGS 137A ranged from 11.1 to $14.2 \mathrm{mg} / \mathrm{L}$ and decreased with increasing aquifer depth at this location (Bartholomay and others, 2015). Chloride concentrations in well USGS 137A were near the background concentration in the deeper ports (port 1,3 , and 5), and were slightly greater than the background concentration in the port near the top of the aquifer (port 7) (table 6, at back of report). Chloride concentrations in well MIDDLE 2050A (port 15) were variable, ranging from 4.2 to $12.5 \mathrm{mg} / \mathrm{L}$, and showed a statistically significant decreasing trend (fig. 10). Concentrations decreased substantially during years 2006, 2012, 2017, and 2018 (fig. 10), which suggests that chloride concentrations may be diluted during years in which flow occurred in the BLR (Bartholomay and others, 2020, fig. 8). Well MIDDLE 2051 (ports 1, 3, 6, and 9) had consistent chloride concentrations, ranging from 10.5 to 11.7 $\mathrm{mg} / \mathrm{L}$ (table 6, at back of report). Wells MIDDLE 2050A and MIDDLE 2051 are both adjacent to the BLR (fig. 1), but well MIDDLE 2050A only has samples from near the top of the aquifer and samples from well MIDDLE 2051 are only from ports deeper in the aquifer (table 6, at back of report). Based on the chloride data, surface water recharges mainly the upper unit of the aquifer and does not seem to affect deeper zones to the same extent.

\section{Chromium}

Chromium has been discharged in wastewater primarily at the ATR Complex in the past and was also discharged to the disposal well at the ATR Complex. Minor amounts of chromium also were discharged at the INTEC and the Power Burst Facility. The background chromium concentration in water in the western part of the ESRP aquifer at the INL is about $3 \mu \mathrm{g} / \mathrm{L}$ (Bartholomay and Hall, 2016). For comparison to health criteria, the MCL for drinking water is $100 \mu \mathrm{g} / \mathrm{L}$ (U.S. Environmental Protection Agency, 2019b). Concentrations of chromium for selected zones in all MLMS wells ranged from $0.86 \mu \mathrm{g} / \mathrm{L}$ in well MIDDLE 2050A (port 15) to $10.9 \mu \mathrm{g} / \mathrm{L}$ in well USGS 131A (port 10) (table 6, at back of report). 

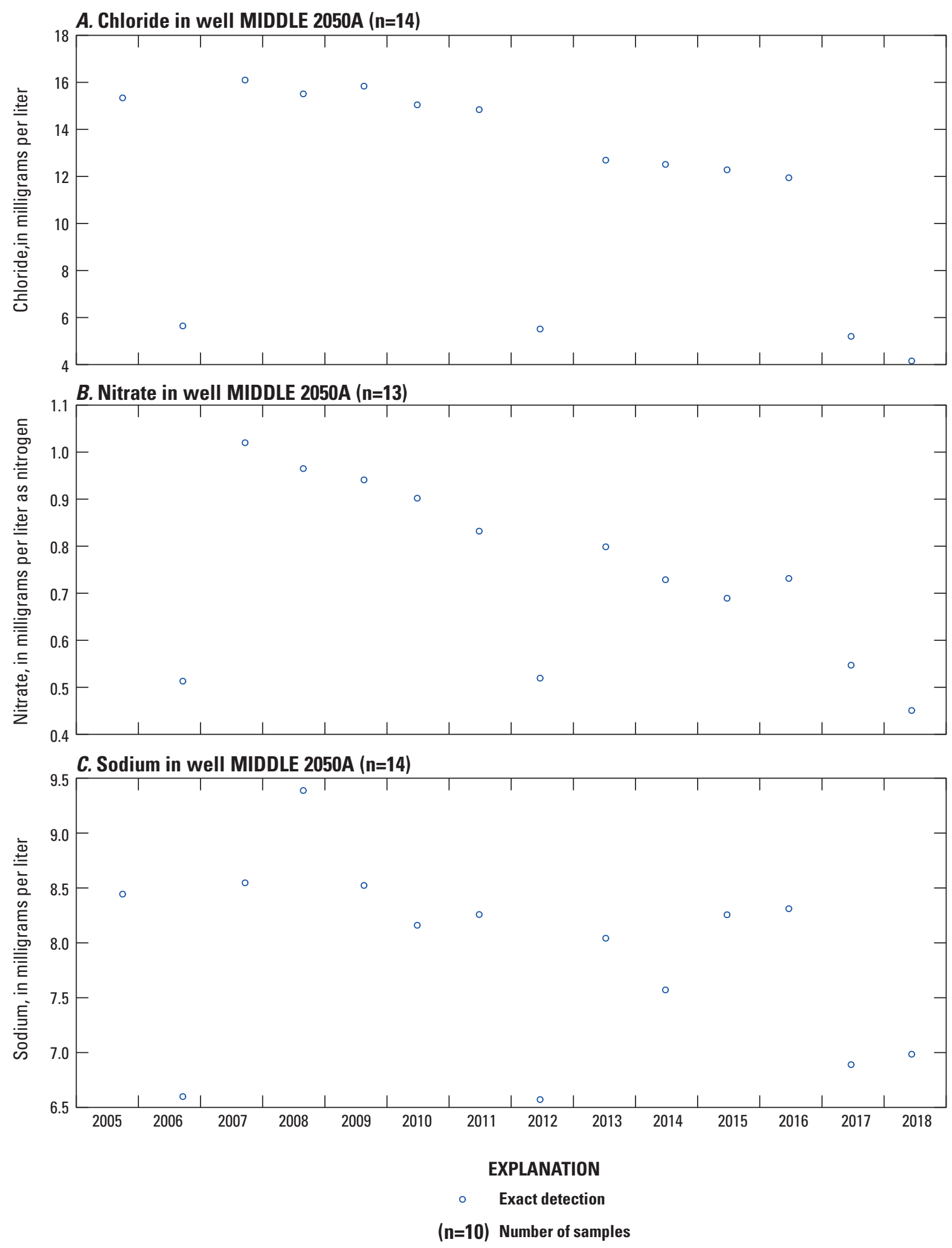

Figure 10. Survival regression model graphs showing $(A)$ chloride, $(B)$ nitrate, $(C)$ sodium, $(D)$ sulfate, and $(E)$ chromium measured in water samples collected from well MIDDLE 2050A (Site No. 433409112570515), Idaho National Laboratory, Idaho, 2005-18. 

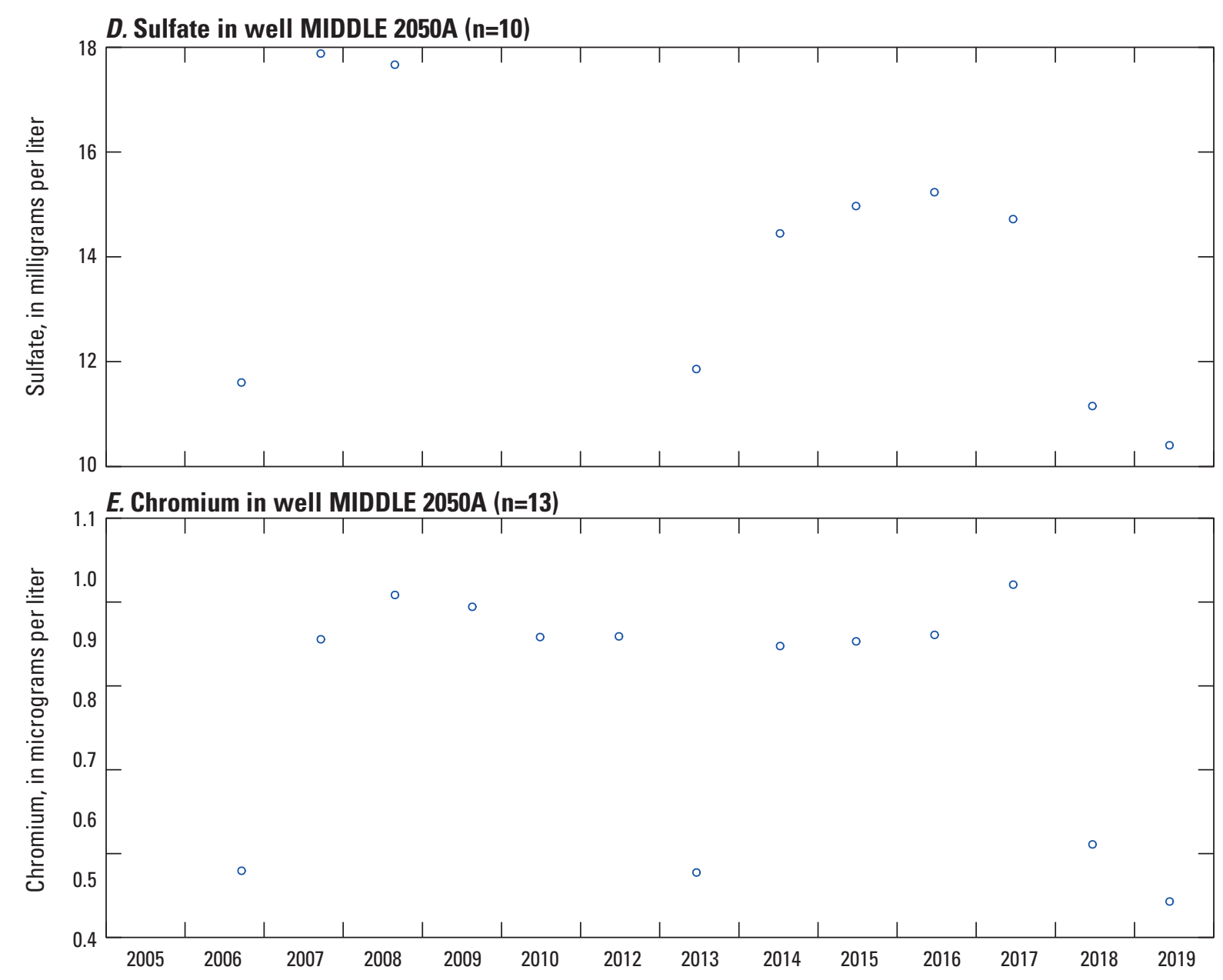

Figure 10.-Continued

Chromium concentrations in several of the MLMS wells (USGS 103, 105, 108, 131A, 132, 133, 134, 137A, MIDDLE 2050A, and MIDDLE 2051) are greater than background levels and have remained mostly consistent through time (table 6, at back of report). Chromium concentrations for well USGS 133 have increased from $6.35 \mu \mathrm{g} / \mathrm{L}$ in 2014 to $8.91 \mu \mathrm{g} / \mathrm{L}$ in 2018 (table 6, at back of report). This well is downgradient from the NRF, where some wastewater disposal has affected chromium concentrations in the aquifer, so the increasing concentrations may be from the movement of water from the NRF area. Well USGS 135 has had consistent concentrations less than background levels for the ESRP aquifer. Well MIDDLE 2050A had lower concentrations during 2006, 2012, 2017, and 2018 than during the other sample years that are attributed to surface water recharge from the BLR (figs. 8 and 10).

\section{Sodium}

Sodium has been discharged in wastewater at several facilities in the western part of the INL since 1952 and is still being discharged near the INTEC, ATR Complex, and NRF into infiltration ponds and ditches. The background sodium concentration in groundwater in the western part of the ESRP aquifer at the INL is about $8 \mathrm{mg} / \mathrm{L}$ (Bartholomay and Hall, 2016). Concentrations of sodium for selected zones in all MLMS wells ranged from $6.1 \mathrm{mg} / \mathrm{L}$ in well USGS 135 (port 9) to $12.9 \mathrm{mg} / \mathrm{L}$ in well USGS 132 (port 18) (table 6, at back of report).

Sodium concentrations in well USGS 103 (ports 1, 3, 7, and 11) also have remained consistent for the period of sample record, with all concentrations near background levels for the ESRP aquifer (table 6, at back of report). Sodium concentrations in well USGS 105 (ports 6, 10, and 14) have remained consistent for the period of sample record, with all three zones having concentrations greater than background levels. Sodium concentrations in well USGS 108 (ports 1 and 12) have remained consistent for the period of sample record with both zones having concentrations near background levels. Sodium concentrations in well USGS 131A (ports 3, 6, 10, and 15) have increased slightly in the past four years and ranged from $7.4 \mathrm{mg} / \mathrm{L}$ in port 15 to $9.9 \mathrm{mg} / \mathrm{L}$ in port 10 (table 6, at back of report). Sodium concentrations in well USGS 132 (port 18) have remained consistent and were slightly greater than background levels. Sodium concentrations in well(s) USGS 
133, 134, and 135 have shown consistent concentrations that were at or less than background levels in the ESRP aquifer. Well USGS 137A (ports 1, 3, 5, and 7) has sodium concentrations that ranged from 9.6 to $12.1 \mathrm{mg} / \mathrm{L}$, with sodium slightly elevated in the upper part of the aquifer at this location and concentrations decreasing deeper in the aquifer (table 6, at back of report; Bartholomay and others, 2015, fig. 14). Well Middle 2050A (port 15) sodium concentrations were lowest during the years 2006, 2012, 2017, and 2018, which were attributed to dilution from BLR recharge (Bartholomay and others, 2020, figs. 8 and 10). Well MIDDLE 2051 (ports 1, 3, 6 , and 9) sodium concentrations generally were near the background level and have remained consistent throughout their period of record.

\section{Sulfate}

Sulfate has been discharged in wastewater at several facilities in the western part of the INL since 1952 and is still being discharged near the INTEC, ATR Complex, and NRF into infiltration ponds and ditches. The background sulfate concentration in groundwater in the western part of the ESRP aquifer at the INL is about $21 \mathrm{mg} / \mathrm{L}$ (Bartholomay and Hall, 2016). For comparison to health standards, the secondary MCL for drinking water is $250 \mathrm{mg} / \mathrm{L}$ (U.S. Environmental Protection Agency, 2019a). Concentrations of sulfate for selected zones in all MLMS wells ranged from $18.4 \mathrm{mg} / \mathrm{L}$ in well MIDDLE 2050A (port 15) to $28.3 \mathrm{mg} / \mathrm{L}$ in well USGS 131A (port 10) (table 6, at back of report).

During 2014-18, sulfate concentrations in well USGS 103 (ports 1, 3, 7, and 11) have remained consistent with all concentrations near background levels for the ESRP aquifer (table 6, at back of report). Sulfate concentrations in well USGS 105 (ports 6, 11, and 14) have remained consistent for the period of sample record or slightly decreased, with all three zones having concentrations greater than background levels (table 6, at back of report). Sulfate concentrations in well USGS 108 (ports 1 and 12) have remained consistent or slightly decreased for the period of sample record, with both zones having concentrations greater than background levels (table 6, at back of report).

Sulfate concentrations in the upper two zones (ports 15 and 10) from USGS 131A have remained relatively consistent in the past 5 years; the upper zone (port 15) has concentrations slightly greater than background levels and the deeper zone (port 10) has concentrations greater than background levels (table 6, at back of report). Sulfate concentrations for MLMS well USGS 132 (port 18) have remained consistent and are greater than background levels (table 6, at back of report). Sulfate concentrations for well(s) USGS 133, 134, and 135 have shown consistent concentrations that were below background levels in the aquifer (table 6, at back of report). Sulfate concentrations in well USGS 137A (ports 5 and 7) were greater than background levels. Sulfate concentrations in MLMS well MIDDLE 2050A (port 15) ranged from 18.4 to $23.2 \mathrm{mg} / \mathrm{L}$ (table 6, at back of report); concentrations decreased substantially during 2006, 2012, 2017, 2018, probably because of flow in the BLR (figs. 8 and 10). Well MIDDLE 2051 (ports 1, 3, 6, and 9) had sulfate concentrations ranging from 22.6 to $26.6 \mathrm{mg} / \mathrm{L}$ (table 6 , at back of report); however, concentrations were slightly higher in ports 6 and 9 than in ports 1 and 3, which are deeper in the ESRP aquifer.

\section{Nitrate}

Nitrate has been discharged in wastewater at the INTEC into the disposal well and infiltration ponds and was leaked at the INTEC tank farm during a transfer from one tank to another (Cahn and others, 2006). The background nitrate concentration in the water in the western part of the ESRP aquifer at the INL is about $0.66 \mathrm{mg} / \mathrm{L}$ (Bartholomay and Hall, 2016). For comparison to health standards, the MCL for drinking water is $10 \mathrm{mg} / \mathrm{L}$ (U.S. Environmental Protection Agency, $2019 b$ ). Nitrite plus nitrate (hereinafter referred to as nitrate because nitrite is negligible) concentrations from 2014 to 2018 are given in table 7 , at back of report.

During 2014-18, nitrate concentrations for well USGS 103 (ports 1, 3, 7, and 11) have remained consistent, ranging from 0.643 to $0.820 \mathrm{mg} / \mathrm{L}$. Nitrate concentrations in well USGS 105 (ports $6,10,14$ ) have remained consistent, with concentrations slightly greater than background levels, ranging from 0.689 to $0.956 \mathrm{mg} / \mathrm{L}$. Nitrate concentrations for well USGS 108 (ports 1 and 12) have remained consistently greater than background levels, ranging from 0.881 to $1.03 \mathrm{mg} / \mathrm{L}$. Nitrate concentrations for well USGS 131A (ports 3, 6, 10, and 15) have remained consistently greater than background levels, ranging from 0.859 to $1.31 \mathrm{mg} / \mathrm{L}$. Nitrate concentrations for well USGS 132 (port 18) have remained consistent at levels slightly greater than background concentrations, ranging from 0.717 to $0.886 \mathrm{mg} / \mathrm{L}$. Nitrate concentrations in MLMS well USGS 133 (port 12) have remained consistent at levels slightly greater than background levels, ranging from 0.779 to $0.827 \mathrm{mg} / \mathrm{L}$. Nitrate concentrations in well USGS 134 (port 19) have remained consistent near background levels, ranging from 0.612 to $0.706 \mathrm{mg} / \mathrm{L}$. Nitrate concentrations in well USGS 135 (port 9) have remained consistently less than background concentrations, ranging from 0.564 to $0.619 \mathrm{mg} / \mathrm{L}$. Nitrate concentrations in well USGS 137A (ports 1, 3, 5, and 7) have remained consistently near background levels, ranging from 0.602 to $0.802 \mathrm{mg} / \mathrm{L}$. Nitrate concentrations in well MIDDLE 2050A (port 15) showed a statistically significant decreasing trend (fig. 10) and were slightly above background concentrations, except during years when there was flow in the BLR (2006, 2012, 2017, and 2018) (Bartholomay and others, 2020; figs. 8 and 10), when concentrations were well below background levels. Nitrate concentrations in well MIDDLE 2051 (ports 1, 3, 6, and 9) remained consistent at levels slightly greater than background levels, ranging from 0.817 to $0.941 \mathrm{mg} / \mathrm{L}$. 


\section{Gross Alpha- and Beta-Particle Radioactivity}

Gross alpha- and beta-particle radioactivity is a measure of the total radioactivity emitted as alpha and beta particles during the radioactive decay process. The radioactivity usually is reported as if it occurred as 1 radionuclide. Gross alpha and beta measurements are used to screen for radioactivity in the aquifer as a possible indicator of groundwater contamination. Water samples collected during 2014-18 were analyzed for gross alpha- and gross beta-particle radioactivity by the RESL. In 2008, the RESL increased the sensitivity of the gross alphaand gross beta-particle radioactivity and changed the radionuclide reported for gross alpha-particle radioactivity from plutonium-239 to thorium-230, and for gross beta-particle radioactivity from cesium- 137 to strontium-90/yttrium- 90 . The minimum detectable activity decreased from about 1.6 to 1.5 picocuries per liter $(\mathrm{pCi} / \mathrm{L})$ for gross alpha-particle radioactivity and from about 6.4 to $3.4 \mathrm{pCi} / \mathrm{L}$ for gross beta-particle radioactivity, allowing for increased detectable concentrations (Bartholomay and Twining, 2010).

During 2014-18, water from 22 zones from 11 MLMS wells was sampled and analyzed for gross alpha-particle radioactivity. Two MLMS wells had one sample each that equaled or exceeded the reporting level, with well USGS 105 (port 14) having a concentration of $9 \pm 3 \mathrm{pCi} / \mathrm{L}$ and MLMS well USGS 108 (port 12) having a concentration of $15 \pm 4 \mathrm{pCi} / \mathrm{L}$ (table 8 , at back of report). Alpha-particle radioactivity concentrations in all other water samples were less than the reporting level. The lack of consistent concentrations of gross alpha-activity may indicate that the detections are false positives.

During 2014-18, concentrations of gross-beta particle radioactivity in water from several of the wells equaled or exceeded the reporting level in at least one of the sampling periods, and concentrations ranged from $2.1 \pm 0.7 \mathrm{pCi} / \mathrm{L}$ to $4.8 \pm 0.9 \mathrm{pCi} / \mathrm{L}$ in well USGS 108 (port 1) and well USGS $131 \mathrm{~A}$ (port 15), respectively (table 8 , at back of report). Concentrations in all samples from wells USGS 134, 135 and MIDDLE 2050A were less than the reporting level. The upper two zones in well USGS 131A (port 10 and 15), 7 of the 10 samples collected exceeded the reporting level (table 8, at back of report). Tritium, a beta emitter, is present in these wells and probably explains why gross-beta particle radioactivity also is present.

\section{Tritium}

Tritium was discharged in wastewater to a disposal well at the INTEC and into infiltration ponds at the INTEC and the ATR Complex from 1952 until the early 1990s (Bartholomay and others, 2020). The background tritium concentration in the water in the western part of the ESRP aquifer at the INL is about $34 \mathrm{pCi} / \mathrm{L}$ (Bartholomay and Hall, 2016). For comparison to the health standard, the MCL for drinking water is 20,000 pCi/L (U.S. Environmental Protection Agency, 2019a), and tritium has a half-life of 12.3 years (Walker and others, 1989, p. 20). Concentrations for tritium for all samples collected during 2014-18 are given in table 8, at back of report.

Wells USGS 108, 133, 134, 135, 137A, and MIDDLE 2050A have tritium concentrations mostly less than the reporting levels. Most concentrations of tritium in wells USGS 105 and 132 are greater than the reporting levels, and concentrations were mostly consistent during 2014-18 (table 8, at back of report; fig. 11). Wells USGS 103, 131A, MIDDLE 2051 have concentrations mostly greater than the reporting levels and show statistically significant decreasing concentrations through time in USGS 103 (zone 1), USGS 131A (zone 12), and Middle 2051 (zone 9) (fig. 11). Decreases in tritium concentrations are attributed to discontinued disposal, radioactive decay, and dilution and dispersion in the aquifer.

\section{Cesium-137}

Cesium-137 was discharged to the radioactive-waste infiltration ponds at the ATR Complex from 1952 until the ponds closed in 1993. Additionally, cesium-137 was discharged at the INTEC facility into its disposal well and infiltration ponds and an estimated 19,100 curies was reported leaked at the INTEC Tank farm in 1972 (Cahn and others, 2006). The half-life of cesium-137 is 30.17 years (Walker and others, 1989, p. 34).

During 2014-15, groundwater was sampled and analyzed for cesium-137 using gamma spectometry for all MLMS wells (table 8, at back of report). All MLMS samples collected during 2014-15 had concentrations at or less than the reporting level. Because cesium-137 mostly was not detected in the wells, sampling was discontinued starting in 2016. 
A. Tritium in well USGS 103 zone 1 ( $n=13, \Delta=-8.7$ percent change per year)

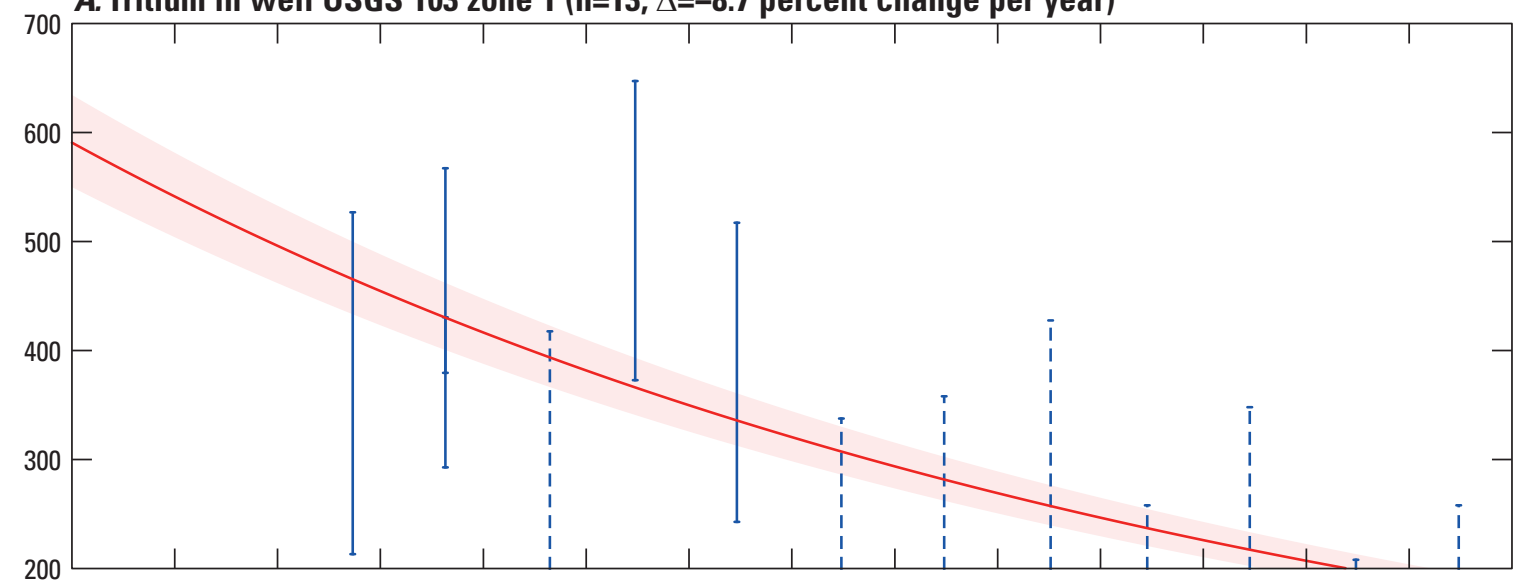

B. Tritium in well USGS 103 zone $3(n=13)$

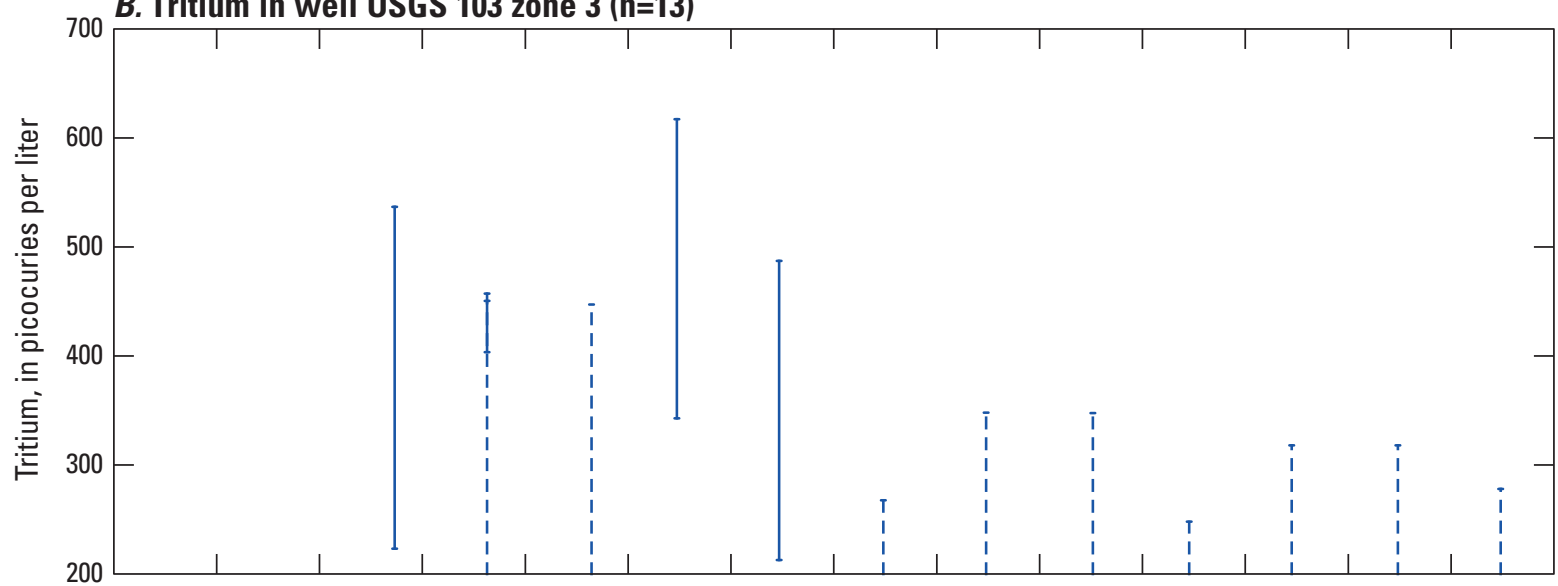

C. Tritium in well USGS 103 zone 6 ( $n=14)$

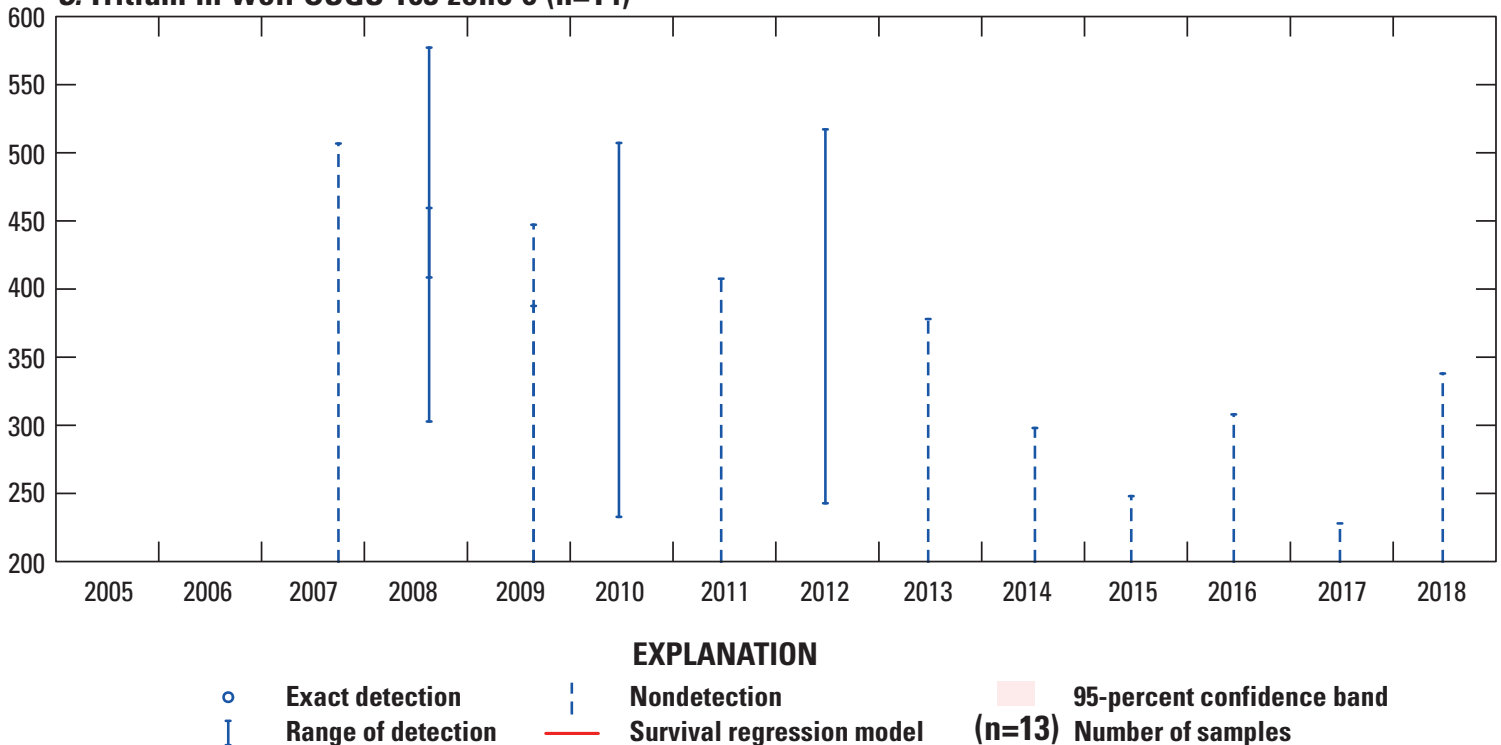

Figure 11. Survival regression model graphs showing tritium measured in water samples collected from wells $(A)$ U.S. Geological Survey (USGS) 103 (Site No. 432714112560702), (B) USGS 103 (Site No. 432714112560704), (C) USGS 103 (Site No. 432714112560708), (D) USGS 103 (Site No. 432714112560712), (E) USGS 105 (Site No. 432703113001807), (F) USGS 105 (Site No. 432703113001811), (G) USGS 105 (Site No. 432703113001815), ( H) USGS 131A (Site No. 433036112581810), (/) USGS 131A (Site No. 433036112581815), (J) USGS 132 (Site No. 432906113025018), (K) MIDDLE 2051 (Site No. 433217113004903), and (L) MIDDLE 2051 (Site No. 433217113004909), Idaho National Laboratory Idaho, 2005-18. Delta symbol ( ) represents the percent change shown by the trend line based on the survival regression model. 


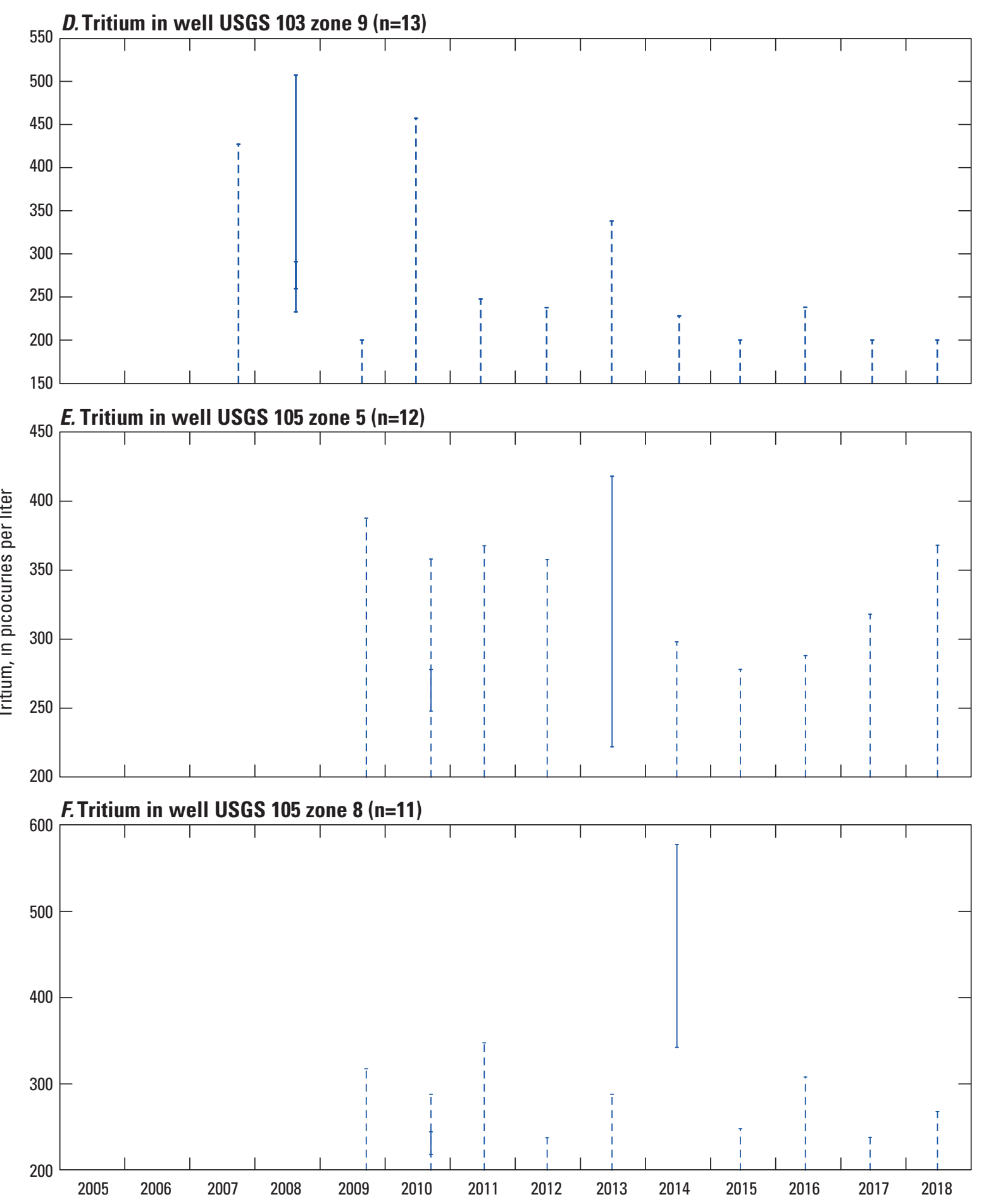

Figure 11.-Continued 


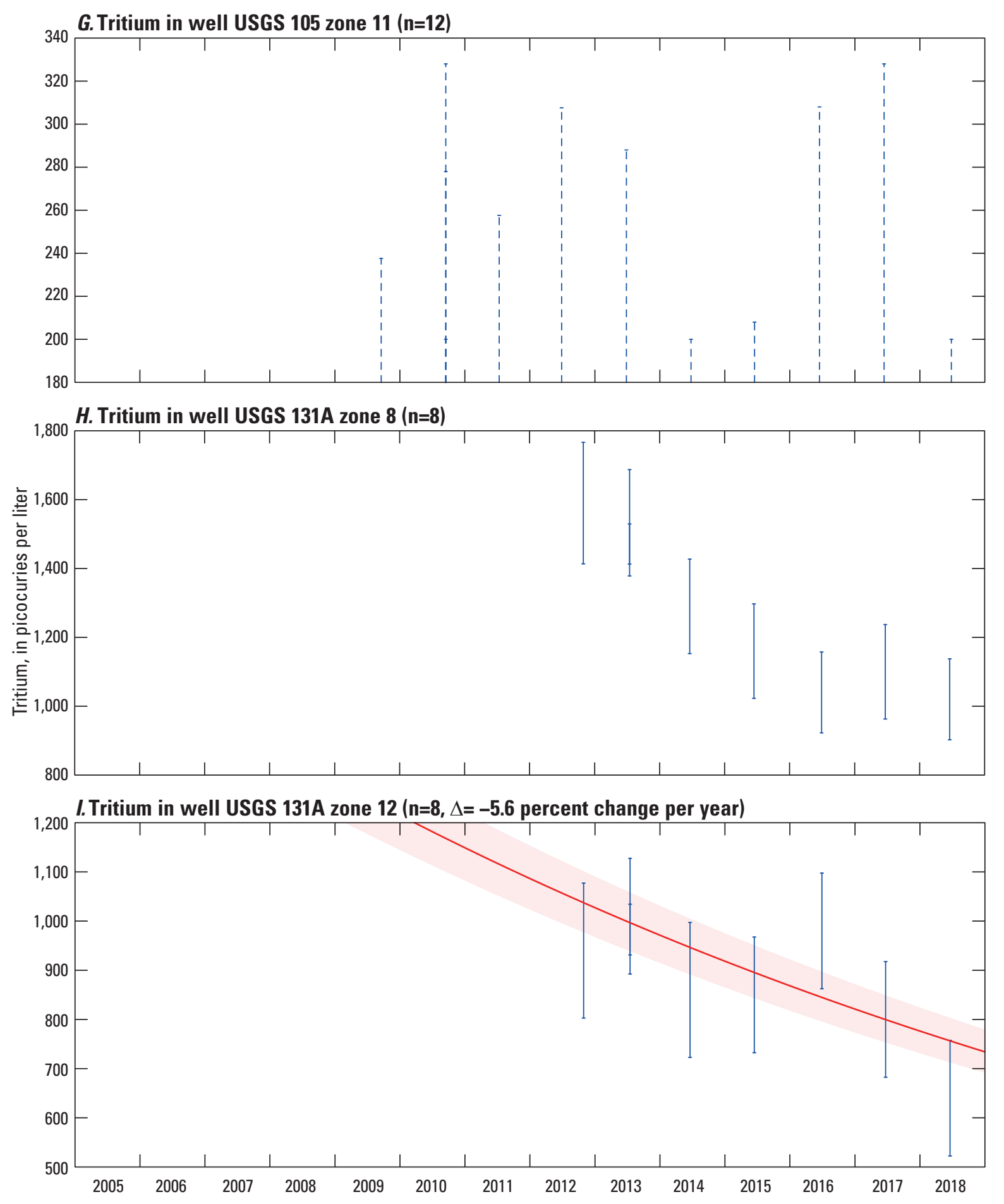

Figure 11.-Continued 

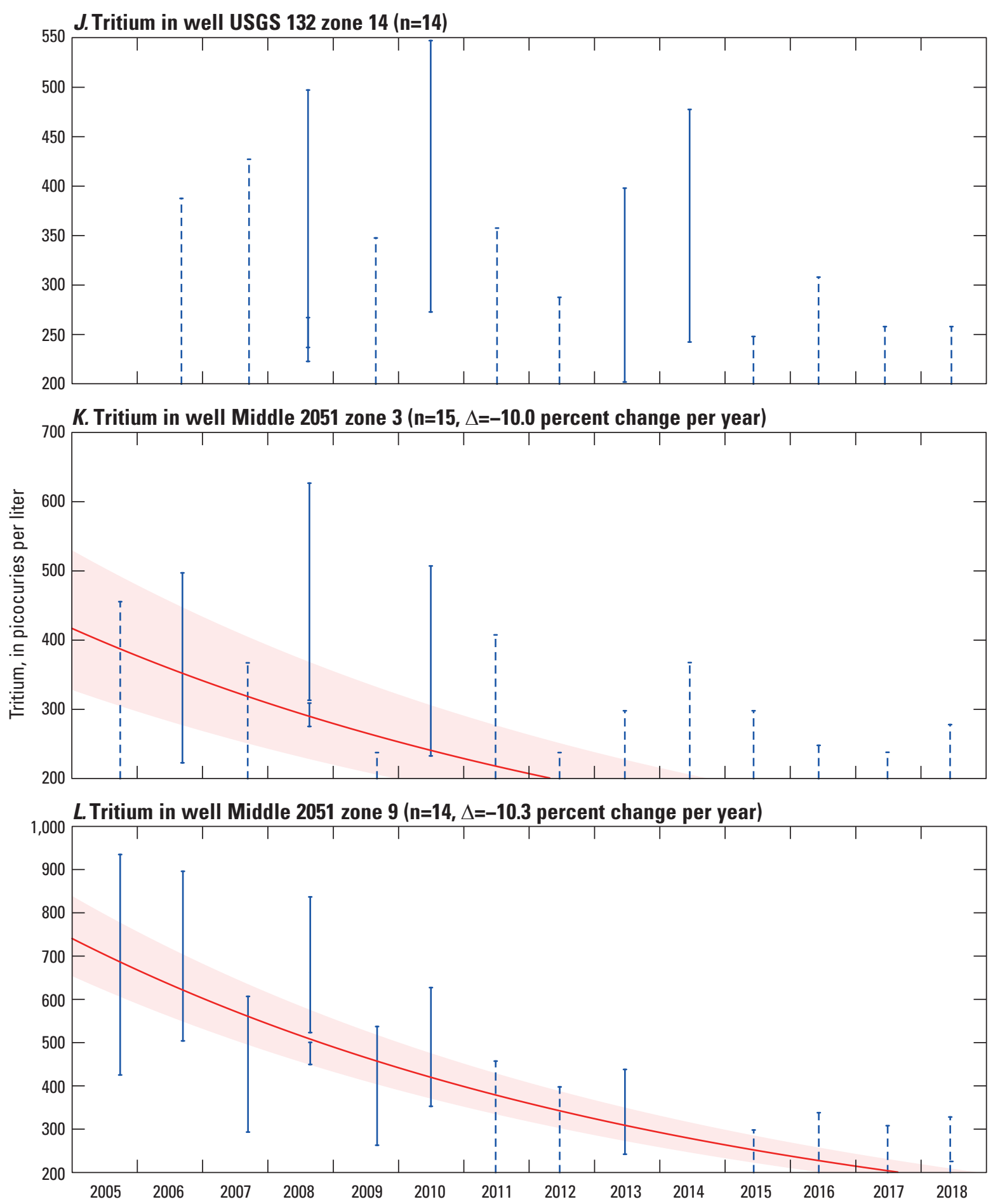

Figure 11.-Continued 


\section{Purgeable Organic Compounds}

In 2015, the INL contractor Fluor detected purgeable organic compounds (POCs) in well MIDDLE 2051, mainly tetrachloroethene (PCE); previous sampling did not detect any POCs (Forbes and Lawrence, 2018). Because of the questionable detections, the USGS was asked to sample the well with Fluor and the Idaho Department of Environmental Quality INL oversight program in 2016. Initial sampling of MLMS well MIDDLE 2051 on June 8, 2016, showed a large concentration $(744 \mu \mathrm{g} / \mathrm{L})$ of PCE and a small concentration of trichloroethene (table 10, at back of report). The concentration of PCE was greater than anticipated levels and resulted in an extensive research study to try to find the source of the PCE (Forbes and Lawrence, 2018). To verify data previously reported, an entire suite of chemical constituents were collected and analyzed for well MIDDLE 2051 (port 1) on June 30, 2016 (table 9, at back of report). Results indicated that the 2016 chemical concentrations reported for well MIDDLE 2051 (port 1) were similar to concentration levels previously reported (Bartholomay and Twining, 2010), so it was concluded that the aquifer was not undergoing any extreme chemical change indicated by the POC results. The resample in well MIDDLE 2051 (port 1) for POCs indicated that PCE was still present but at a much lower concentration of $0.774 \mu \mathrm{g} / \mathrm{L}$ (tables 9 and 10, at back of report). Upon further investigation, we determined that the initial sample collected on June 8, 2016, probably was contaminated with tubing fluid (Forbes and Lawrence, 2018). Tubing fluid is water that was added during the installation of the MLMS. Fluor MLMS installation records indicated that the tubing fluid in wells MIDDLE 2050A and MIDDLE 2051 was well water from Firestation \#2 and that well water was sampled by Fluor and PCE was not detected (Forbes, and Lawrence, 2018); however, all USGS MLMS wells are filled with deionized bottled water.

To determine if the tubing contained elevated concentrations of PCE the tubing fluid was sampled on July 19, 2016 at well MIDDLE 2051. The tubing fluid sampled at well MIDDLE 2051 had a PCE concentration of $662 \mu \mathrm{g} / \mathrm{L}$ (table 10, at back of report). Because of the large concentration found in the tubing fluid in well MIDDLE 2051, we decided to sample the tubing fluid in all the MLMS wells. Results from three other MLMS wells (USGS 132, USGS 137A, and MIDDLE 2050A) sampled by the USGS are given in table 10, at back of report; results from Fluor sampling are given in Forbes and Lawrence (2018). Results indicated that three of the MLMS wells USGS 137A, MIDDLE 2050A, and MIDDLE 2051 had PCE above acceptable levels and cleanup, as described by Forbes and Lawrence (2018), was done to decrease PCE contamination in the tubing fluid to acceptable levels.

In addition to POC sampling at well MIDDLE 2051, POCs in wells USGS 132 and USGS 137A were sampled because these wells are downgradient from the RWMC and known concentrations of several POCs originate from waste disposal at the RWMC (Bartholomay and others, 2017). Results indicate that the aquifer has detectable concentrations of tetrachloromethane (carbon tetrachloride) for all MLMS zones for well USGS 132 (ports 1, 6, 10, 14, 18, and 22) and in two zones for well USGS 137A (ports 1 and 7) (table 10, at back of report). Tetrachloromethane has been found in several of the wells around the RWMC, so these detections and concentration levels seem reasonable for the well locations. Because of the concentrations found in well USGS 132, POC analyses were added to the sample schedule for the zone routinely sampled from well USGS 132 starting in 2017. PCE was not detected in well USGS 137A (ports 1, 3, 5, and 7) and only a trace amount was detected in one zone in well USGS 132 (port 14) (table 10, at back of report).

\section{Summary}

Radiochemical and chemical wastewater discharged to infiltration ponds and disposal wells since the early 1950s at the Idaho National Laboratory (INL), southeastern Idaho, has affected the water quality of the eastern Snake River Plain aquifer. In 2005, the U.S. Geological Survey (USGS), in cooperation with the U.S. Department of Energy, added a multilevel well-monitoring network to their ongoing monitoring program to begin describing the vertical movement and distribution of the chemical constituents in the eastern Snake River Plain aquifer.

Vertical head and temperature change were quantified for each of the 11 multilevel monitoring systems. Fractured basalt zones generally had relatively small vertical head differences and showed a higher occurrence within volcanic rift zones. Poor connectivity between fractures and higher vertical gradients generally was attributed to sediment layers and (or) layers of dense basalt. Hydraulic head ranged from 4,415.5 to 4,462.6 feet above the National Geodetic Vertical Datum of 1929 in wells U.S. Geological Survey (USGS) 135 and USGS 133, respectively; groundwater temperature ranged from 10.4 to 16.8 degrees Celsius in wells MIDDLE 2051 and MIDDLE 2050A, respectively.

Normalized mean head values were analyzed for all 11 multilevel monitoring wells for the period of record (2007-18). The mean head values suggest a moderately positive correlation among all multilevel monitoring system (MLMS) wells and generally reflect regional fluctuations in water levels in response to seasonal climatic changes. MLMS wells within volcanic rift zones and near the southern boundary (USGS 103, USGS 105, USGS 108, USGS 132, USGS 135 , USGS 137A) indicated a temporal correlation that is strongly positive. MLMS wells in the Big Lost Trough indicate some variations in temporal correlations that may result from proximity to the mountain front to the northwest and episodic flow in the Big Lost River drainage system.

During 2014-18, water samples were collected from one to four discrete sampling zones in the upper 250-750 feet of the aquifer from 11 wells and were analyzed for selected radionuclides, inorganic constituents, organic constituents, and 
nutrients. Some additional samples were collected for volatile organic compounds near the Radioactive Waste Management Complex (RWMC).

Nine quality-control replicate samples were collected during $2014-18$ as a measure of quality assurance; three field blanks and two equipment blanks also were collected using deionized water from the USGS Idaho Falls Field Office. Concentrations of major ions and chromium in equipment blank samples were near or less than the reporting levels, suggesting no background contamination from field equipment or source water. About 88 percent of the replicate pairs for radionuclide results were statistically comparable and 100 percent of the replicate pairs for inorganic and organic compounds were statistically comparable. The sample results for most of the quality assurance samples indicate that sample collection and laboratory procedures used were appropriate for the data collected.

Concentrations of chloride, chromium, nitrate, sodium, and sulfate in most of the wells showed mostly consistent concentrations with time. Concentrations in well Middle 2050A were markedly lower during 2017 and 2018 than during other sample years and the decrease in concentrations is attributed to flow in the Big Lost River during those years. Chromium showed increasing concentrations in USGS 133. Concentrations of most of the chemical constituents were greater than background concentration levels in wells USGS 103, 105, 108, 131A, 132, 137A, and MIDDLE 2051, and were at or less than background levels in wells USGS 133, 134 , and 135.

Tritium concentrations in wells USGS 108, 133, 134, 135, 137A, and MIDDLE 2050A, mostly were less than reporting levels. Most well USGS 105 and 132 concentrations were greater than the reporting levels and concentrations were mostly consistent. Wells USGS 103, USGS 131A, and MIDDLE 2051 had concentrations mostly greater than the reporting level and showed decreasing concentrations. The decreasing concentrations are attributed to discontinued disposal, radioactive decay, and dilution and dispersion in the aquifer.

The volatile organic compound tetrachloromethane was found in all zones sampled in well USGS 132 near RWMC and was found in two zones in well USGS 137A. Concentrations are attributed to waste disposal at the RWMC. Questionable detections of tetrachloroethene were found in well MIDDLE 2051; the source probably was tubing fluid in the well. Tetrachloroethene was found in the tubing fluid at elevated concentrations in three wells (USGS 137A, MIDDLE 2050A, and MIDDLE 2051), and this compound is being removed from the tubing fluid.

\section{References Cited}

Ackerman, D.J., 1991, Transmissivity of the Snake River Plain aquifer at the Idaho National Engineering Laboratory, Idaho: U.S. Geological Survey Water-Resources Investigations Report 91-4058 (DOE/ID-22097), 35 p.

Ackerman, D.J., Rattray, G.W., Rousseau, J.P., and Fisher, J.C., 2010, Steady-state and transient models of groundwater flow and advective transport, Eastern Snake River Plain aquifer, Idaho National Laboratory and vicinity, Idaho: U.S. Geological Survey Scientific Investigations Report 2010-5123 (DOE/ID-22209), 220 p.

Anderson, S.R., Ackerman, D.J., Liszewski, M.J., and Freiburger, R.M., 1996, Stratigraphic data for wells at and near the Idaho National Engineering Laboratory, Idaho: U.S. Geological Survey Open-File Report 96-248 (DOE/ID-22127), 27 p. plus 1 diskette. [Also available at http://pubs.er.usgs.gov/publication/ofr96248.]

Anderson, S.R., Kuntz, M.A., and Davis, L.C., 1999, Geologic controls of hydraulic conductivity in the Snake River Plain aquifer at and near the Idaho National Engineering and Environmental Laboratory, Idaho: U.S. Geological Survey Water-Resources Investigations Report 99-4033 (DOE/ ID-22155), 38 p. [Also available at http://pubs.er.usgs.gov/ publication/wri994033.]

Anderson, S.R., and Liszewski, M.J., 1997, Stratigraphy of the unsaturated zone and the Snake River Plain aquifer at and near the Idaho National Engineering Laboratory, Idaho: U.S. Geological Survey Water-Resources Investigations Report 97-4183 (DOE/ID-22142), 65 p., https://doi.org/ 10.3133/wri974183.

Bartholomay, R.C., 2009, Iodine-129 in the Snake River Plain aquifer at and near the Idaho National Laboratory, Idaho, 2003 and 2007: U.S. Geological Survey Scientific Investigations Report 2009-5088 (DOE/ID-22208), 28 p. [Also available at https://pubs.usgs.gov/sir/2009/5088/.]

Bartholomay, R.C., 2013, Iodine-129 in the eastern Snake River Plain aquifer at and near the Idaho National Laboratory, Idaho, 2010-12: U.S. Geological Survey Scientific Investigations Report 2013-5195 (DOE/ ID-22225), 22 p., https://pubs.usgs.gov/sir/2013/5195/.

Bartholomay, R.C., and Hall, L.F., 2016, Evaluation of background concentrations of selected chemical and radiochemical constituents in water from the eastern Snake River Plain aquifer at and near the Idaho National Laboratory, Idaho: U.S. Geological Survey Scientific Investigations Report 2016-5056 (DOE/ID-22237), 19 p., https://doi.org/10.3133/ sir20165056. 
Bartholomay, R.C., Hopkins, C.B., and Maimer, N.V., 2015, Chemical constituents in groundwater from multiple zones in the eastern Snake River Plain aquifer, Idaho National Laboratory, Idaho, 2009-13: U.S. Geological Survey Scientific Investigations Report 2015-5002 (DOE/ ID-22232), 110 p. [Also available at https://pubs.usgs.gov/ $\operatorname{sir} / 2015 / 5002 /$.

Bartholomay, R.C., Maimer, N.V., Rattray, G.W., and Fisher, J.C., 2017, An update of hydrologic conditions and distribution of selected constituents in water, eastern Snake River Plain aquifer and perched groundwater zones, Idaho National Laboratory Idaho, emphasis 2012-15: U.S. Geological Survey Scientific Investigations Report 2017-5021 (DOE/ID-22242), 87 p., https://doi.org/10.3133/ sir20175021.

Bartholomay, R.C., Maimer, N.V., Rattray, G.W., and Fisher, J.C., 2020, An update of hydrologic conditions and distribution of selected constituents in water, eastern Snake River Plain aquifer and perched groundwater zones, Idaho National Laboratory Idaho, emphasis 2016-18: U.S. Geological Survey Scientific Investigations Report 2019-5149 (DOE/ID-22251), 82 p., https://doi.org/10.3133/ sir20195149.

Bartholomay, R.C., Maimer, N.V., and Wehnke, A.J., 2014, Field methods and quality-assurance plan for water-quality activities and water level measurements, U.S. Geological Survey, Idaho National Laboratory, Idaho: U.S. Geological Survey Open-File Report 2014-1146 (DOE/ID-22230), 66 p., https://pubs.usgs.gov/of/2014/1146/

Bartholomay, R.C., Tucker, B.J., Ackerman, D.J., and Liszewski, M.J., 1997, Hydrologic conditions and distribution of selected radiochemical and chemical constituents in water, Snake River Plain aquifer, Idaho National Engineering Laboratory, Idaho, 1992 through 1995: U.S. Geological Survey Water-Resources Investigations Report 97-4086 (DOE/ID-22137), 57 p.

Bartholomay, R.C., and Twining, B.V., 2010, Chemical constituents in groundwater from multiple zones in the eastern Snake River Plain Aquifer at the Idaho National Laboratory, Idaho, 2005-08: U.S. Geological Survey Scientific Investigations Report 2010-5116, 82 p., https://doi.org/ $10.3133 / \operatorname{sir} 20105116$.

Bartholomay, R.C., Twining, B.V., and Rose, P.E., 2013, Ambient changes in tracer concentrations from a multilevel monitoring system in basalt: Ground Water Monitoring and Remediation, v. 34, no. 1, p. 79-88.

Blair, J.J., 2002, Sedimentology and stratigraphy of sediments of the Big Lost trough subsurface from selected coreholes at the Idaho National Engineering and Environmental Laboratory: Pocatello, Idaho, Idaho State University, Master's thesis, $148 \mathrm{p}$.
Bodnar, L.Z., and Percival, D.R., eds., 1982, Analytical Chemistry Branch procedures manual-Radiological and Environmental Sciences Laboratory: U.S. Department of Energy Report IDO-12096, [variously paged].

Busenberg, E., Plummer, L.N., and Bartholomay, R.C., 2001, Estimated age and source of the young fraction of groundwater at the Idaho National Engineering and Environmental Laboratory: U.S. Geological Survey Water-Resources Investigations Report 01-4265 (DOE/ID-22177), 144 p.

Cahn, L.S., Abbott, M.L., Keck, J.F., Martian, P., Schafer, A.L., and Swenson, M.C., 2006, Operable Unit 3-14 Tank Farm soil and groundwater remedial investigation/baseline risk assessment: U.S. Department of Energy, Idaho Operations Office, DOE/NE-ID-11227, [variously paged].

Cecil, L.D., Welhan, J.A., Green, J.R., Grape, S.K., and Sudicky, E.R., 2000, Use of chlorine-36 to determine regional-scale aquifer dispersivity, eastern Snake River Plain aquifer, Idaho/USA: Nuclear Instruments and Methods in Physics Research Section B, v. 172, p. 679-687.

Currie, L.A., 1984, Lower limit of detection-Definition and elaboration of a proposed position for radiological effluent and environmental measurements: U.S. Nuclear Regulatory Commission, NUREG/CR-4007, 139 p.

Davis, L.C., Bartholomay, R.C., Fisher, J.C., and Maimer, N.V., 2015, Water-quality characteristics and trends for selected wells possibly influenced by wastewater disposal at the Idaho National Laboratory, Idaho, 1981-2012: U.S. Geological Survey Scientific Investigations Report 2015-5003 (DOE/ID-22233), 110 p., https://doi.org/ $10.3133 /$ sir20155003.

Davis, L.C., Bartholomay, R.C., and Rattray, G.W., 2013, An update of hydrologic conditions and distribution of selected constituents in water, eastern Snake River Plain aquifer and perched groundwater zones, Idaho National Laboratory, Idaho, emphasis 2009-11: U.S. Geological Survey Scientific Investigations Report 2013-5214 (DOE/ ID-22226), 90 p., https://doi.org/10.3133/sir20135214.

Duke, C.L., Roback, R.C., Reimus, P.W., Bowman, R.S., McLing, T.L., Baker, K.E., and Hull, L.C., 2007, Elucidation of flow and transport processes in a variably saturated system of interlayered sediment and fractured rock using tracer tests: Vadose Zone Journal, v. 6, no. 4, p. $855-867$.

Faires, L.M., 1993, Methods of analysis by the U.S. Geological Survey National Water Quality LaboratoryDetermination of metals in water by inductively coupled plasma-mass spectrometry: U.S. Geological Survey OpenFile Report 92-634, 28 p. 
Fisher, J.C., and Twining, B.V., 2011, Multilevel groundwater monitoring of hydraulic head and temperature in the eastern Snake River Plain aquifer, Idaho National Laboratory, Idaho, 2007-08: U.S. Geological Survey Scientific Investigations Report 2010-5253, 62 p.

Fishman, M.J., ed., 1993, v. 93-125. Methods of analysis by the U.S. Geological Survey National Water Quality Laboratory-Determination of inorganic and organic constituents in water and fluvial sediments, U.S. Geological Survey Open-File Report, 217 p.

Fishman, M.J., and Friedman, L.C., eds., 1989, Methods for determination of inorganic substances in water and fluvial sediments: U.S. Geological Survey Techniques of WaterResources Investigations, book 5, chap. A1, 545 p.

Forbes, J.R., and Lawrence, S.D., 2018, Final report on the Westbay well Middle-2051 investigation at the Idaho National Laboratory site: U.S. Department of Energy publication DOE/ID-11571, Rev. 0, 30 p. plus appendices.

Friedman, L.C., and Erdmann, D.E., 1982, Quality assurance practices for the chemical and biological analyses of water and fluvial sediments: U.S. Geological Survey Techniques of Water-Resources Investigations, book 5, chap. A1, 545 p.

Fromm, J.R., Welhan, J.A., McCurry, M., and Hackett, W.R., 1994, Idaho Chemical Processing Plant (ICCP) injection well - Operations history and hydrochemical inventory of the waste stream: Proceedings, 30th symposium, Engineering Geology and Geotechnical Engineering, p. 221-237.

Garabedian, S.P., 1986, Application of a parameter-estimation technique to modeling the regional aquifer underlying the eastern Snake River Plain, Idaho: U.S. Geological Survey Water Supply Paper 2278, 60 p.

Geslin, J.K., Link, P.K., Riesterer, J.W., Kuntz, M.A., and Fanning, C.M., 2002, Pliocene and Quaternary stratigraphic architecture and drainage systems of the Big Lost Trough, northeastern Snake River Plain, Idaho, in Link, P.K., and Mink, L.L., eds., Geology, hydrogeology, and environmental remediation-Idaho National Engineering and Environmental Laboratory, Eastern Snake River Plain, Idaho-Boulder, Colorado: Geological Society of America Special Paper 353, p. 11-26.

Goerlitz, D.F., and Brown, E., 1972, Methods for analysis of organic substances in water: U.S. Geological Survey Techniques of Water-Resources Investigations, book 5, chap. A3, 40 p.
Hughes, S.S., Smith, R.P., Hackett, W.R., and Anderson, S.R., 1999, Mafic volcanism and environmental geology of the eastern Snake River Plain, Idaho, in Hughes, S.S., and Thackray, G.D., eds., Guidebook to the geology of eastern Idaho: Pocatello, Idaho, Idaho Museum of Natural History, p. 143-168.

Hughes, S.S., Wetmore, P.H., and Casper, J.L., 2002, Evolution of Quaternary tholeiitic basalt eruptive centers on the eastern Snake River Plain, in Bonnichsen, B., White, C.M., and McCurry, M., eds., Tectonic and magmatic evolution of the Snake River Plain volcanic province: Idaho Geological Survey Bulletin, v. 30, p. 363-385.

Jones, B.E., 1987, Quality control manual of the U.S. Geological Survey's National Water Quality Laboratory: U.S. Geological Survey Open-File Report 87-457, 17 p.

Jones, P.H., 1961, Hydrology of waste disposal, National Reactor Testing Station, Idaho, an interim report: U.S. Atomic Energy Commission, Idaho Operations Office Publication IDO-22042-USGS, 152 p.

Kuntz, M.A., Covington, H.R., and Schorr, L.J., 1992, An overview of basaltic volcanism of the eastern Snake River Plain, Idaho, in Link, P.K., Kuntz, M.A., and Platt, L.B., eds., Regional geology of eastern Idaho and western Wyoming: Geological Society of America, v. 179, p. $227-267$.

Kuntz, M.A., Skipp, B., Lanphere, M.A., Scott, W.E., Pierce, K.L., Dalrymple, G.B., Champion, D.E., Embree, G.F., Page, W.R., Morgan, L.A., Smith, R.P., Hackett, W.R., and Rodger, D.W., 1994, Geologic map of the Idaho National Engineering Laboratory and adjoining areas, eastern Idaho: U.S. Geological Survey Miscellaneous Investigations Map I-2330, scale 1:100,000.

Maimer, N.V., and Bartholomay, R.C., 2019, Iodine-129 in the eastern Snake River Plain aquifer at and near the Idaho National Laboratory, Idaho, 2017-18: U.S. Geological Survey Scientific Investigations Report 2019-5133, 20 p., https://doi.org/10.3133/sir20195133.

Mann, L.J., 1986, Hydraulic properties of rock units and chemical quality of water for INEL-1-A 10,365-foot deep test hole drilled at the Idaho National Engineering Laboratory, Idaho: U.S. Geological Survey Water-Resources Investigations Report 86-4020 (DOE/ID-22070), 23 p.

Mann, L.J., and Beasley, T.M., 1994, Iodine-129 in the Snake River Plain aquifer at the Idaho National Engineering Laboratory, Idaho, 1990-1991: U.S. Geological Survey Water-Resources Investigations Report 94-4053 (DOE/ ID-22115), $27 \mathrm{p}$. 
Mann, L.J., and Cecil, L.D., 1990, Tritium in ground water at the Idaho National Engineering Laboratory, Idaho: U.S. Geological Survey Water-Resources Investigations Report 90-4090 (DOE/ID-22090), 35 p.

McCurdy, D.E., Garbarino, J.R., and Mullin, A.H., 2008, Interpreting and reporting radiological water-quality data: U.S. Geological Survey Techniques and Methods, book 5, chap. B6, 33 p. [Also available at https://pubs.usgs.gov/ $\mathrm{tm} / 05 \mathrm{~b} 06$.

McCutcheon, S.C., Martin, J.L., and Barnwell, T.O., Jr., 1993, Water quality, chap. 11 of Maidment, D.R., ed., Handbook of hydrology: New York, McGraw-Hill, p. 3-73.

Nimmo, J.R., Perkins, K.S., Rose, P.A., Rousseau, J.P., Orr, B.R., Twining, B.V., and Anderson, S.R., 2002, Kilometerscale rapid transport of naphthalene sulfonate tracer in the unsaturated zone at the Idaho National Engineering and Environmental Laboratory: Vadose Zone Journal, v. 1, no. 1, p. 89-101.

Olmsted, F.H., 1962, Chemical and physical character of ground water in the National Reactor Testing Station, Idaho: U.S. Atomic Energy Commission, Idaho Operations Office Publication IDO-22043-USGS, [variously paged].

Parker, B.L., Cherry, J.A., and Swanson, B.J., 2006, A multilevel system for high-resolution monitoring in rotasonic boreholes: Ground Water Monitoring and Remediation, v. 26 , no. 4 , p. 57-73.

Peckham, A.E., 1959, Investigations of underground waste disposal, chemical processing plant area, National Reactor Testing Station, Idaho: U.S. Atomic Energy Commission, Idaho Operations Publication IDO-22039-USGS, 35 p.

Plummer, L.N., Rupert, M.G., Busenberg, E., and Schlosser, P., 2000, Age of irrigation water in ground water from the eastern Snake River Plain aquifer, south-central Idaho: Ground Water, v. 38, no. 2, p. 264-283.

Pritt, J.W., 1989, Quality assurance of sample containers and preservatives at the U.S. Geological Survey National Water Quality Laboratory, in Pederson, G.L., and Smith, M.M., compilers, U.S. Geological Survey Second National Symposium on Water Quality-Abstracts of the technical sessions, Orlando, Florida, November 12-17, 1989: U.S. Geological Survey Open-File Report 89-409, 111 p.

Pritt, J.W., and Raese, J.W., eds., 1995, Quality assurance/quality control manual-National Water Quality Laboratory: U.S. Geological Survey Open-File Report 95-443, $35 \mathrm{p}$.

R Development Core Team, 2014, R-A language and environment for statistical computing: Vienna, Austria, R Foundation for statistical computing, ISBN 3-900051v07-0, accessed October 2014, at http://www.R-project.org.
Robertson, J.B., Schoen, R., and Barraclough, J.T., 1974, The influence of liquid waste disposal on the geochemistry of water at the National Reactor Testing Station, Idaho, 1952-1970: U.S. Geological Survey Open-File Report 73-238 (IDO-22053), 231 p.

Rose, D.L., and Schroeder, M.P., 1995, Methods of analysis by the U.S. Geological Survey National Water Quality Laboratory - Determination of volatile organic compounds in water by purge and trap capillary gas chromatography/ mass spectrometry: U.S. Geological Survey Open-File Report 94-708, 26 p.

Sill, D.S., and Sill, C.W., 1994, Simultaneous determination of the actinides in small environmental samples: Radioactivity and Radiochemistry, v. 5, no. 2, p. 8-19.

Taylor, J.K., 1987, Quality assurance of chemical measurements: Chelsea, Michigan, Lewis Publishers, 328 p.

Timme, P.J., 1995, National Water Quality Laboratory, 1995 services catalog: U.S. Geological Survey Open-File Report 95-352, $120 \mathrm{p}$.

Thatcher, L.L., Janzer, V.J., and Edwards, K.W., 1977, Methods for determination of radioactive substances in water and fluvial sediments: U.S. Geological Survey Techniques of Water-Resources Investigations, book 5, chap. A5, 95 p.

Twining, B.V., and Fisher, J.C., 2012, Multilevel groundwater monitoring of hydraulic head and temperature in the eastern Snake River Plain aquifer, Idaho National Laboratory, Idaho, 2009-10: U.S. Geological Survey Scientific Investigations Report 2012-5259 (DOE/ID-22221), 44 p. plus appendixes.

Twining, B.V., and Fisher, J.C., 2015, Multilevel groundwater monitoring of hydraulic head and temperature in the eastern Snake River Plain aquifer, Idaho National Laboratory, Idaho, 2011-13: U.S. Geological Survey Scientific Investigations Report 2015-5042 (DOE/ID-22235), 49 p., https://doi.org/10.3133/sir20155042.

Twining, B.V., and Maimer, N.V., 2019, Transmissivity and geophysical data for selected wells located at and near the Idaho National Laboratory, Idaho, 2017-18: U.S. Geological Survey Scientific Investigations Report 2019-5134, 30 p. plus appendixes, https://doi.org/10.3133/ sir20195134.

U.S. Department of Energy, 1995, Radiochemistry manual, revision 10: Idaho Falls, Idaho, U.S. Department of Energy, Radiological and Environmental Sciences Laboratory, [variously paged]. 
U.S. Department of Energy, 2004, Monitoring report/decision summary for operable unit 3-13, group 5, Snake River Plain aquifer: U.S. Department of Energy Idaho Operations Office Publication, DOE/ID-11098, revision 1, [variously paged].

U.S. Department of Energy, 2007, Waste area group 10, operable unit 10-08, remedial investigation/feasibility study annual status report for fiscal year 2006: U.S. Department of Energy Idaho Operations Office Publication, DOE/ ID-11297, revision 0, 245 p. [Also available at https:// www.osti.gov/biblio/910308-waste-area-group-operableunit-remedial-investigation-feasibility-study-annual-statusreport-fiscal-year.]

U.S. Department of Energy, 2008, Waste area group 10, operable unit 10-08, annual monitoring status report for fiscal year 2007: U.S. Department of Energy Idaho Operations Office publication, DOE/ID-11355, revision 0, 123 p.

U.S. Environmental Protection Agency, 2019b, National Primary Drinking Water Regulations-Maximum contaminant levels and maximum residual disinfectant levels: Code of Federal Regulations, title 40, part 141, subpart G.

U.S. Environmental Protection Agency, 2019a, Secondary Drinking Water Standards-Guidance for nuisance chemicals: U.S. Environmental Protection Agency web page, accessed May 14, 2019, at https://www.epa.gov/sdwa/ secondary-drinking-water-standards-guidance-nuisancechemicals.

U.S. Geological Survey, 1985, National water summary 1984-Hydrologic events, selected water-quality trends, and ground-water resources: U.S Geological Survey Water Supply Paper 2275, 467 p.

U.S. Geological Survey, 2020, National Water Information System: U.S. Geological Survey-Web interface: U.S. Geological Survey web page, accessed June 20, 2020, at https://doi.org/10.5066/F7P55KJN.
U.S. Geological Survey, [variously dated], National field manual for the collection of water-quality data: U.S. Geological Survey Techniques of Water-Resources Investigations, book 9, chaps. A1-A9. [Also available at https://pubs.water.usgs.gov/twri9A.]

Volk, W., 1969, Applied statistics for engineers 2nd ed.: New York, McGraw-Hill Book Company, 415 p.

Walker, F.W., Parrington, J.R., and Feiner, F., 1989, Nuclides and isotopes - Chart of the nuclides (14th ed.): General Electric Company, Nuclear Energy Operations, 57 p.

Welhan, J.A., Farabaugh, R.L., Merrick, M.J., and Anderson, S.R., 2007, Geostatistical modeling of sediment abundance in a heterogeneous basalt aquifer at the Idaho National Laboratory, Idaho: U.S. Geological Survey Scientific Investigations Report 2006-5316 (DOE/ID-22201), 32 p. [Also available at http://pubs.er.usgs.gov/publication/ sir20065316.]

Wershaw, R.L., Fishman, M.J., Grabbe, R.R., and Lowe, L.E., eds., 1987, Methods for determination of organic substances in water and fluvial sediments: U.S. Geological Survey Techniques of Water-Resources Investigations, book 5,chap. A3, $80 \mathrm{p}$.

Whitehead, R.L., 1992, Geohydrologic framework of the Snake River Plain regional aquifer system, Idaho and eastern Oregon: U. S. Geological Survey Professional Paper 1408-B, 32 p. [Also available at https://doi.org/10.3133/ pp1408B.]

Williams, L.M., 1996, Evaluation of quality assurance/quality control data collected by the U.S. Geological Survey for water-quality activities at the Idaho National Engineering Laboratory, Idaho, 1989 through 1993: U.S. Geological Survey Water-Resources Investigations Report 96-4148 (DOE/ID-22129), 116 p. 
c

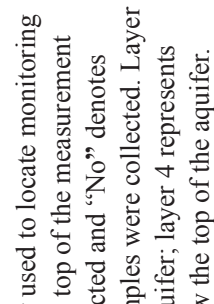

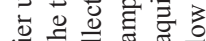

营

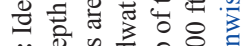

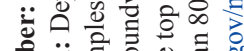

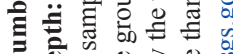

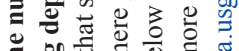

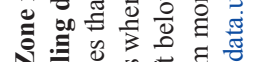

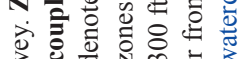

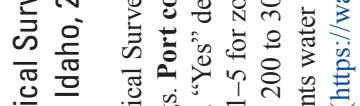

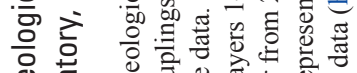

๑

ญे

का

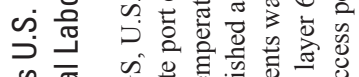

ฆ ত

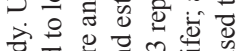

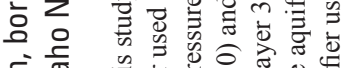

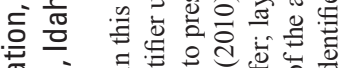

돈

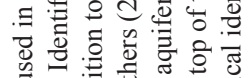

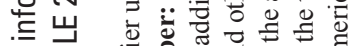

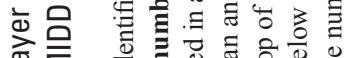

즈

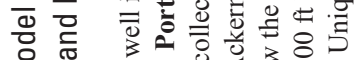

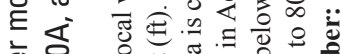

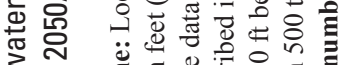

合

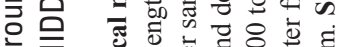

ธ

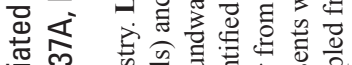

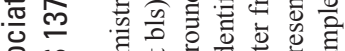

幽

๘

ত ल

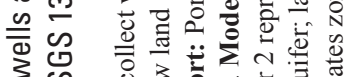

品

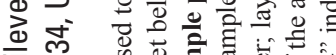

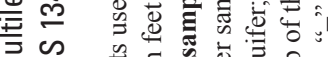

ही

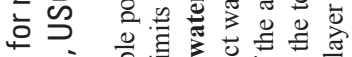

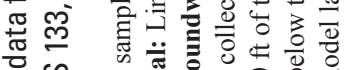

ऽ

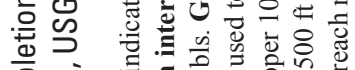

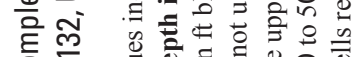

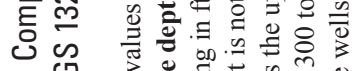

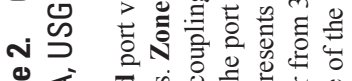

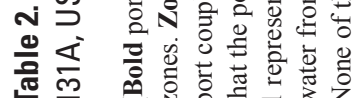

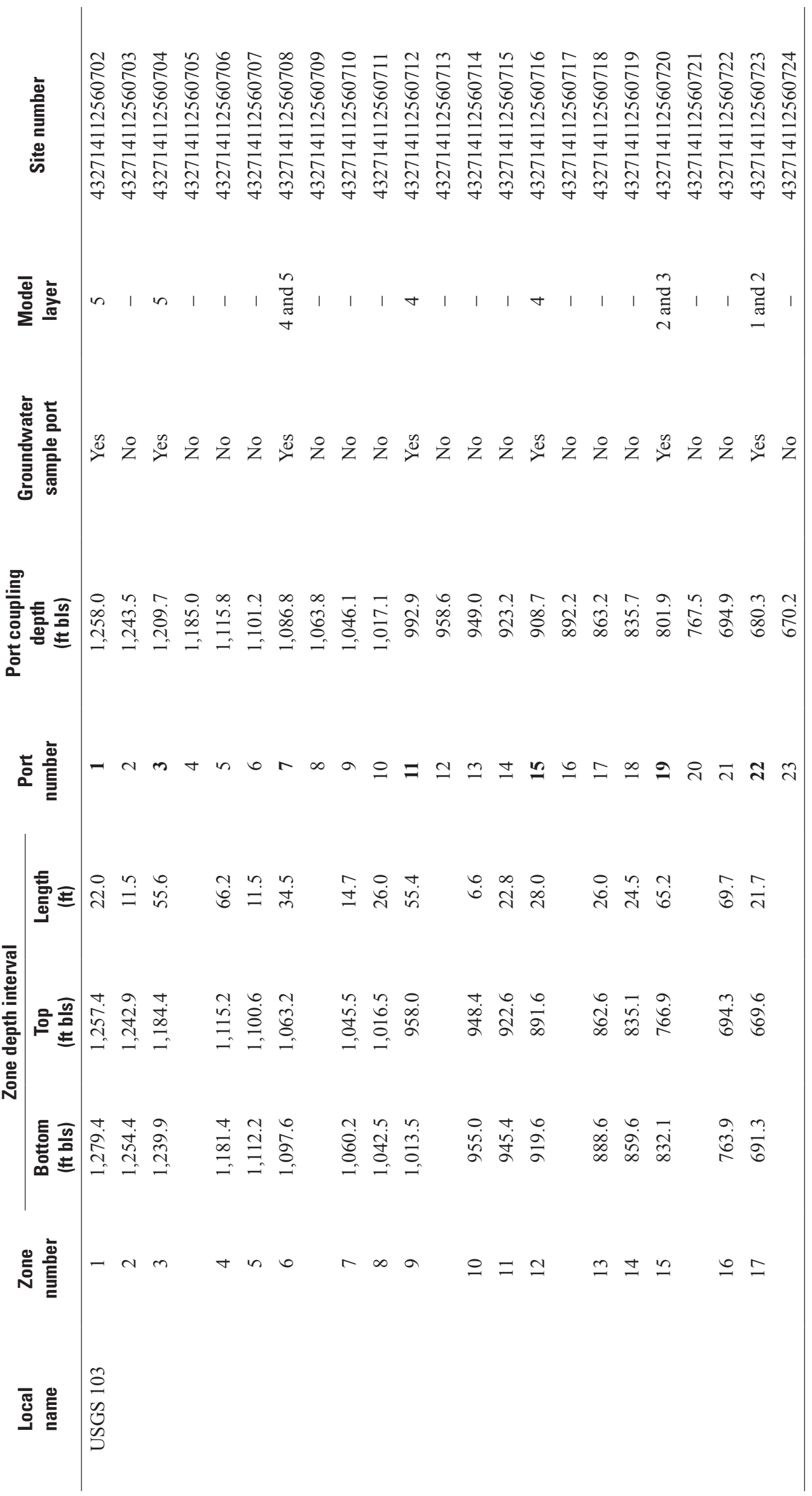




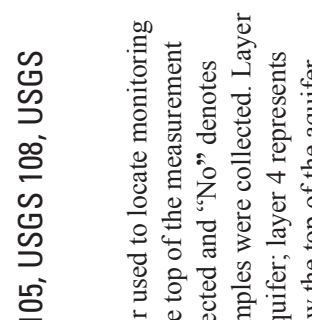

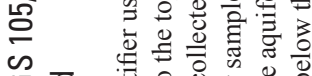

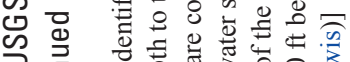

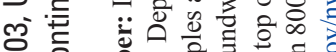

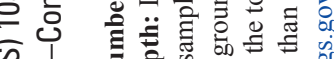

की.

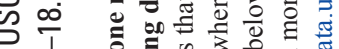

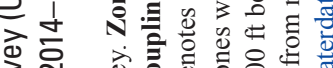

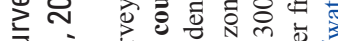

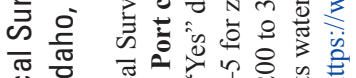

然品品

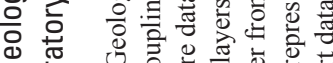

๑苛 D

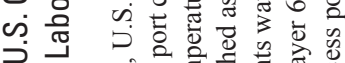

\%

응 음

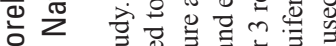

으 to

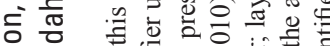

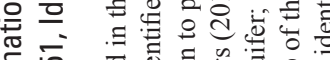

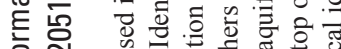

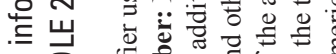

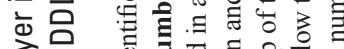

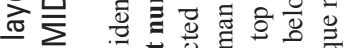

ब

당

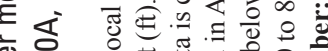

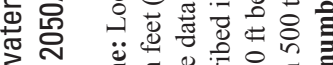

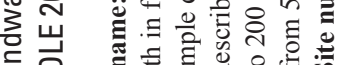

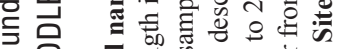

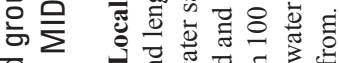

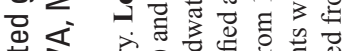

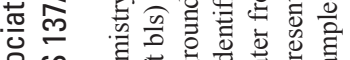

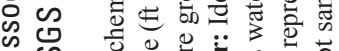

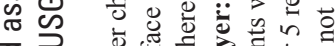

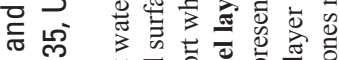

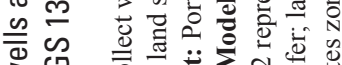

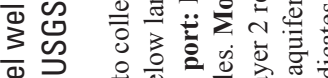

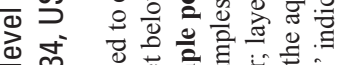

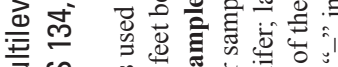

至出

은 出

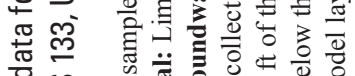

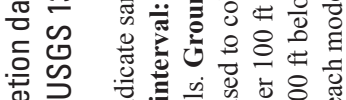

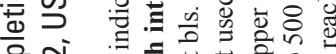

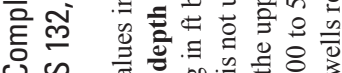

U

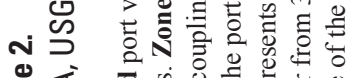

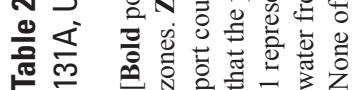

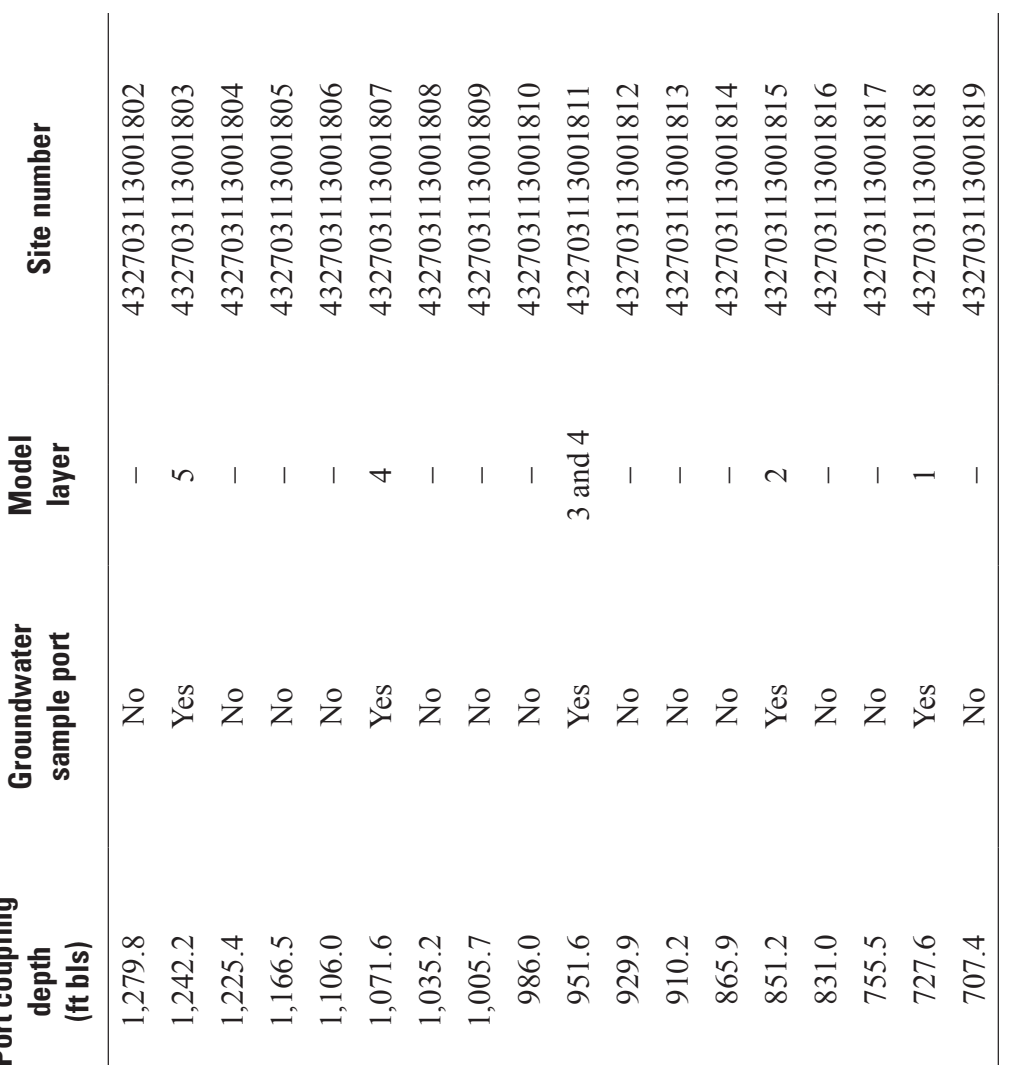

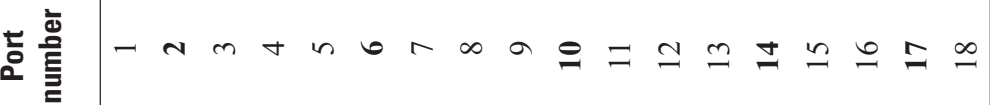

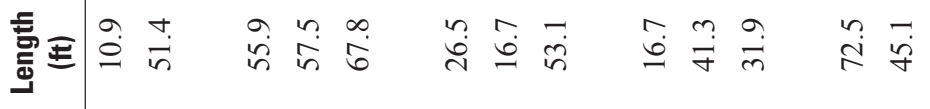

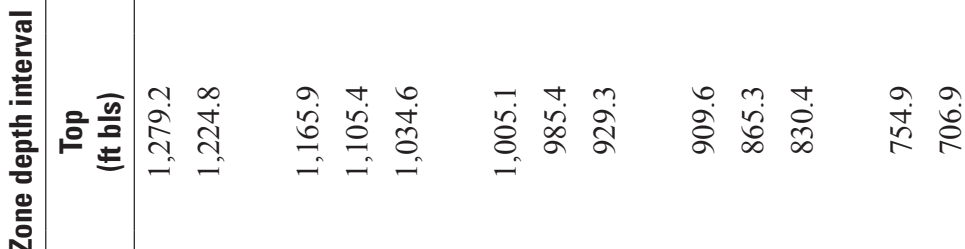

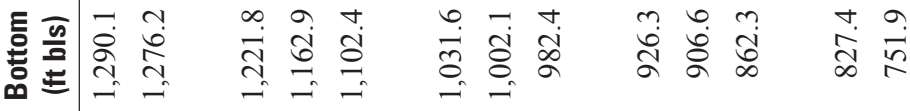

言高 $-n$ m

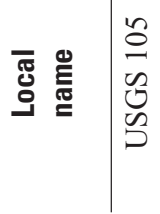




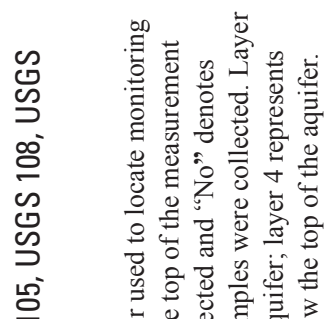

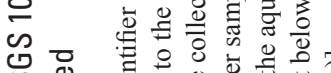

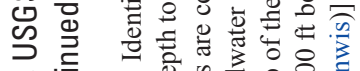

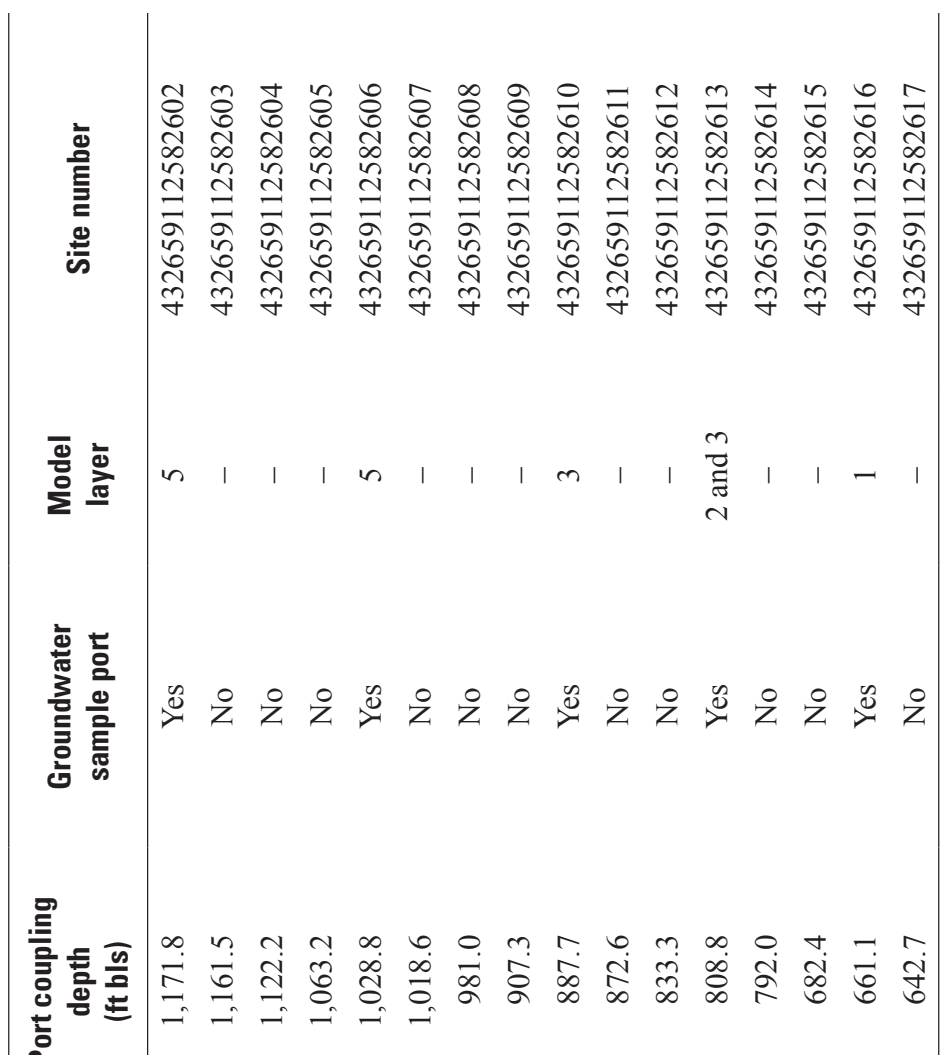

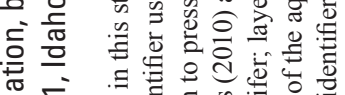

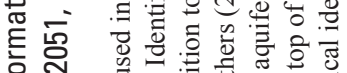

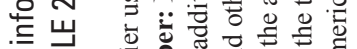

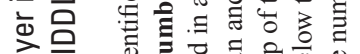

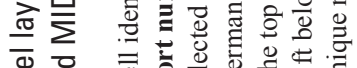

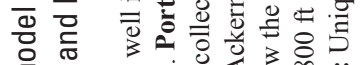

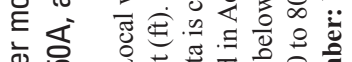

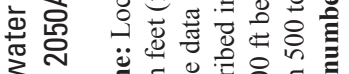

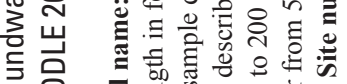

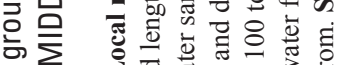

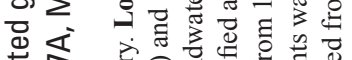

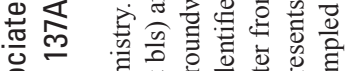

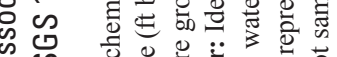

๘

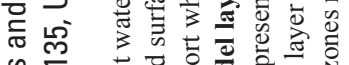

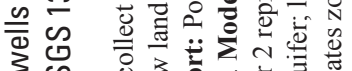

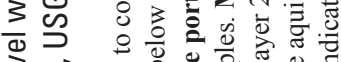

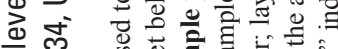

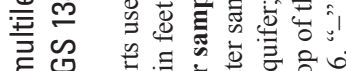

현.

匹

苋 向到

등 जी

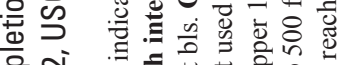

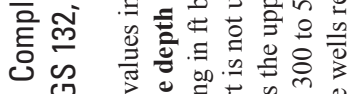

ن 出

元

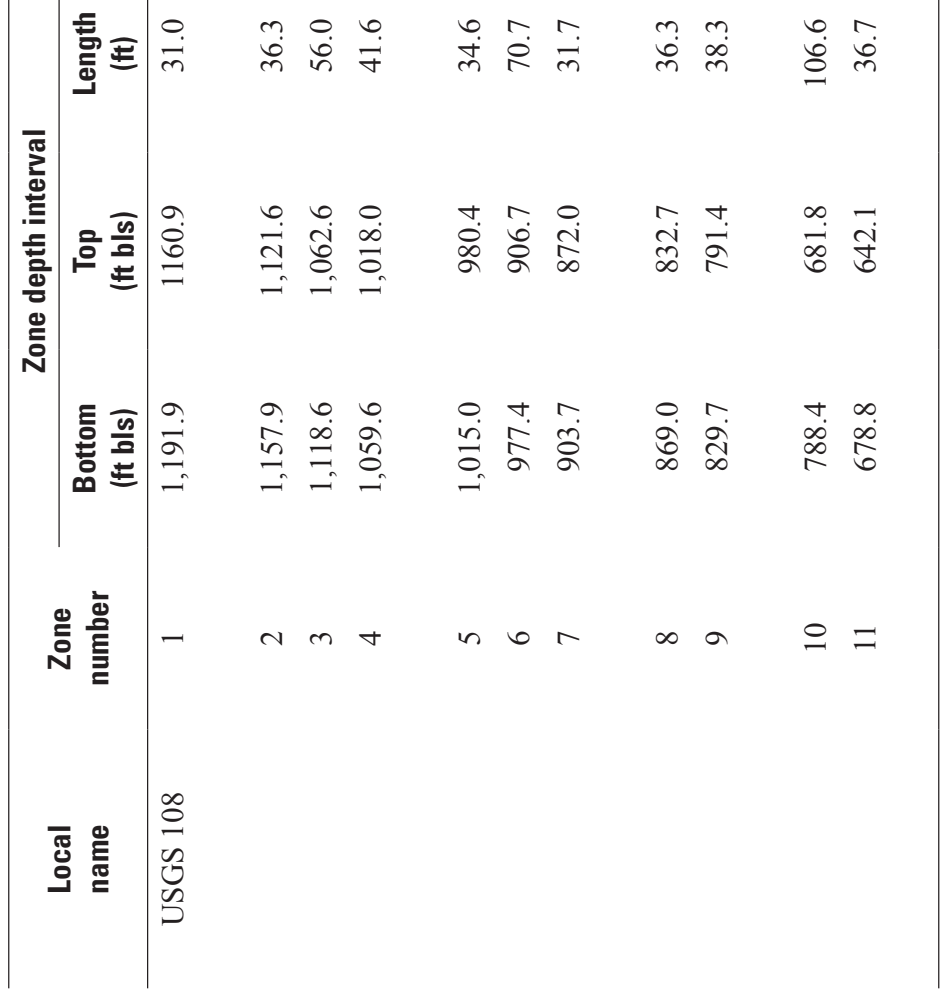




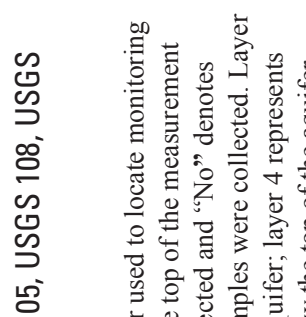

ᄂ

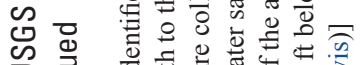

包记

๙ั

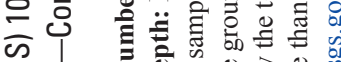

乌

మొ

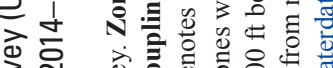

য

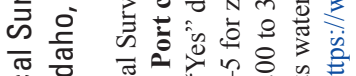

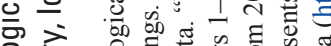

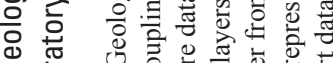

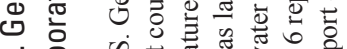

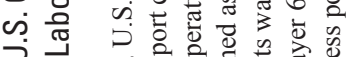

क जि

生.등

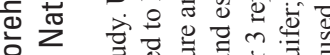

은

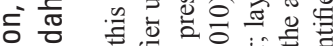

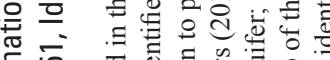

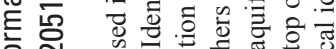

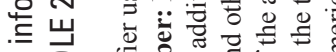

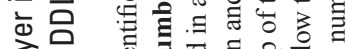

๙

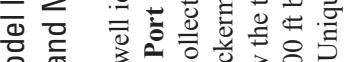

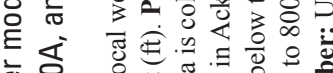

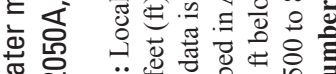

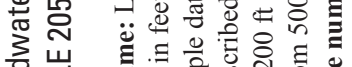

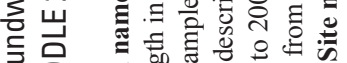

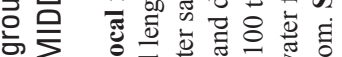

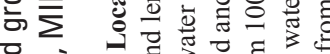

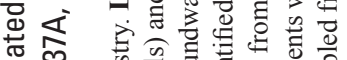

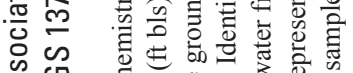

की

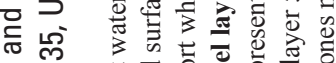

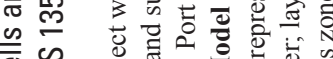

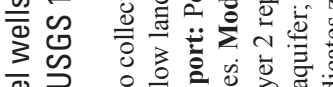

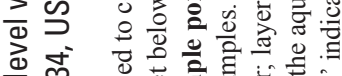

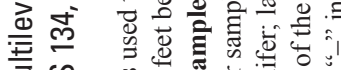

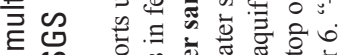

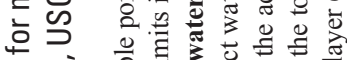

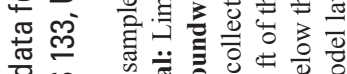

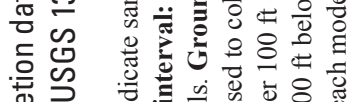

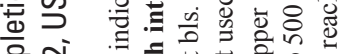

츨 尔

نं कु

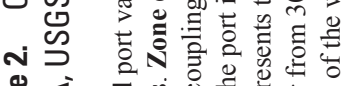

蓬

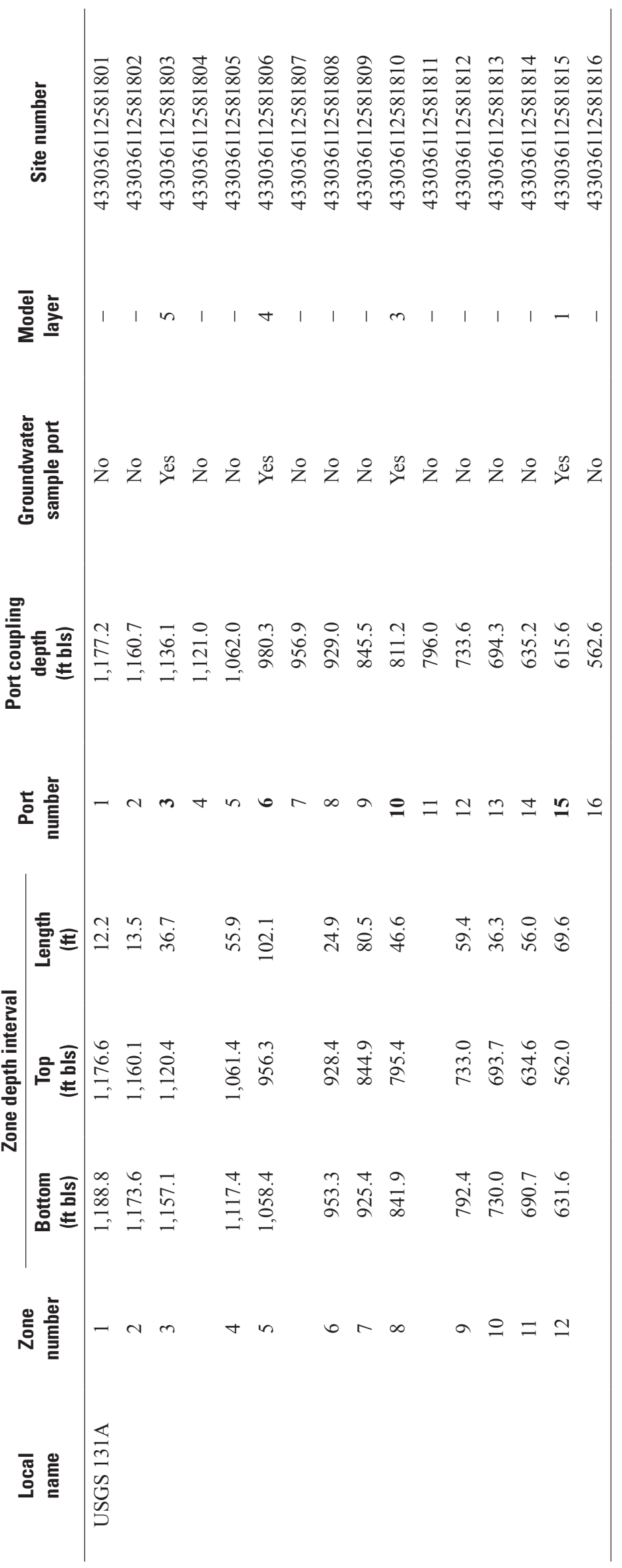




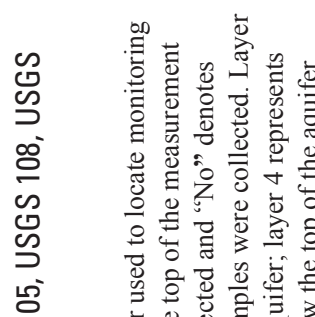

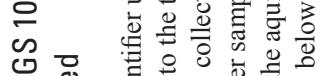

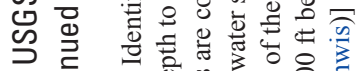

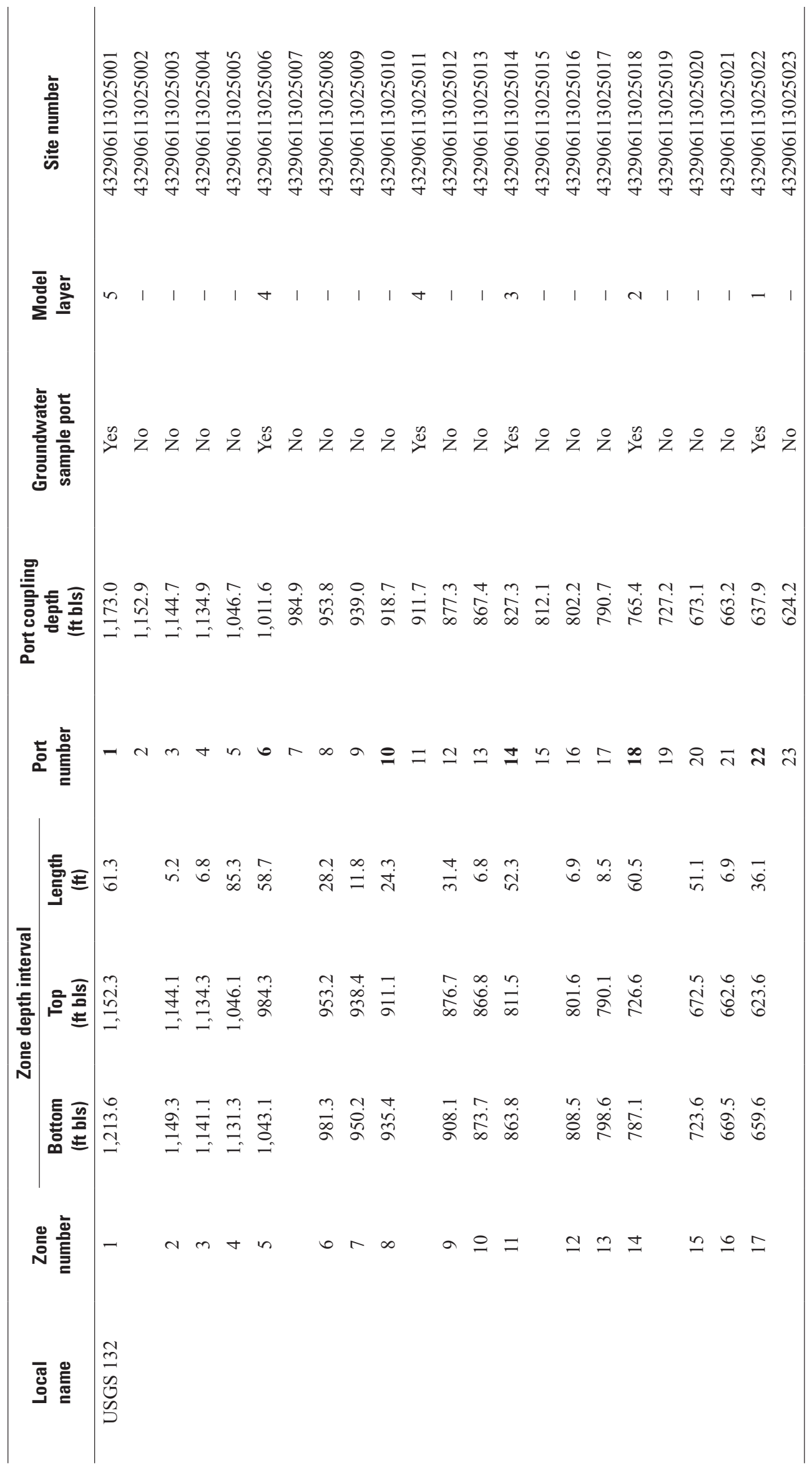


Table $2 \quad 47$

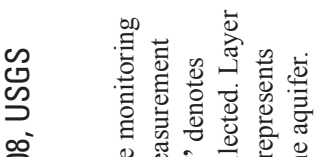

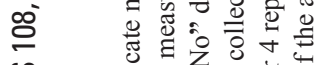

की

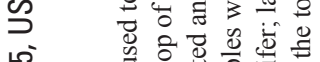

낭

可 可

乌

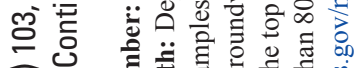

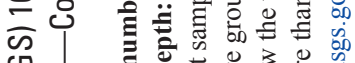

乌)

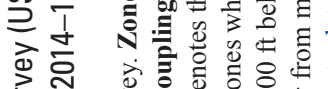

য

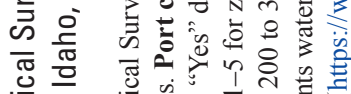

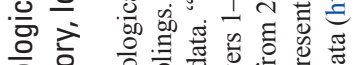

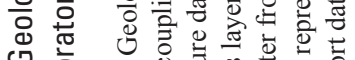

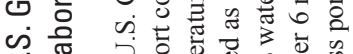

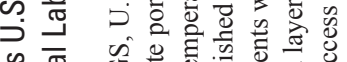

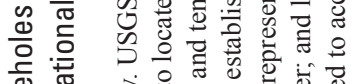

凹之

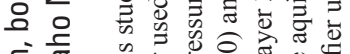

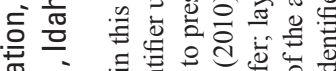

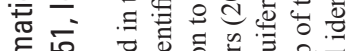

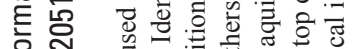

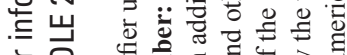

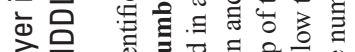

๙

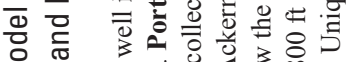

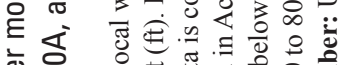

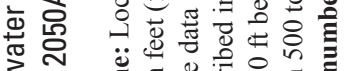

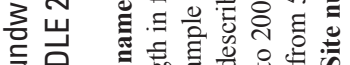

흠

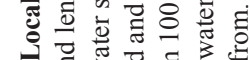

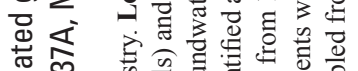

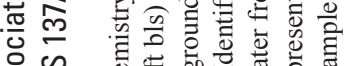

出 可

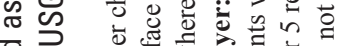

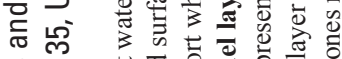

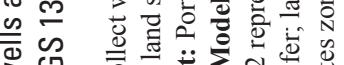

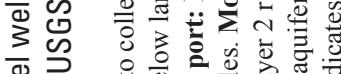

๑

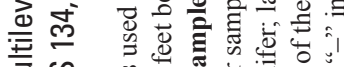

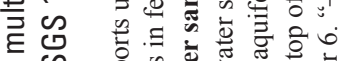

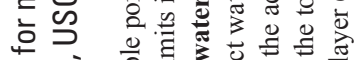

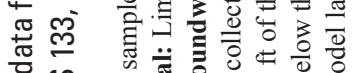

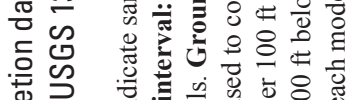

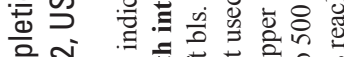

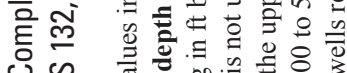

ن d

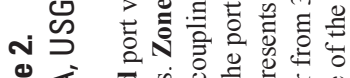

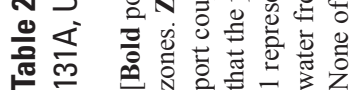

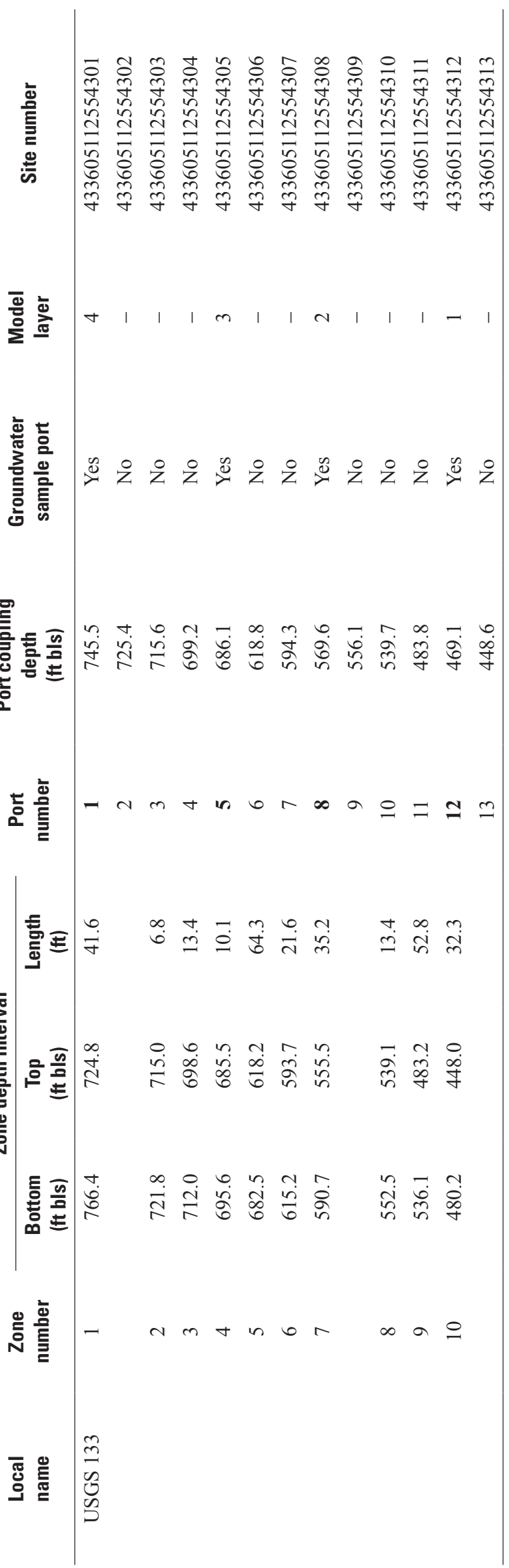




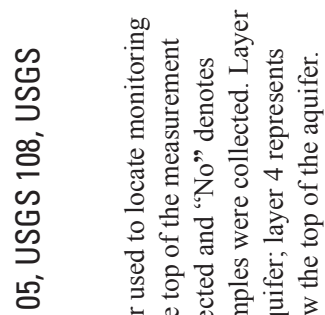

舟

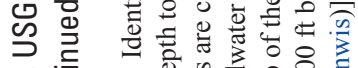

ช

की

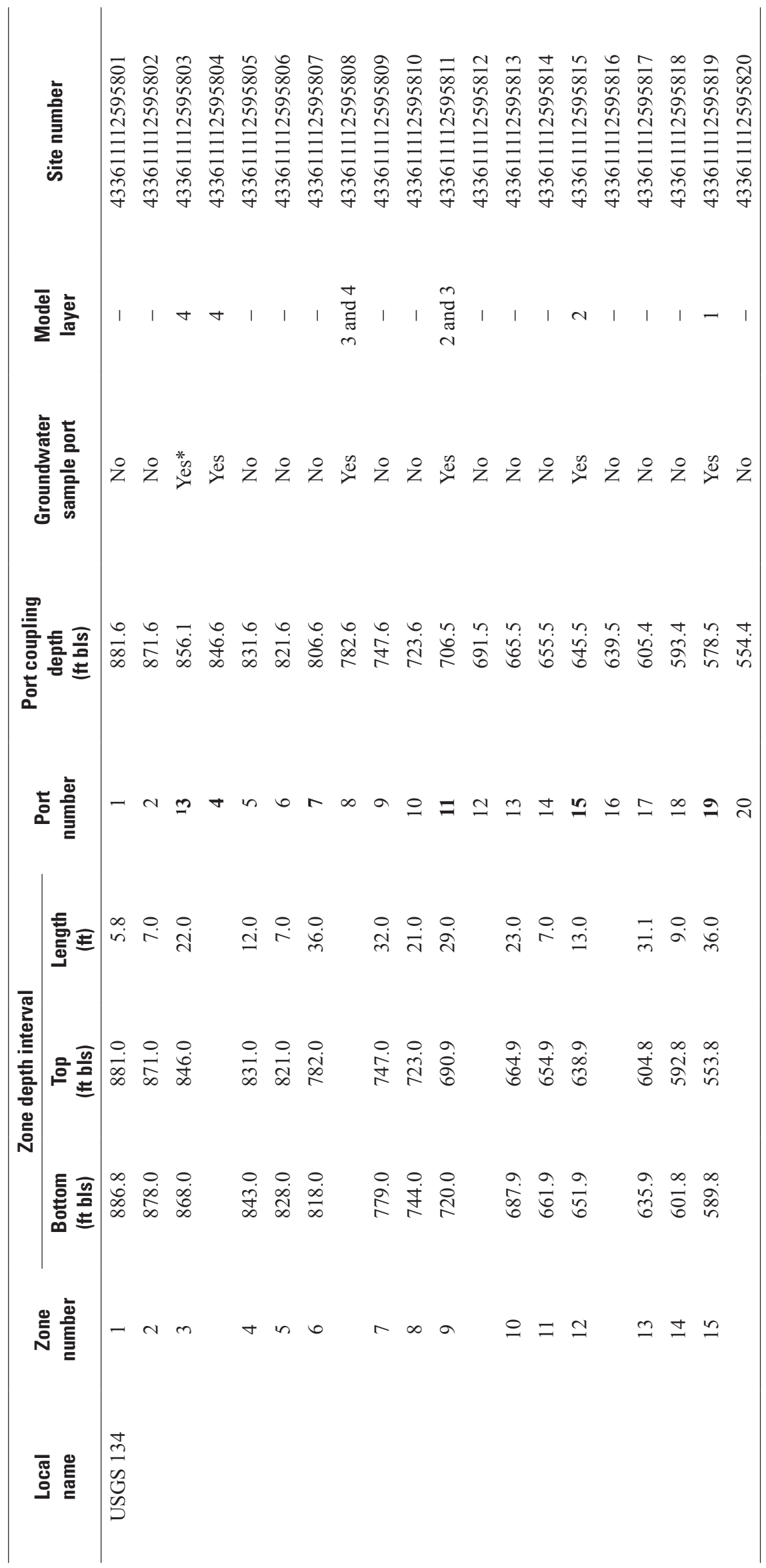




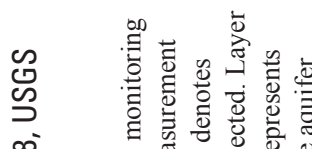

哭

包

S

เ्丶

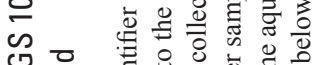

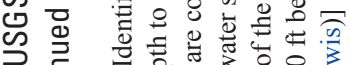

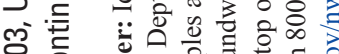

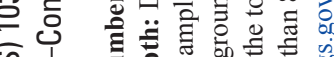

की

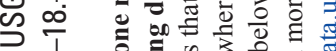

屯苛 No

য

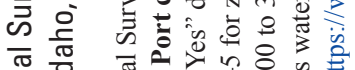

可

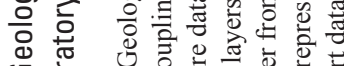

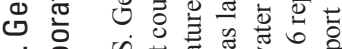

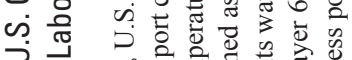

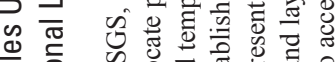

응 음

w

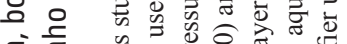

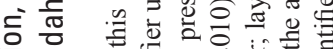

든

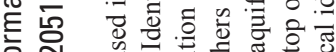

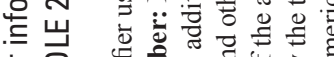

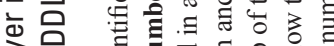

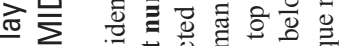

ब

元

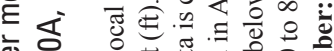

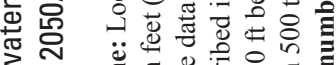

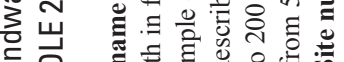

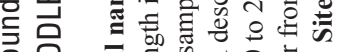

흔 至

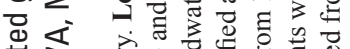

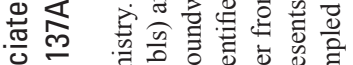

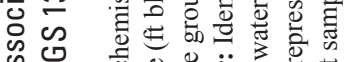

品

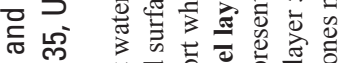

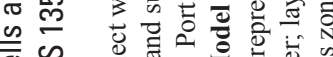

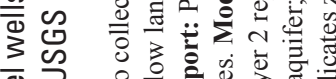

Q

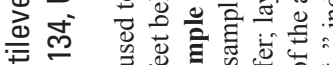

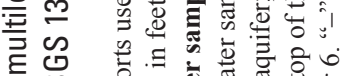

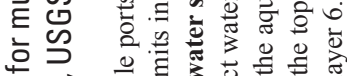

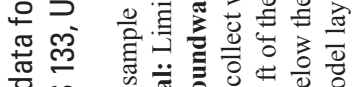

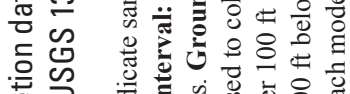

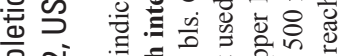

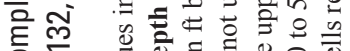

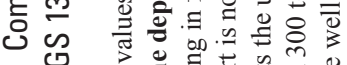

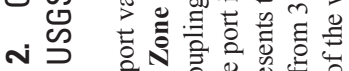

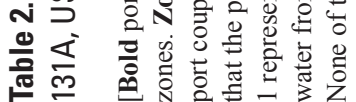

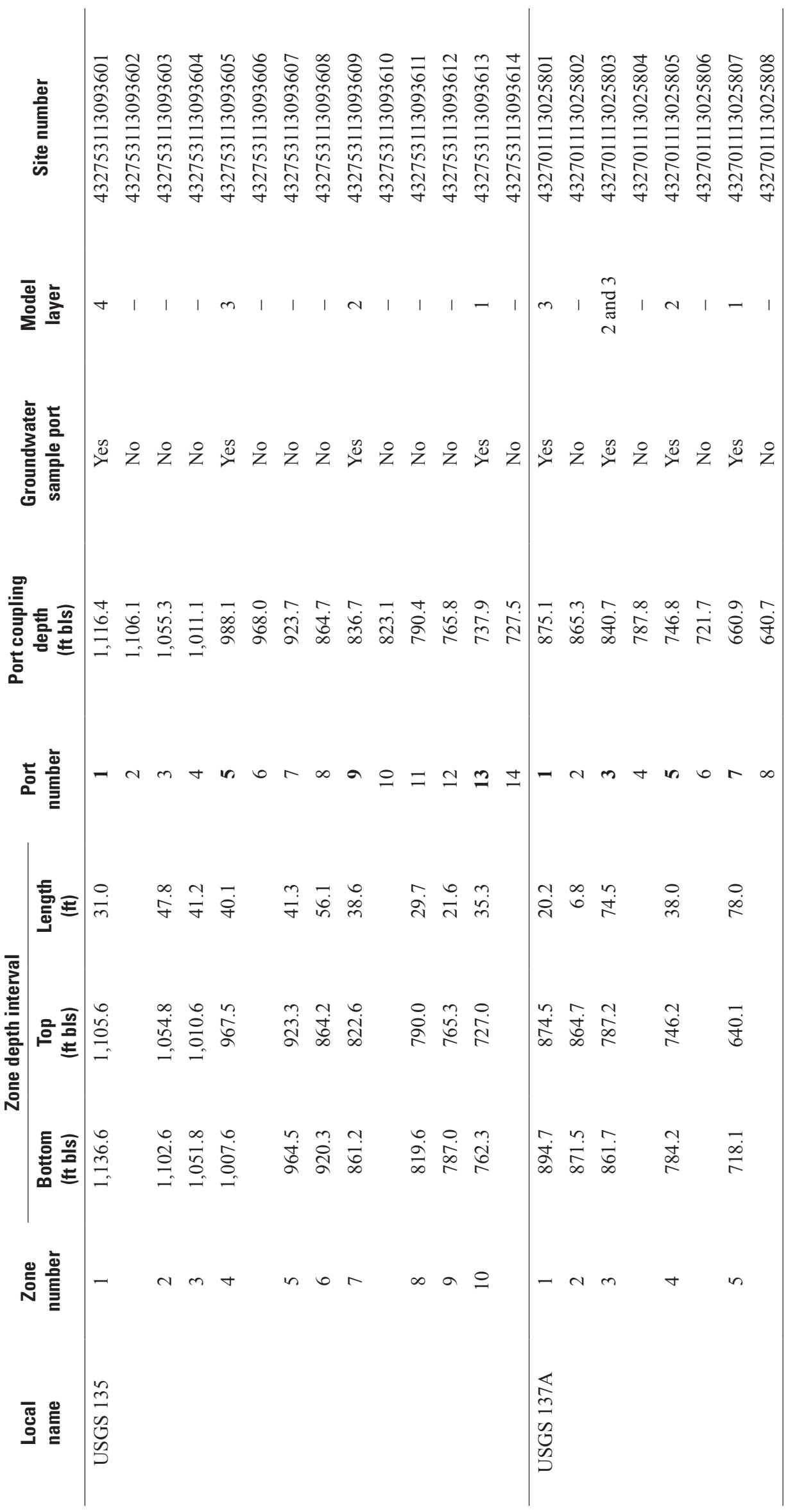




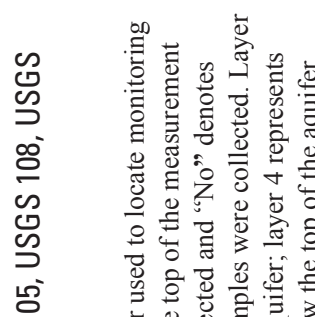

जि

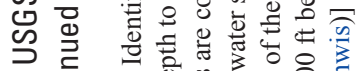

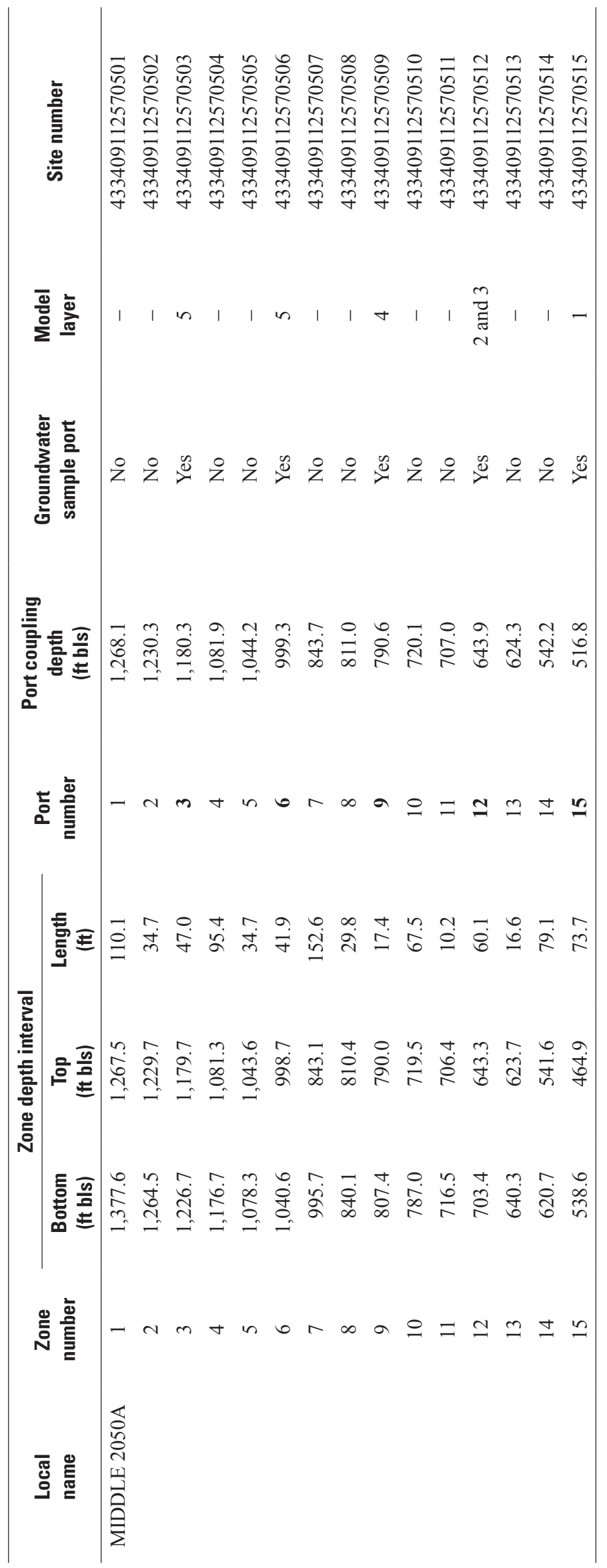
苛 을 范

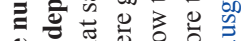

我

N: 氙记

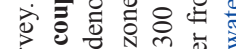

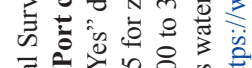

ฮึ

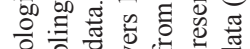

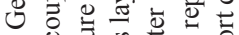

मे

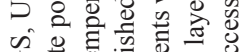

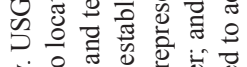

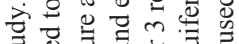

क

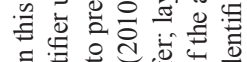

음드.

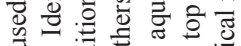

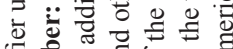

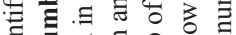

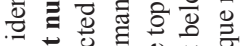

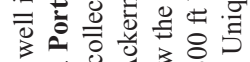

चี

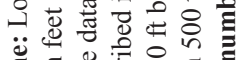

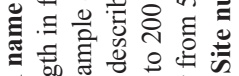

च

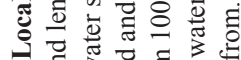

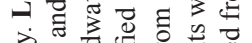

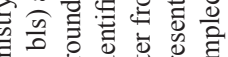

氖

ठ

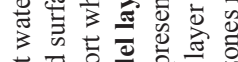

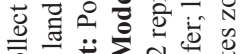

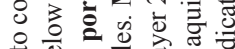

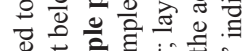

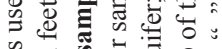

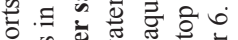

…ㄹ.

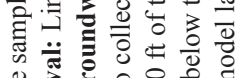

గా

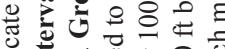

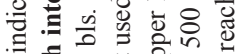

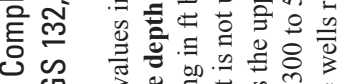

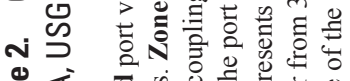

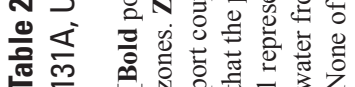




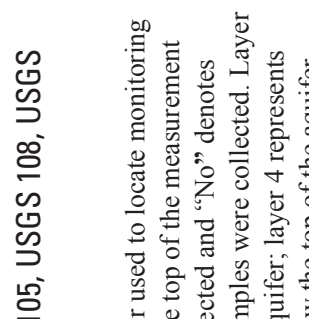

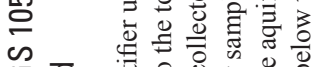

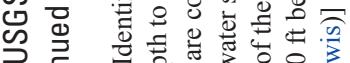

ஜํ.

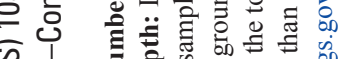

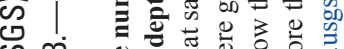

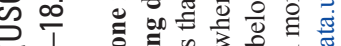

丸文 N

য N

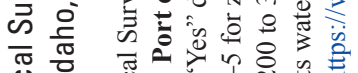

须

응 훙유을

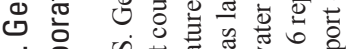

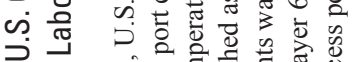

क స

응 음

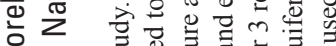

으

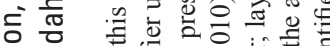

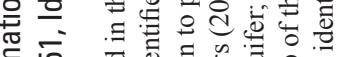

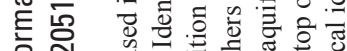

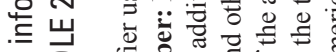

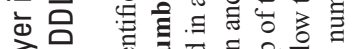

๙

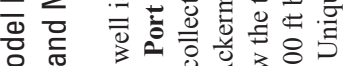

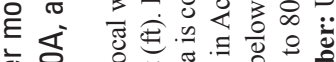

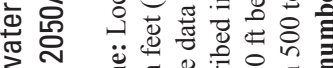

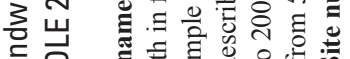

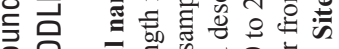

흔

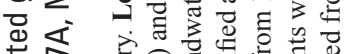

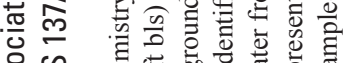

出 可

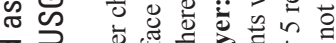

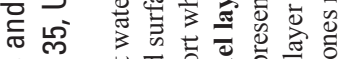

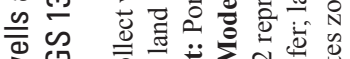

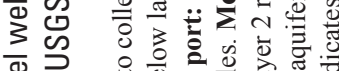

品

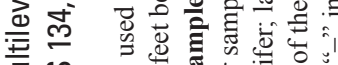

至出

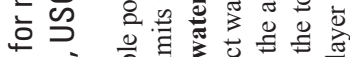

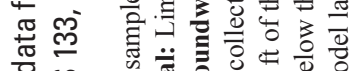

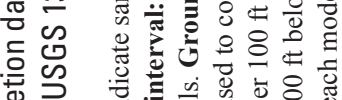

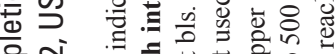

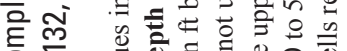

公

小

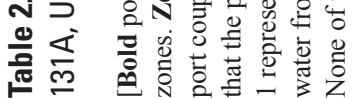

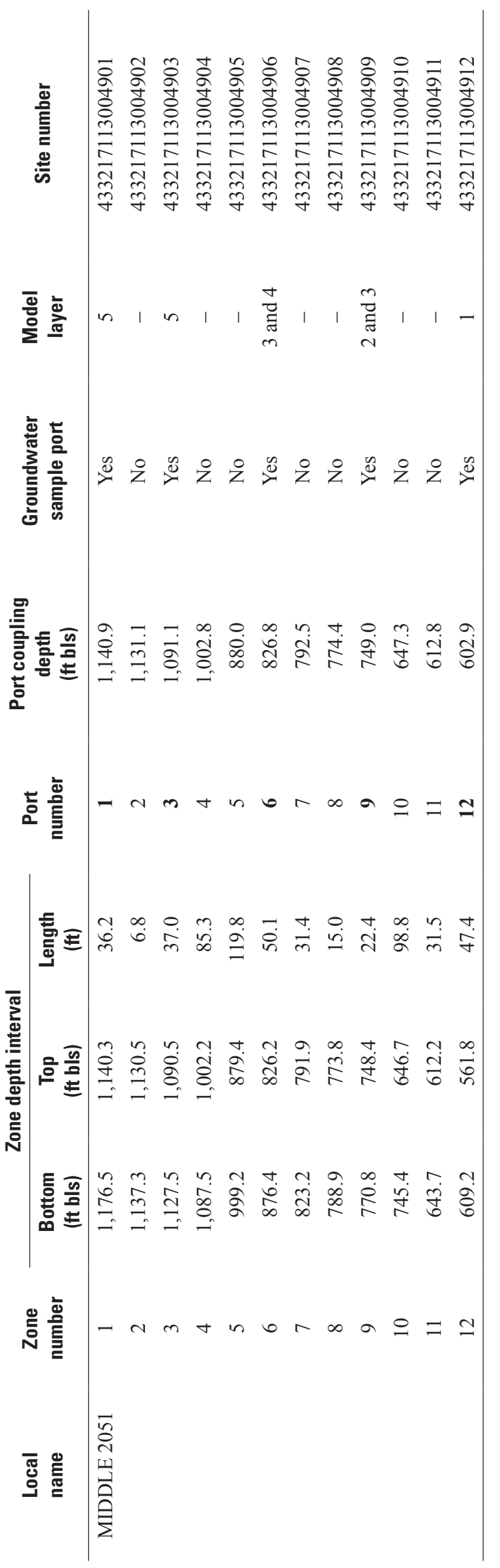




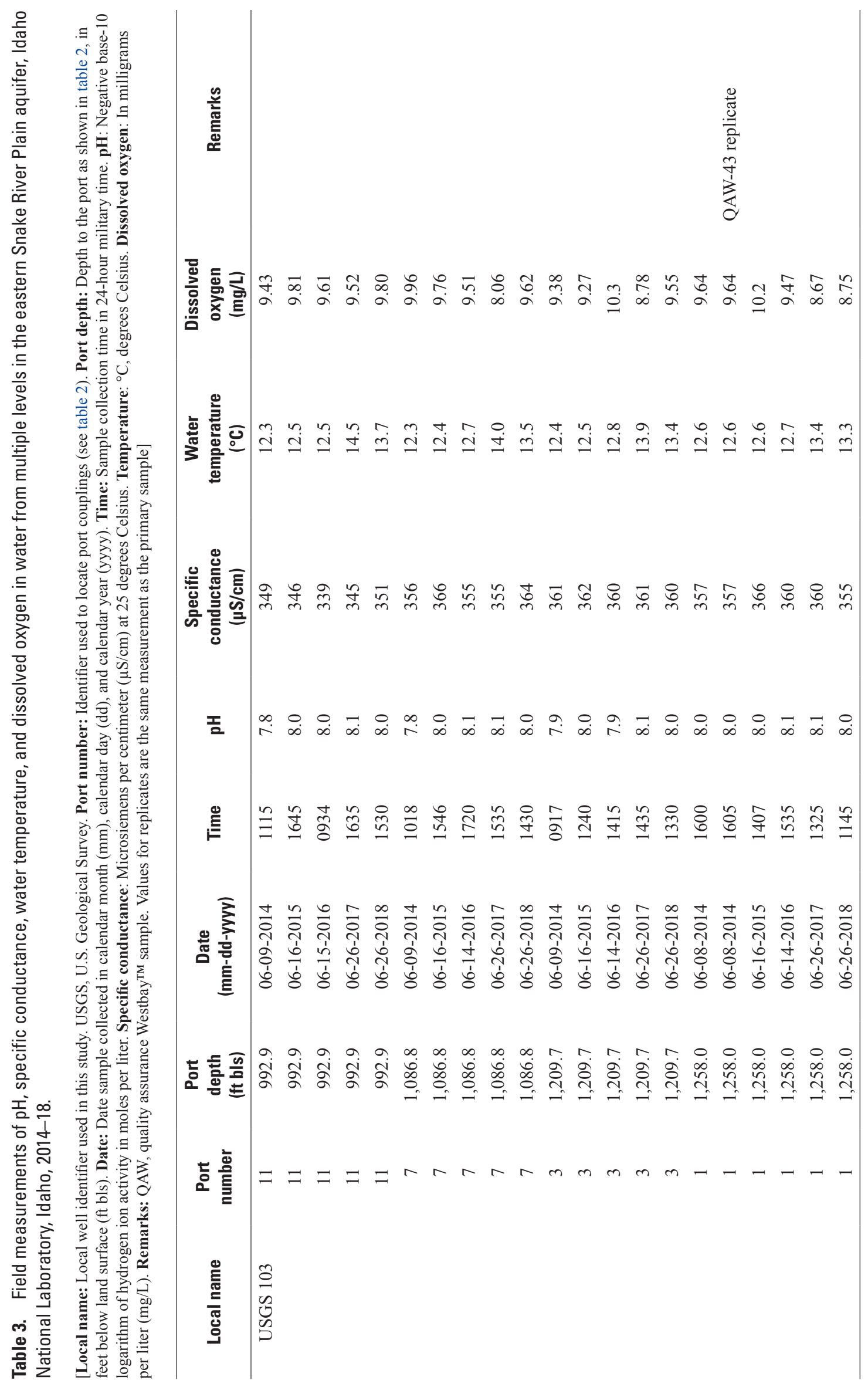




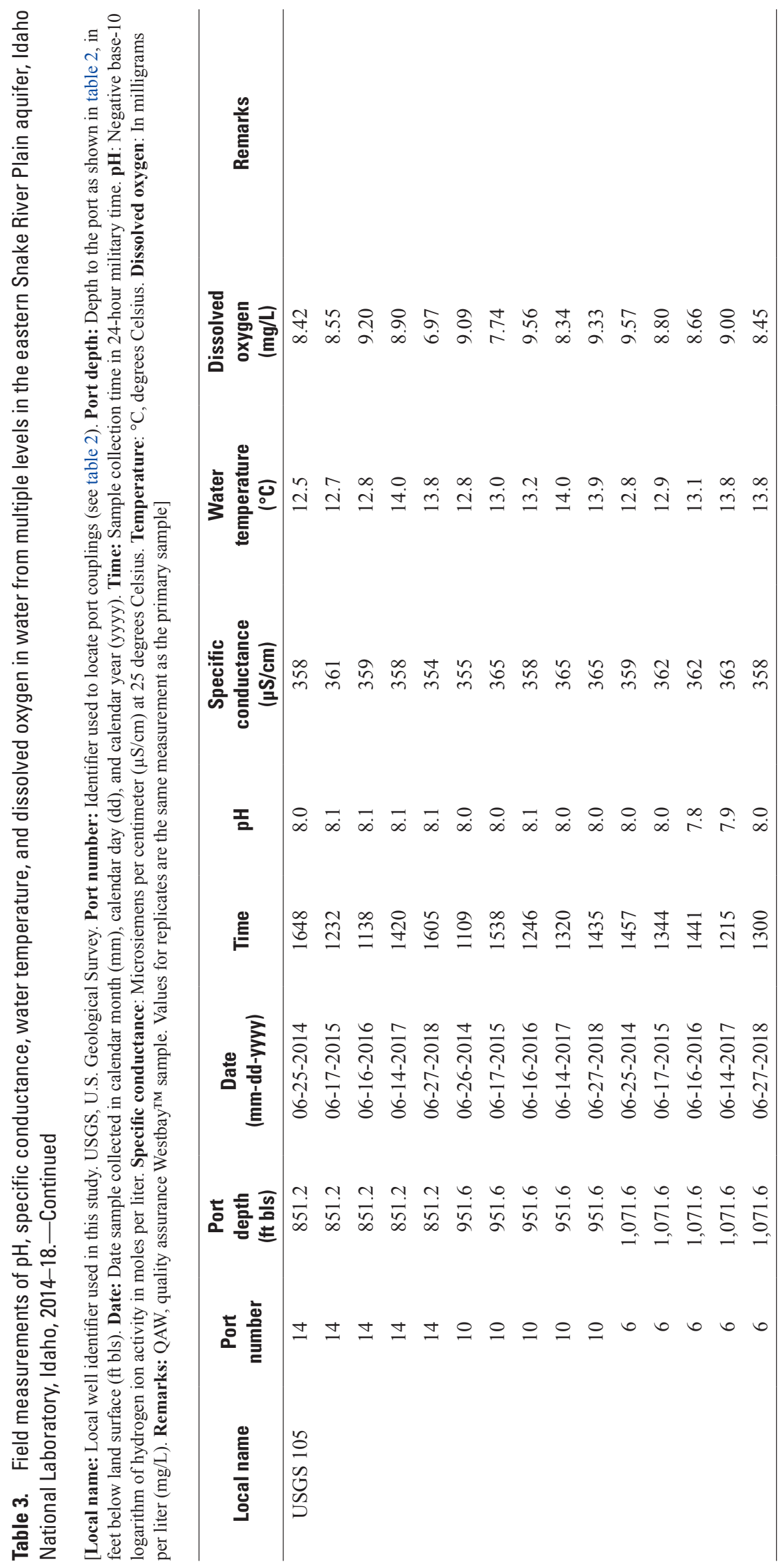




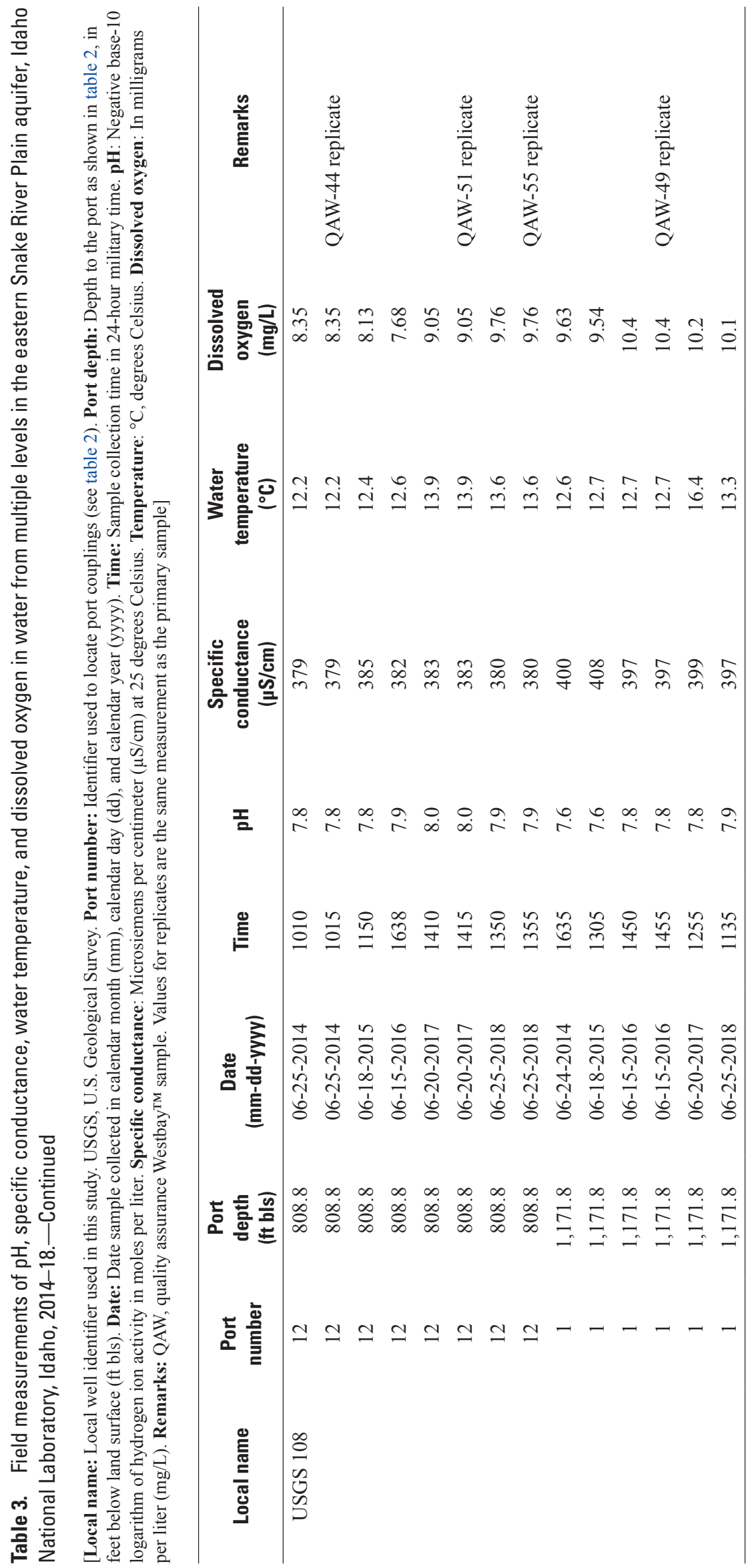




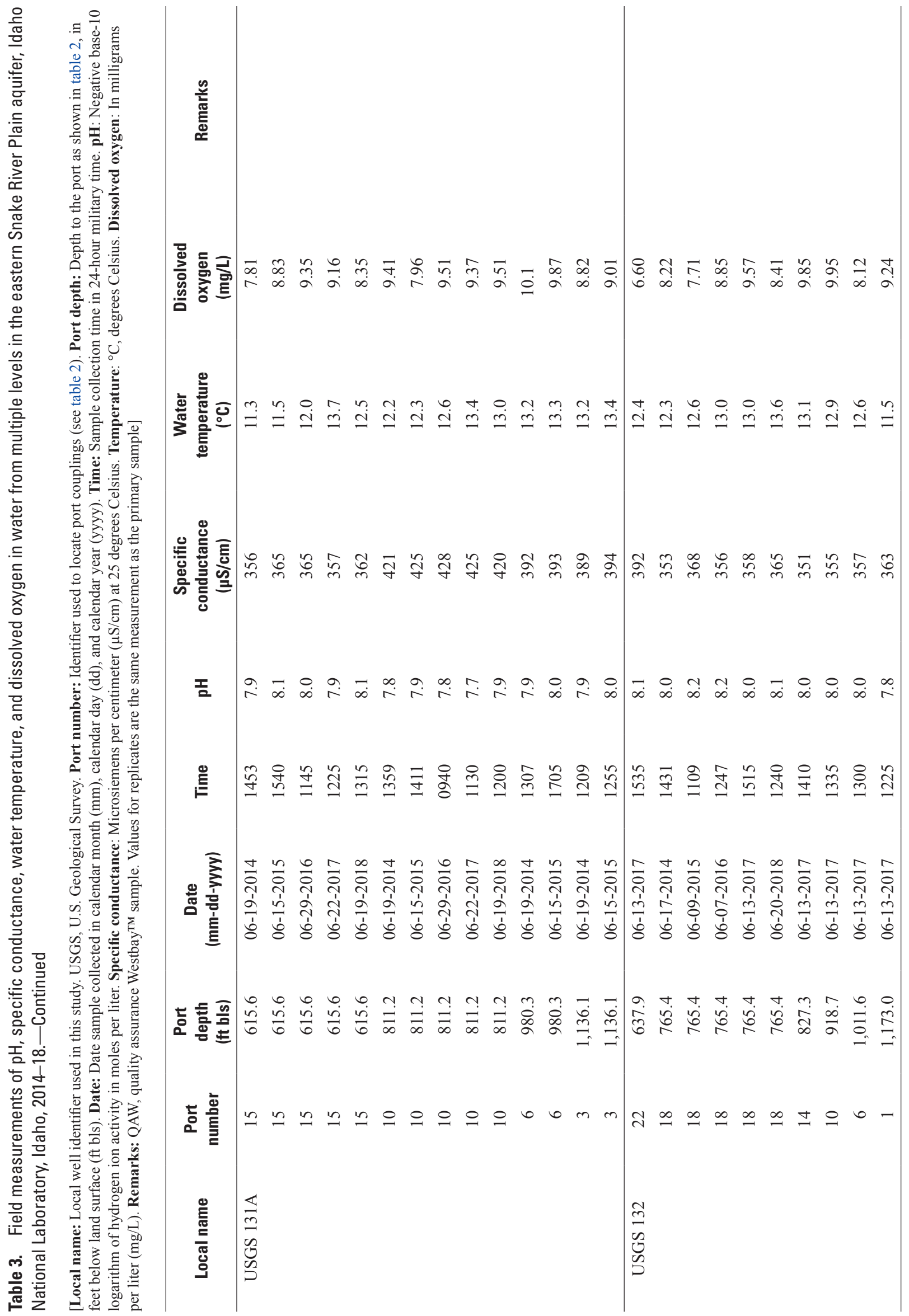




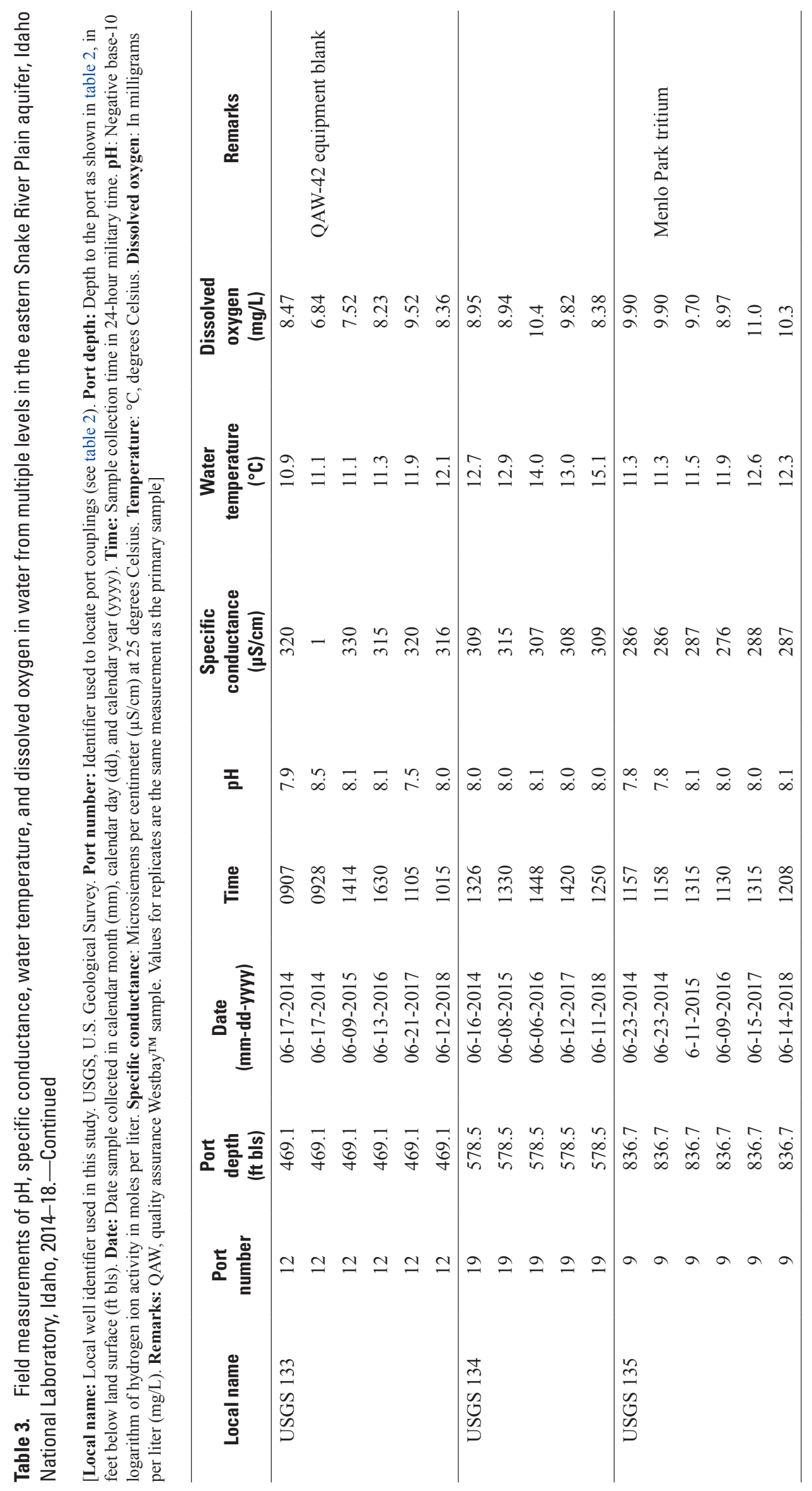




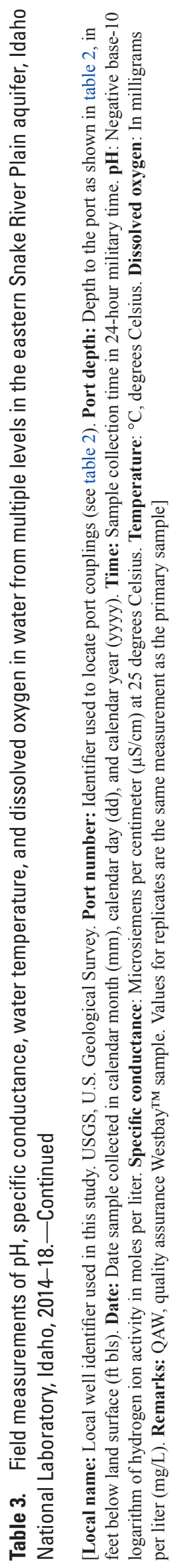

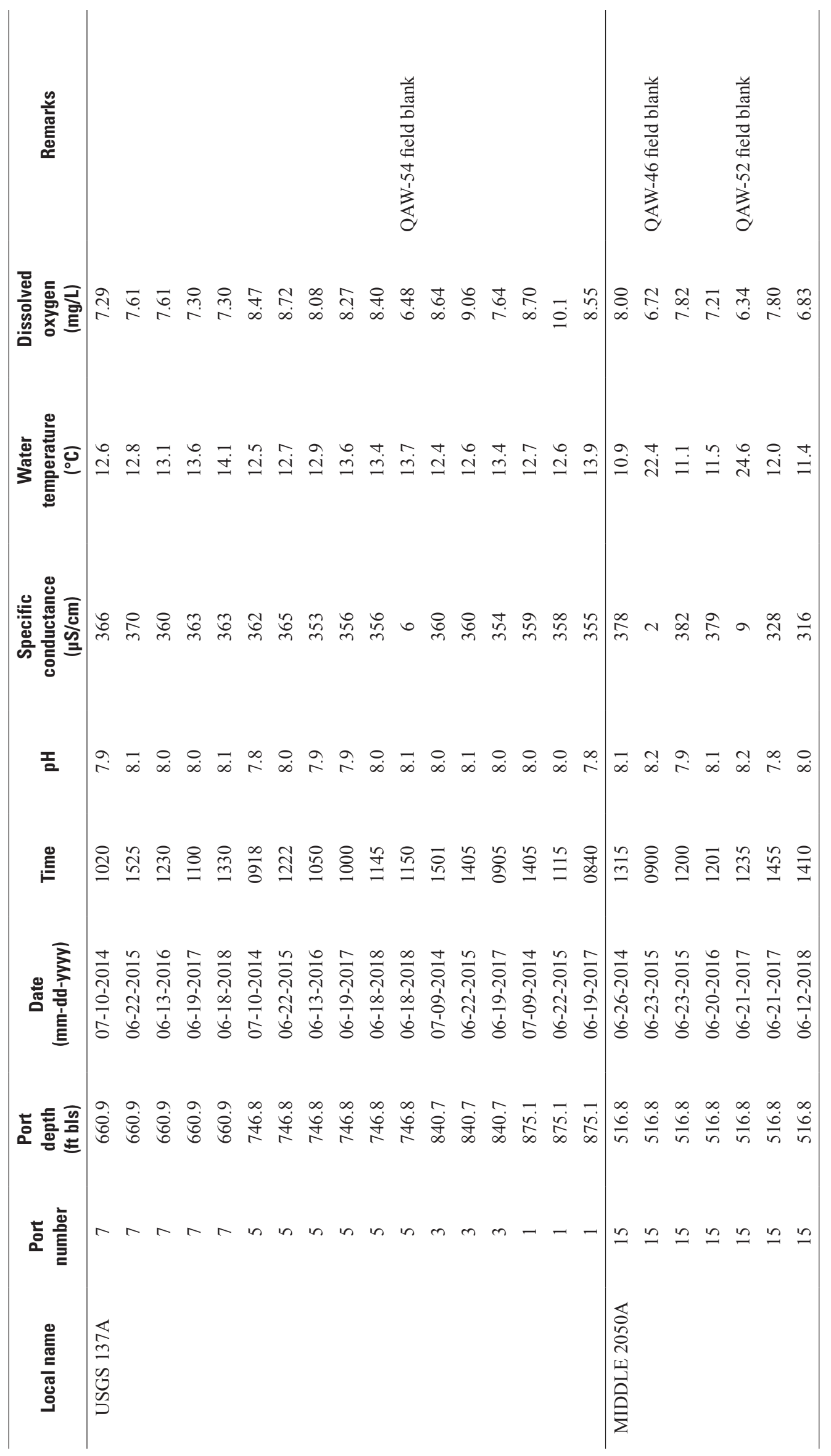




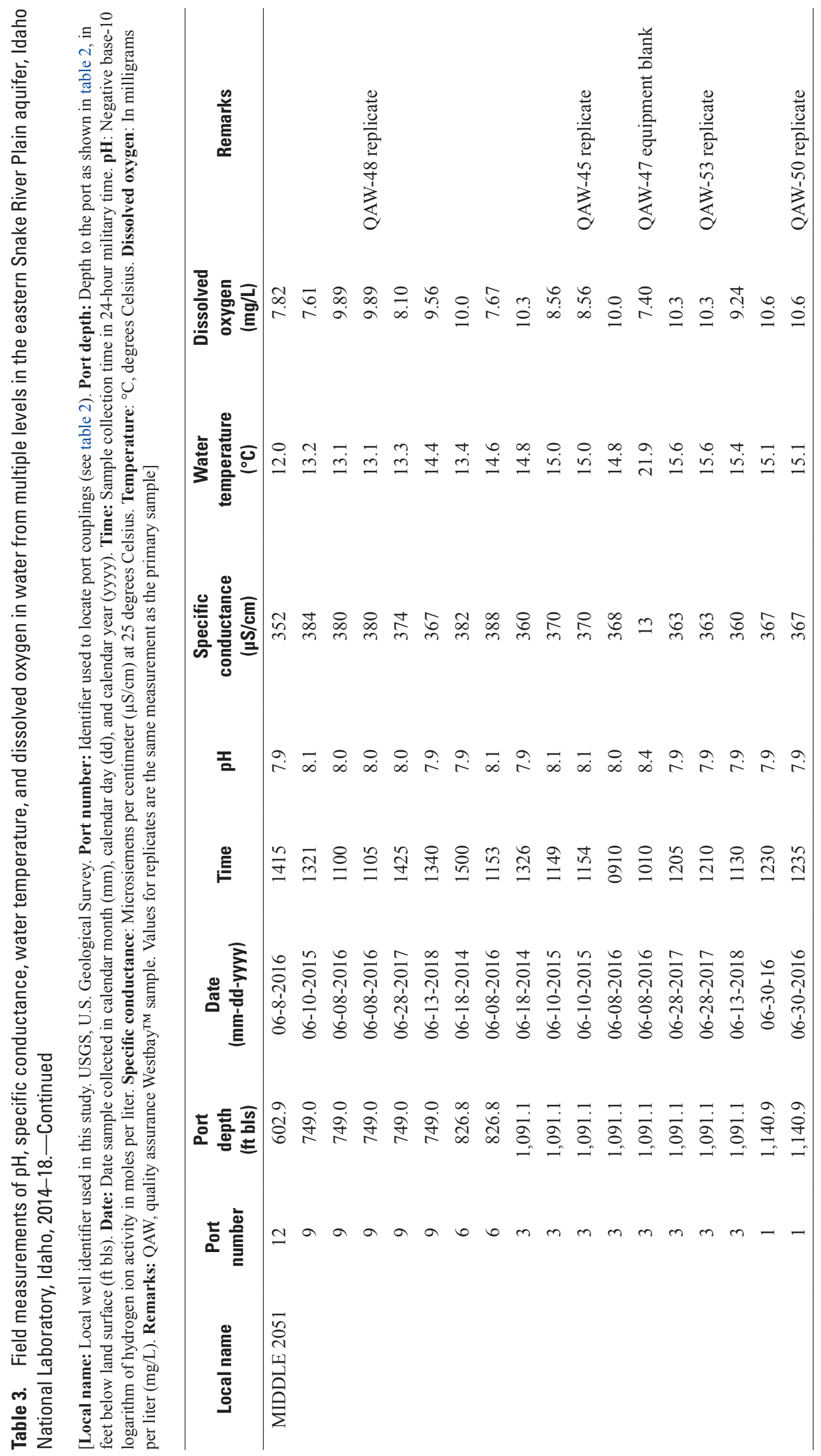




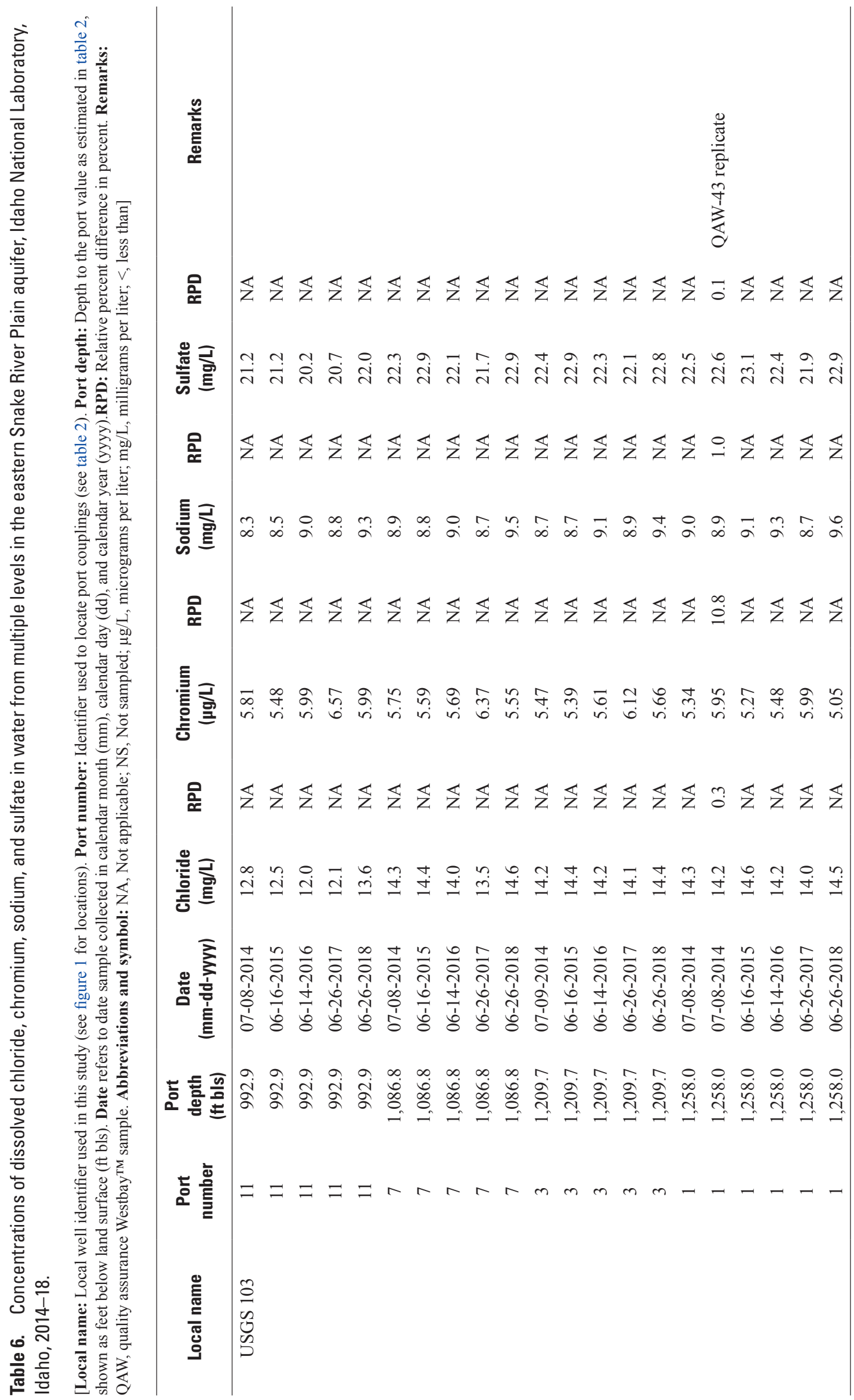




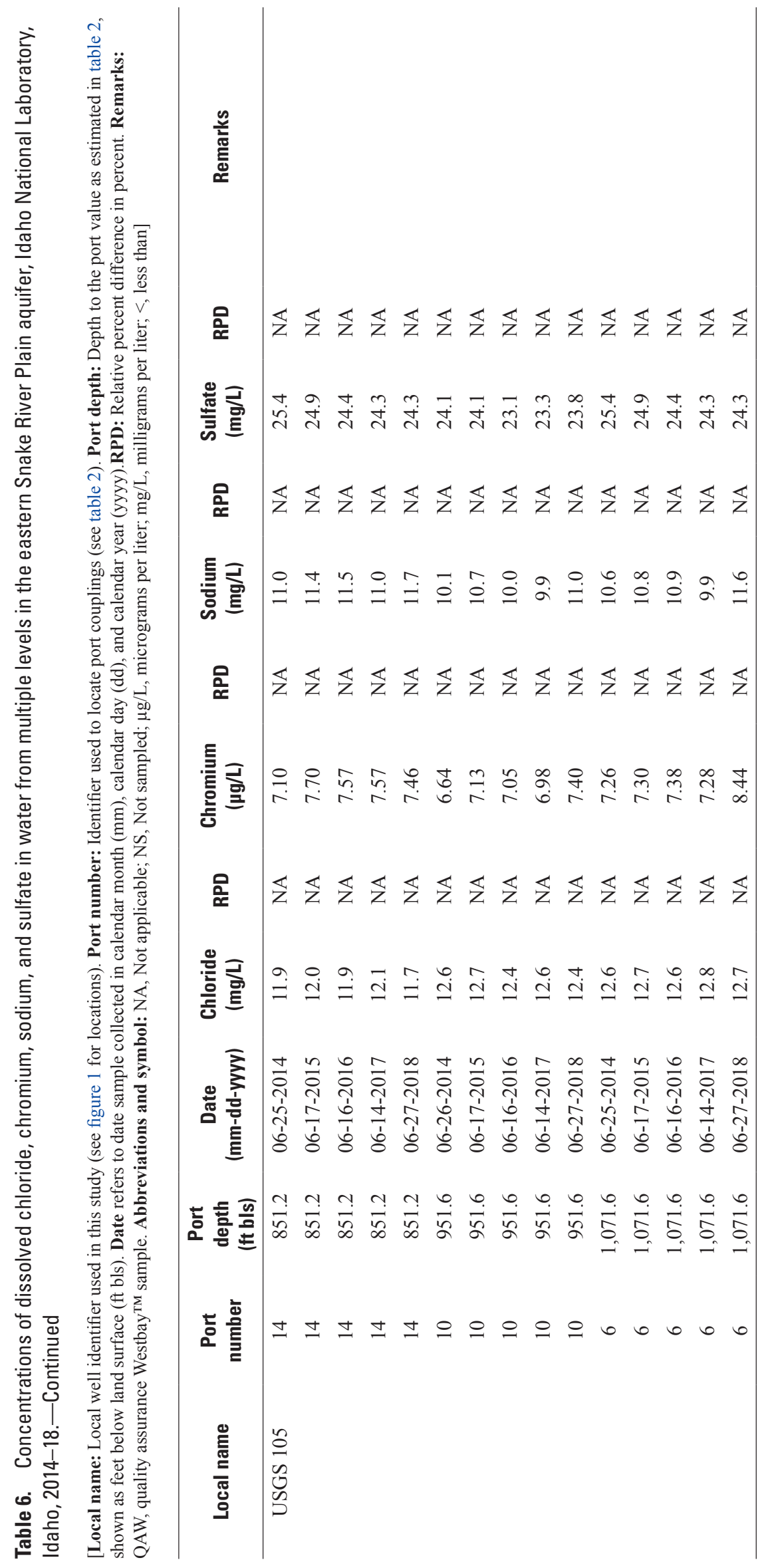




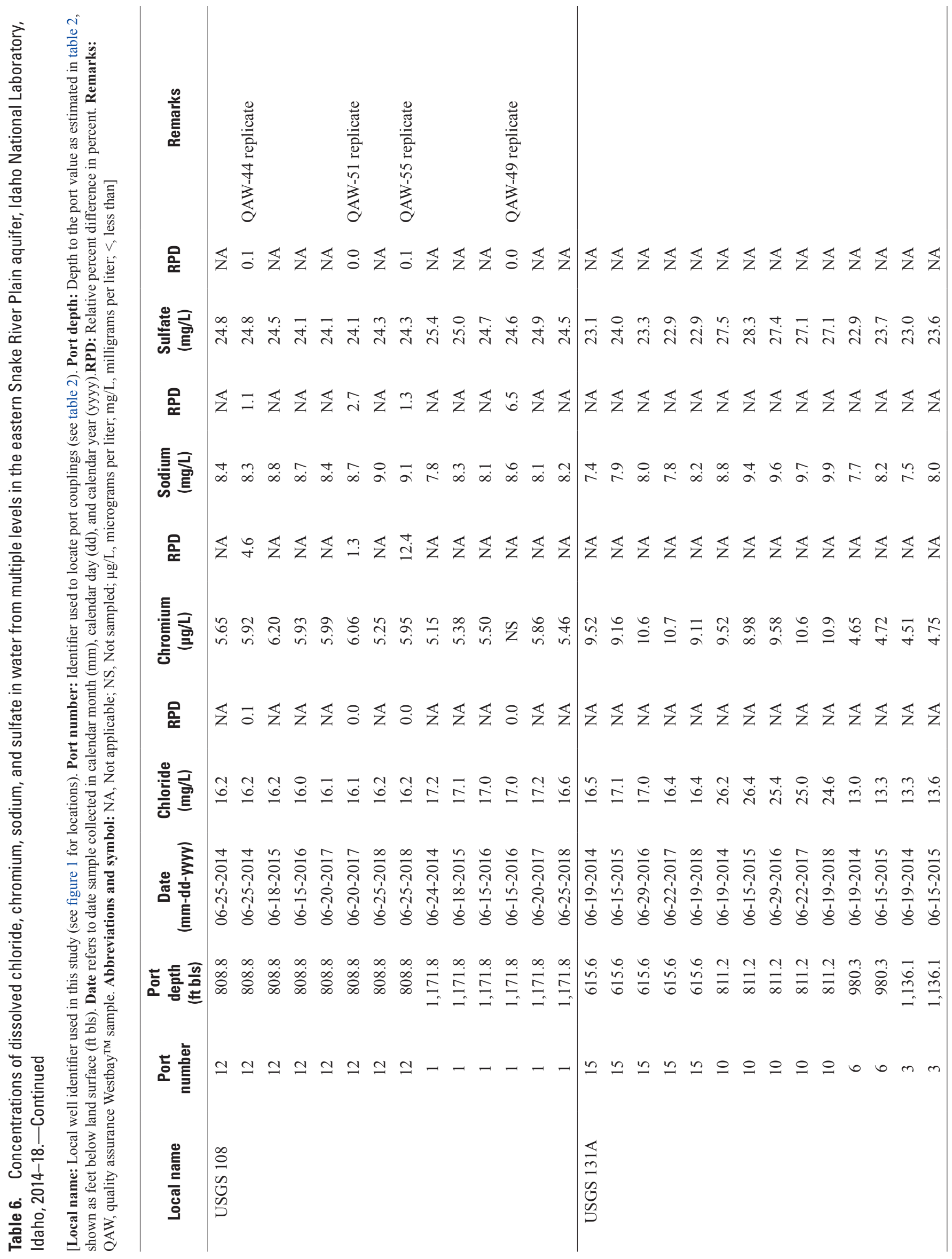




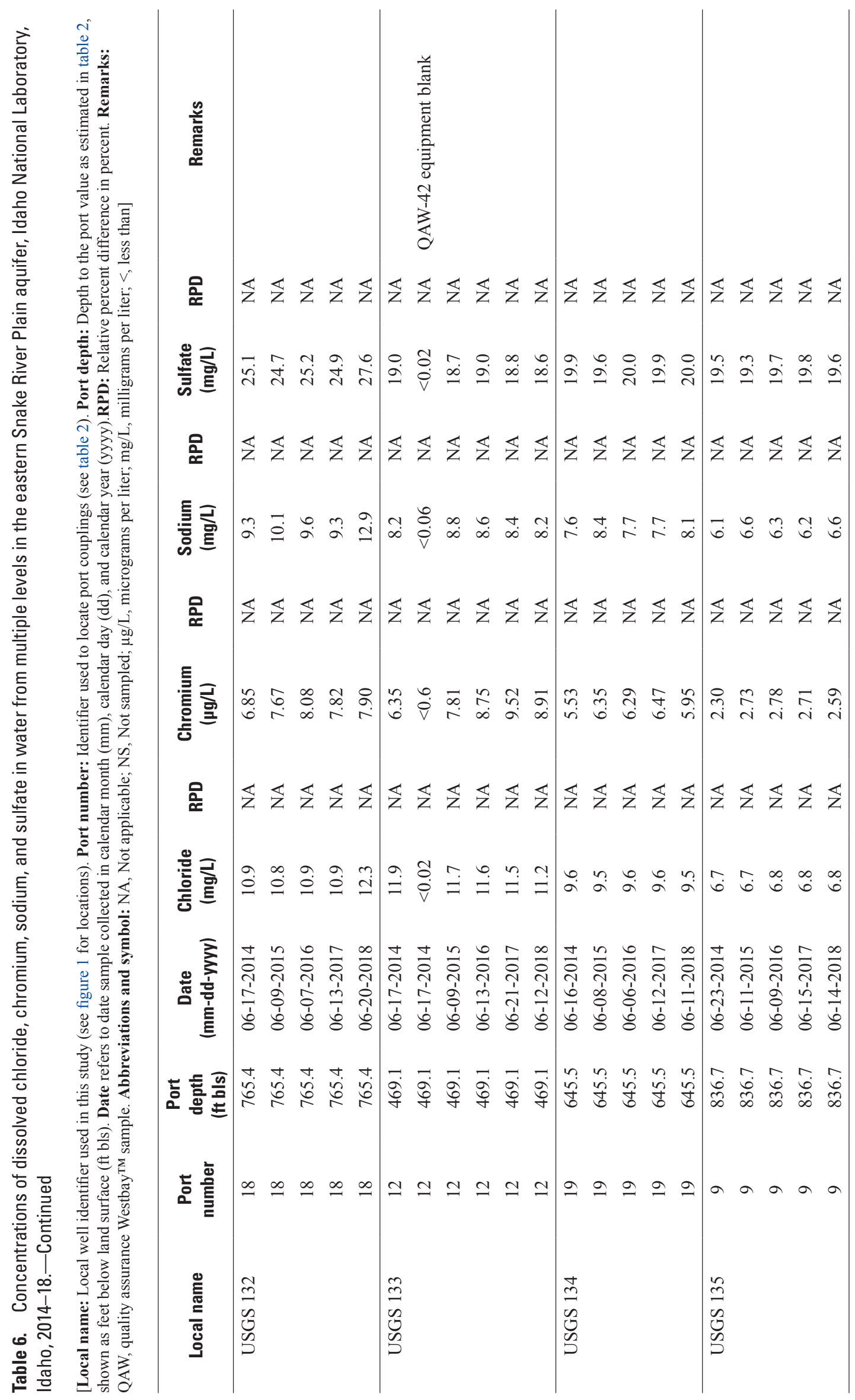




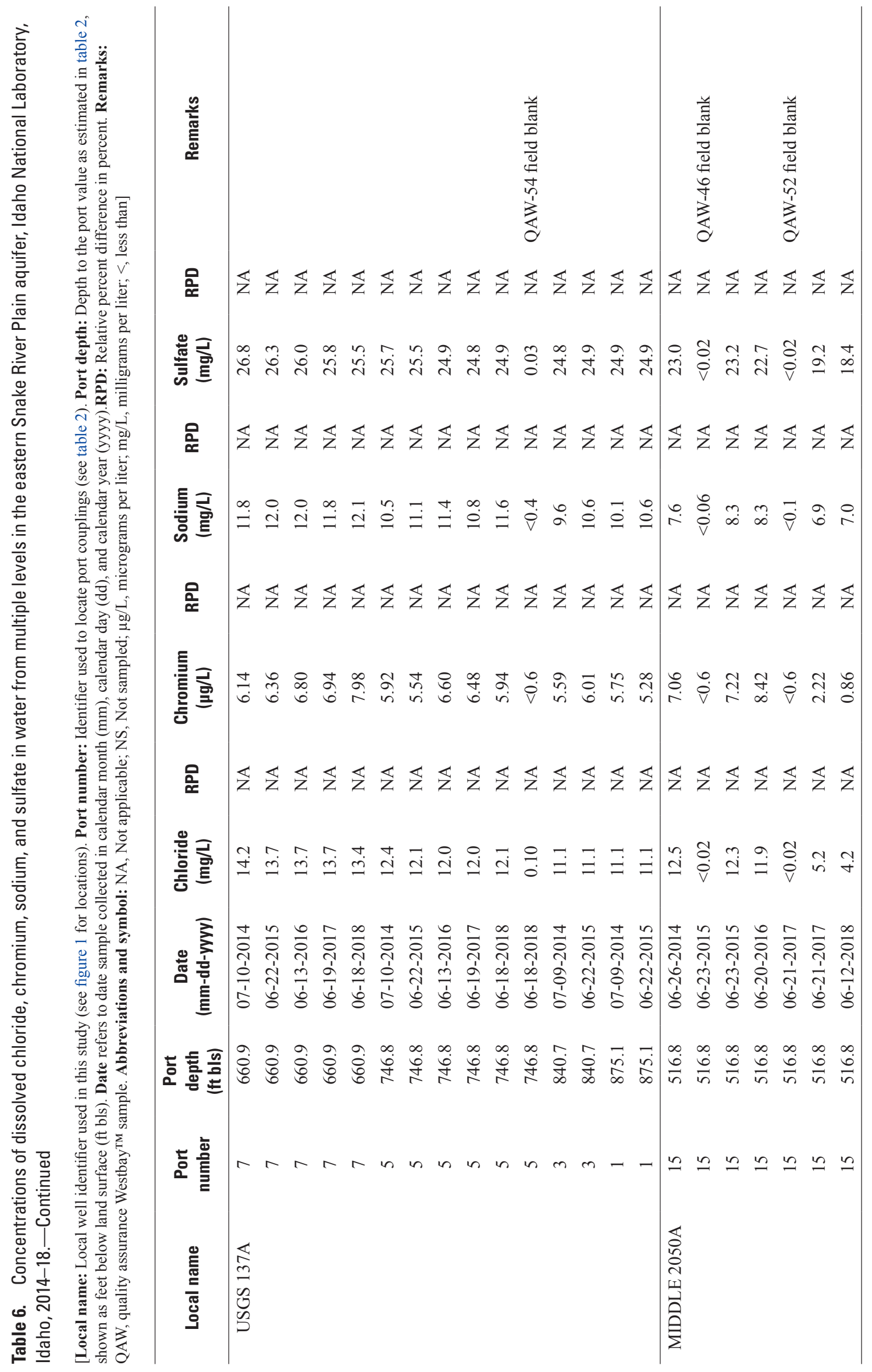




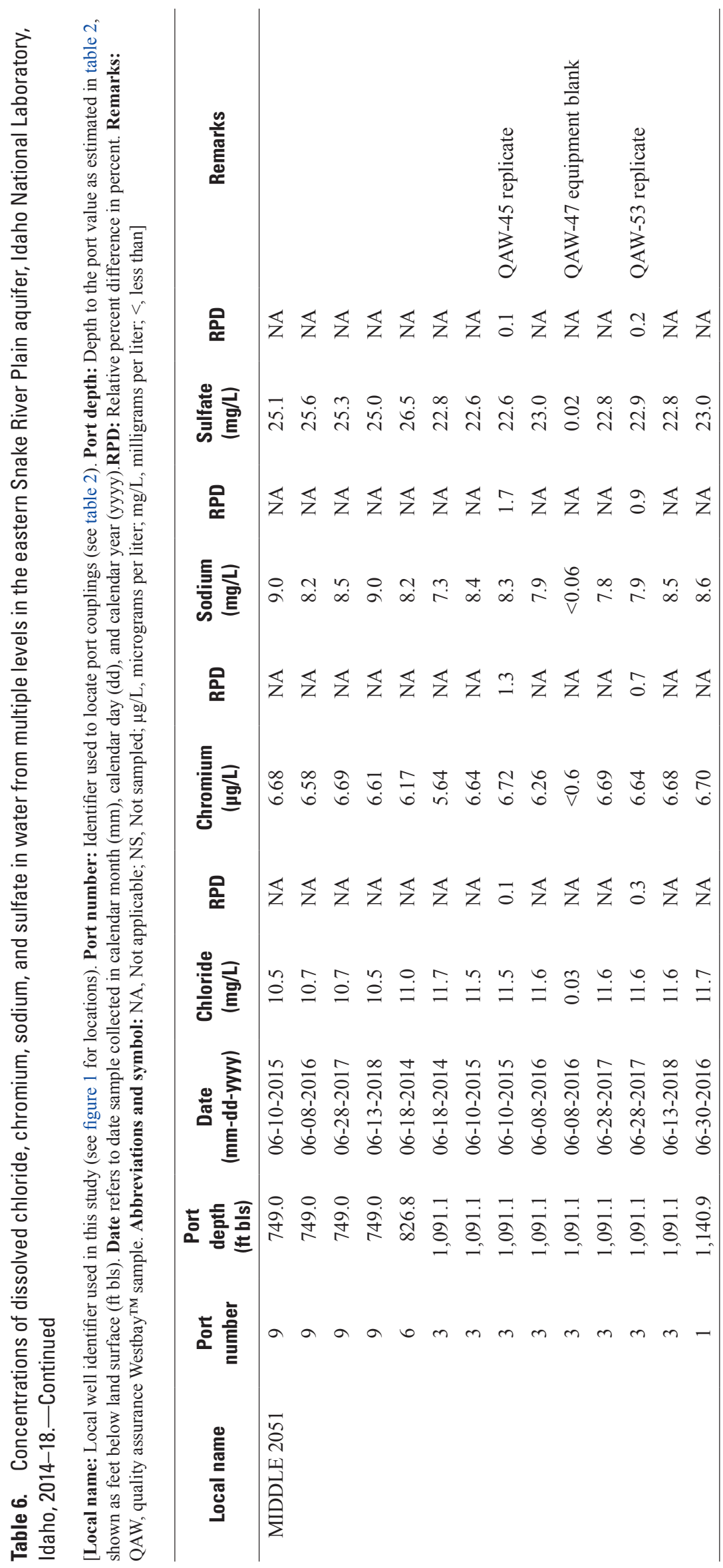




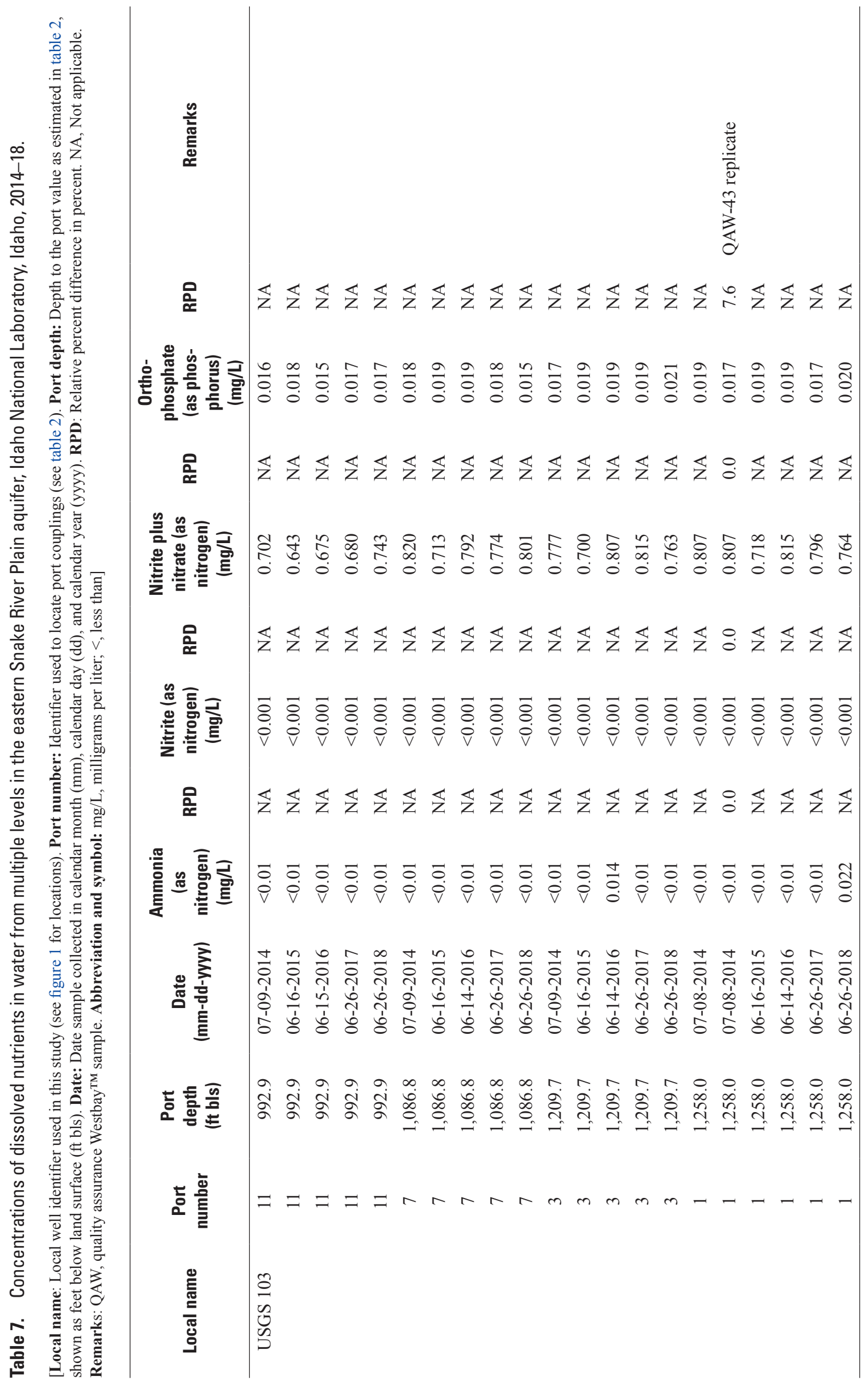




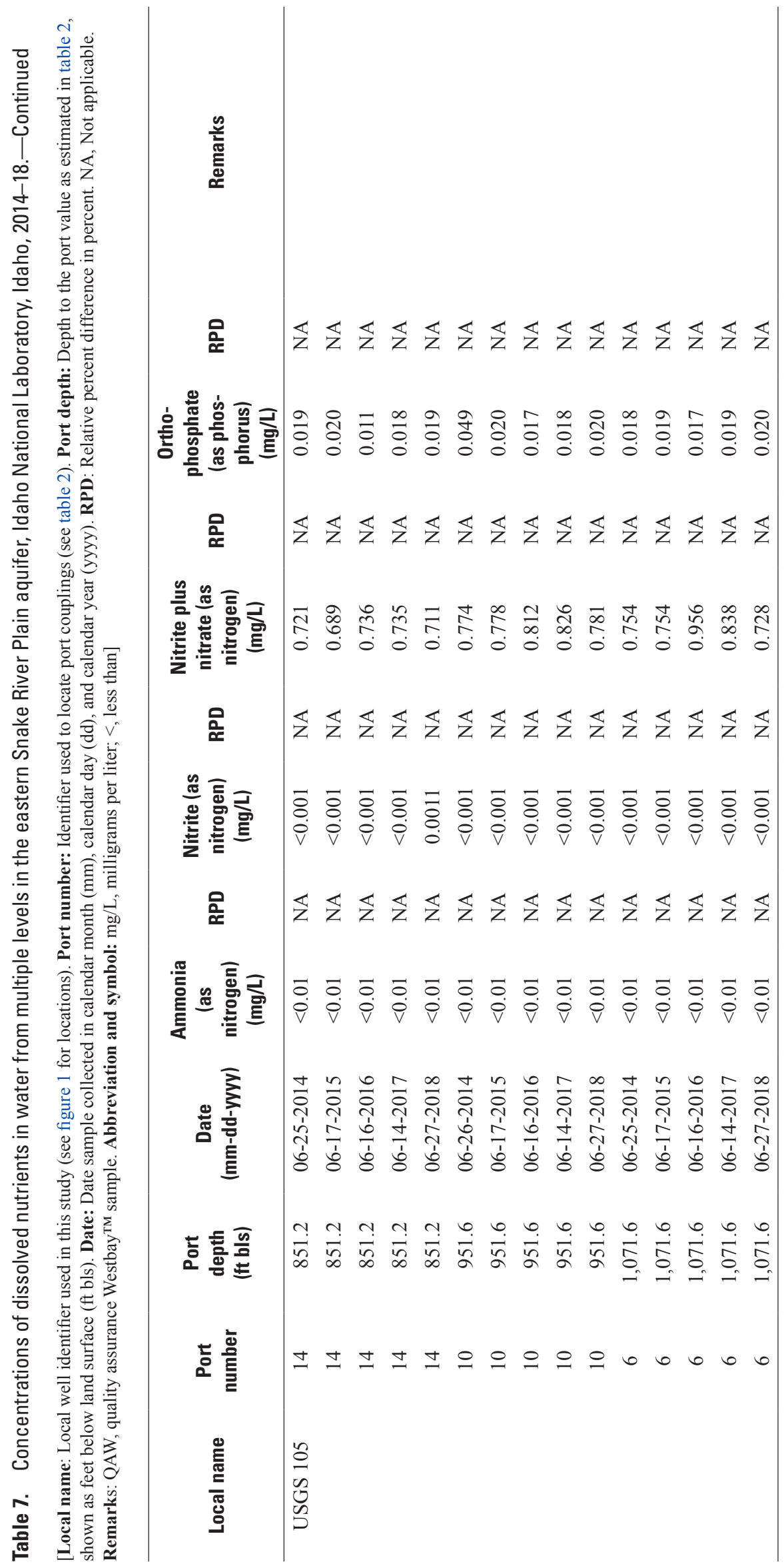


Table $7 \quad 67$

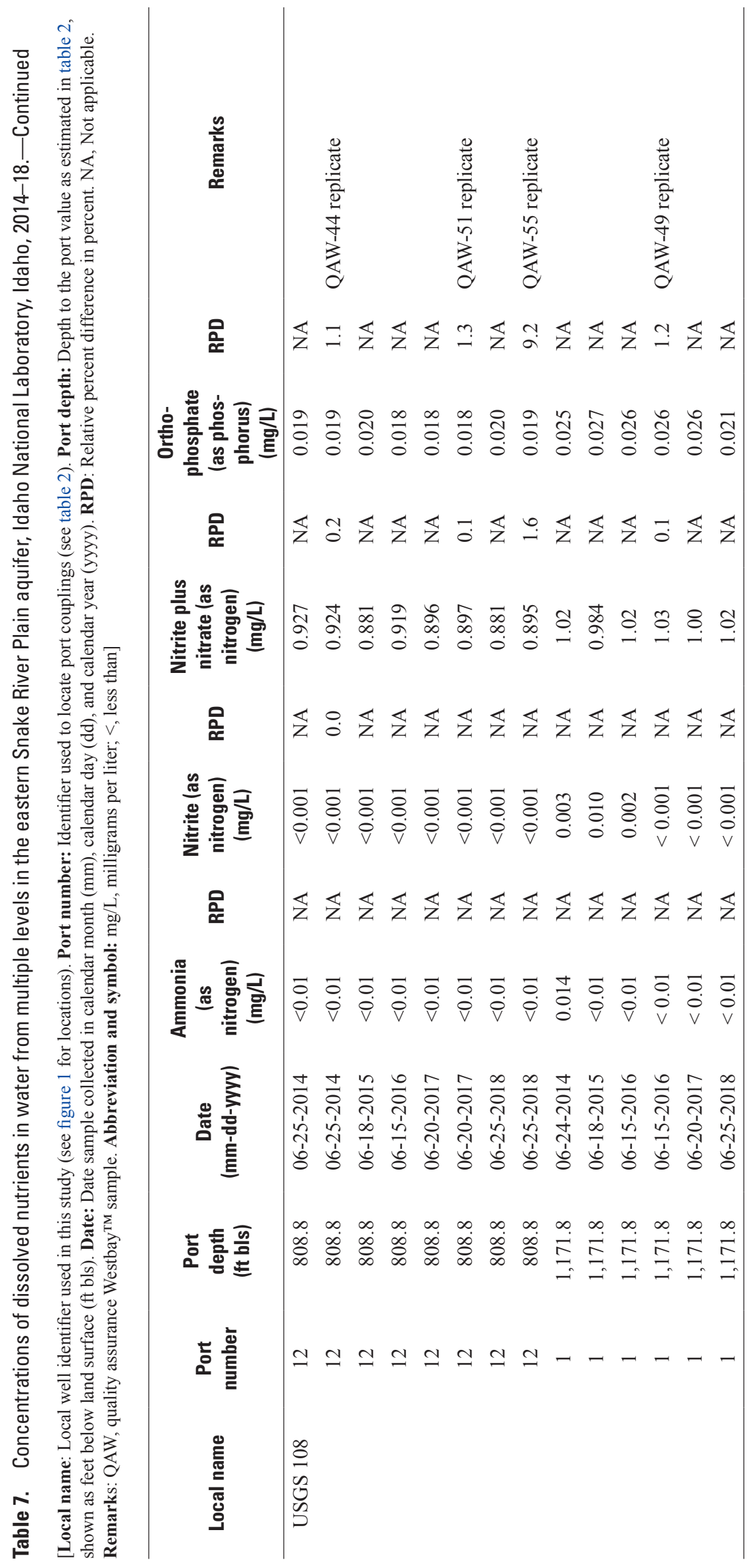




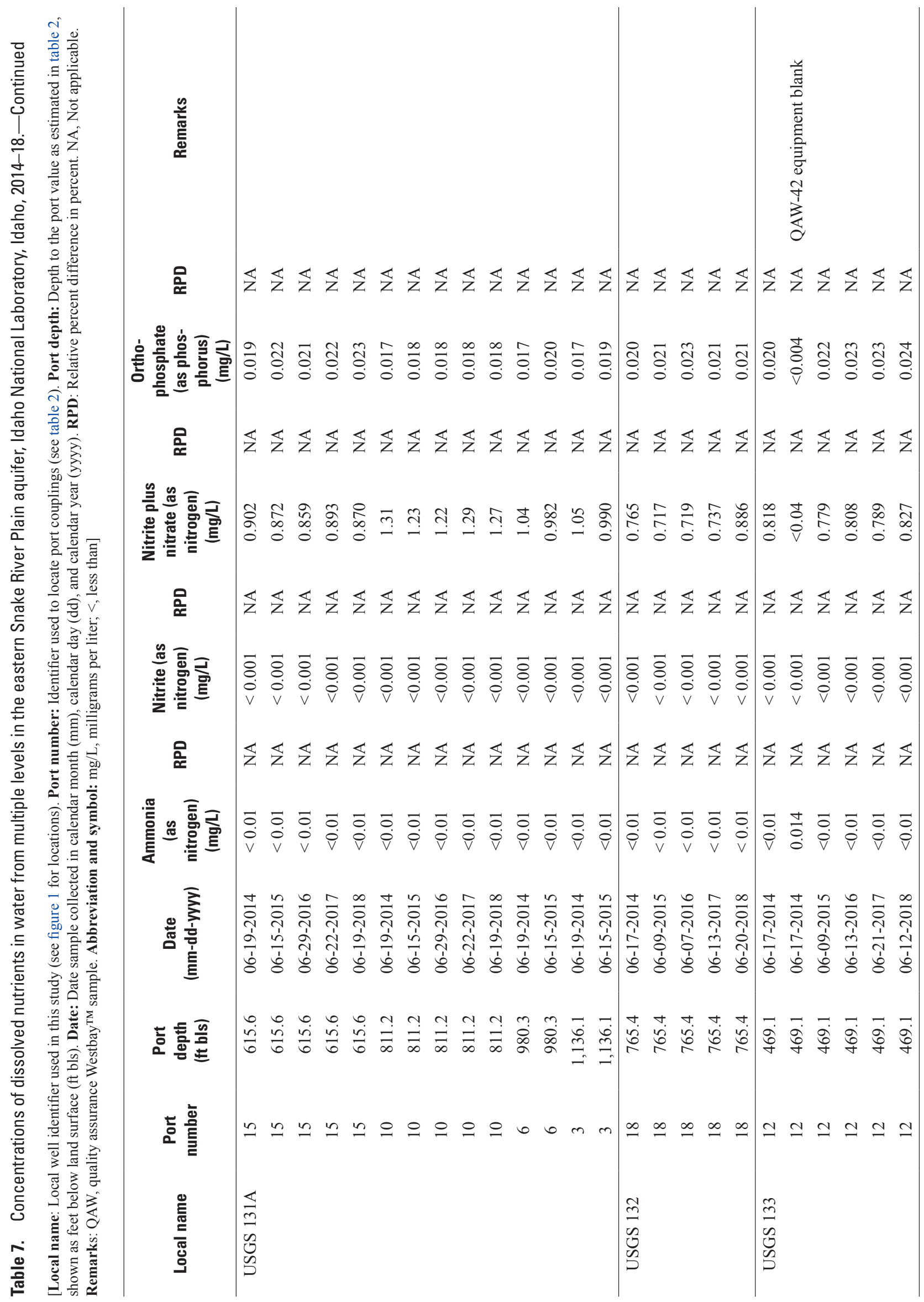




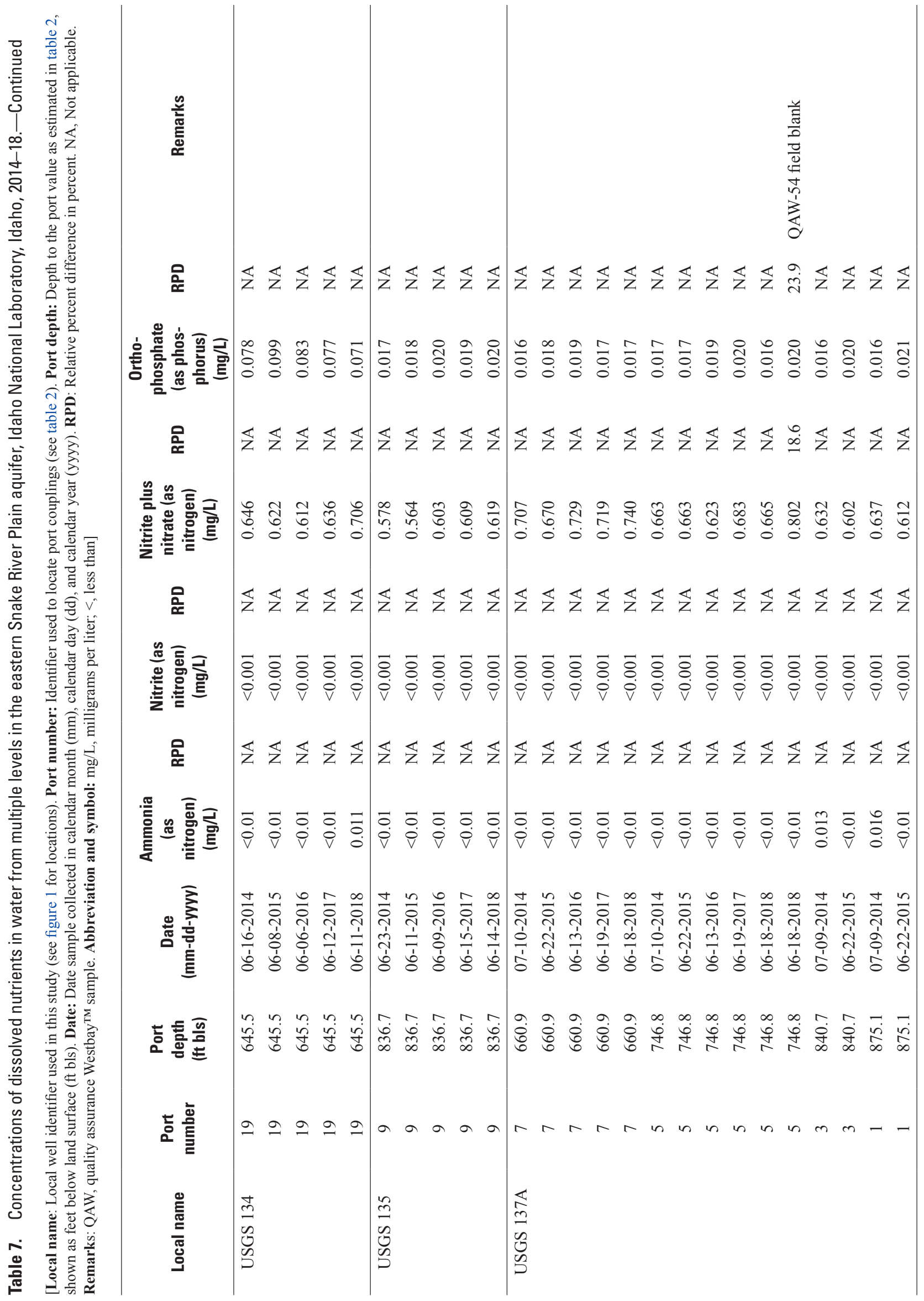




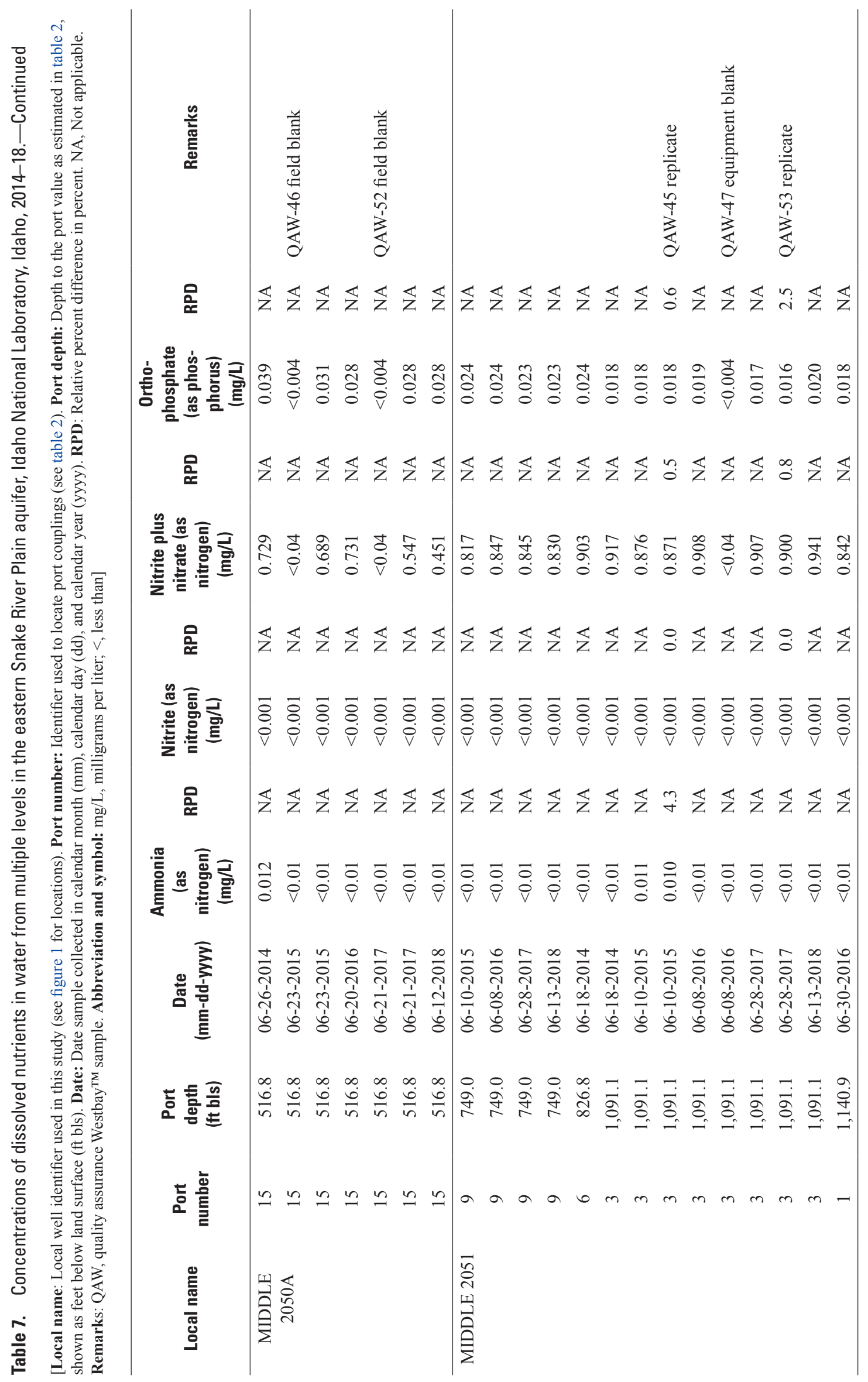




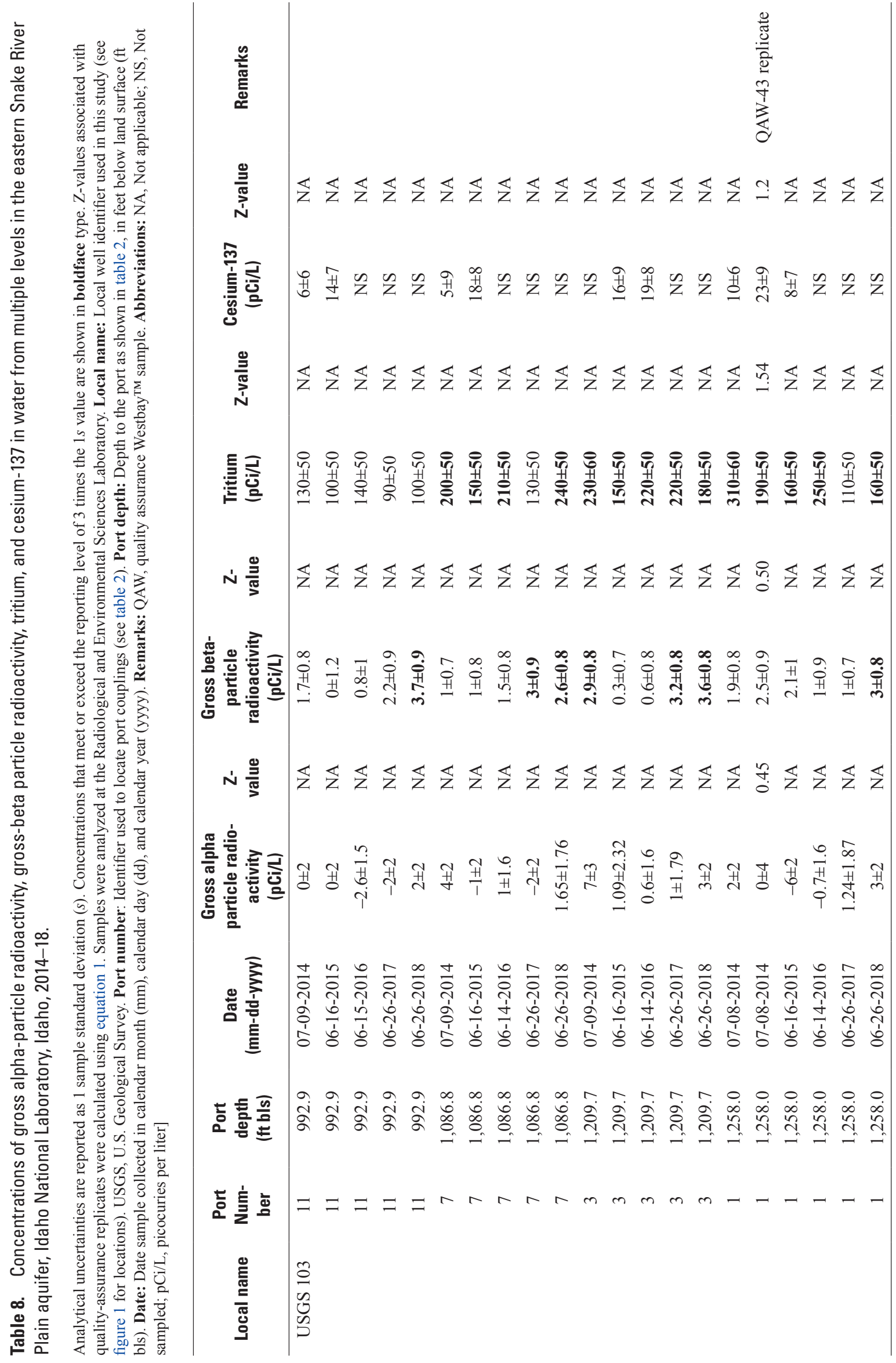




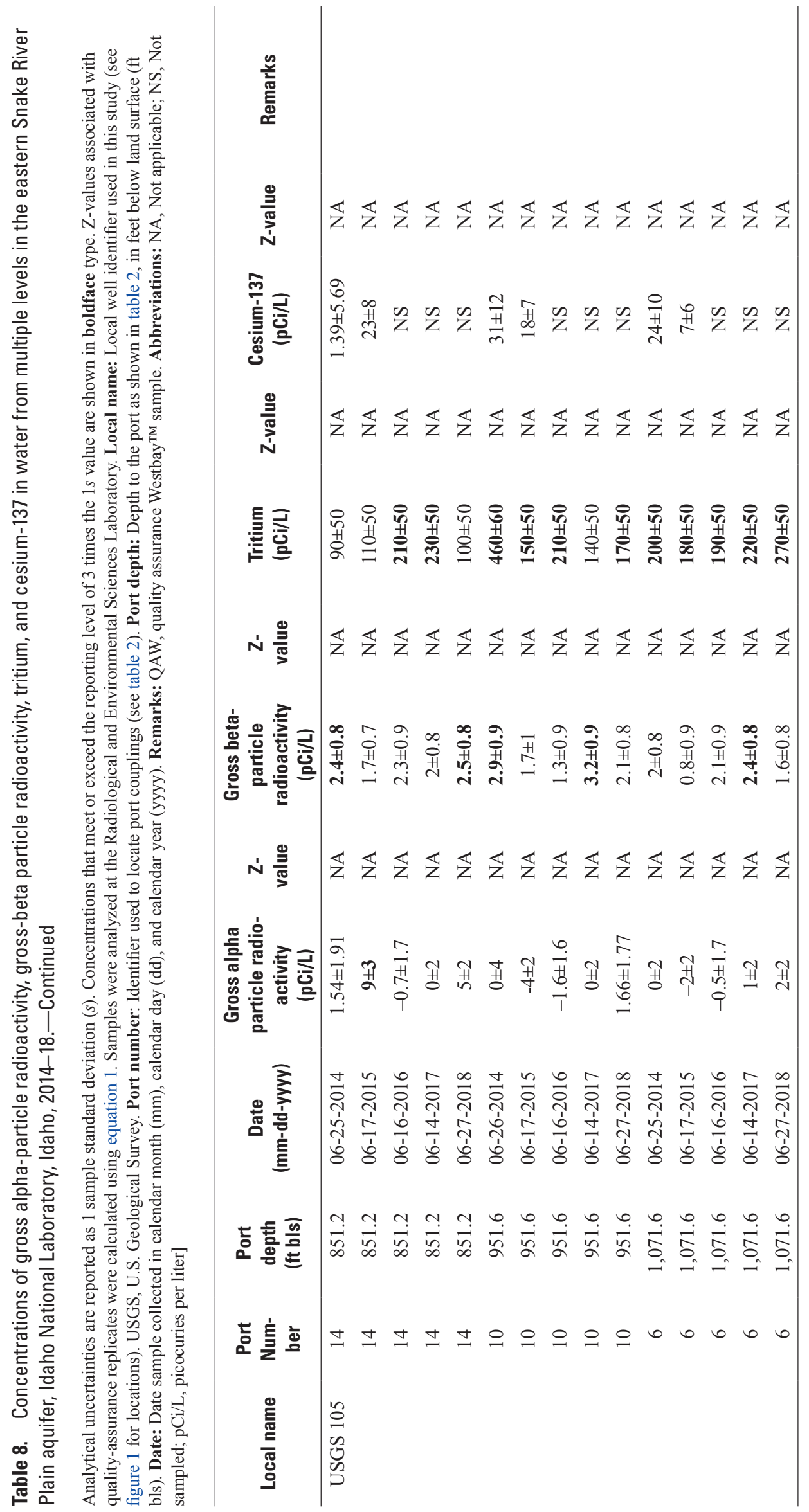




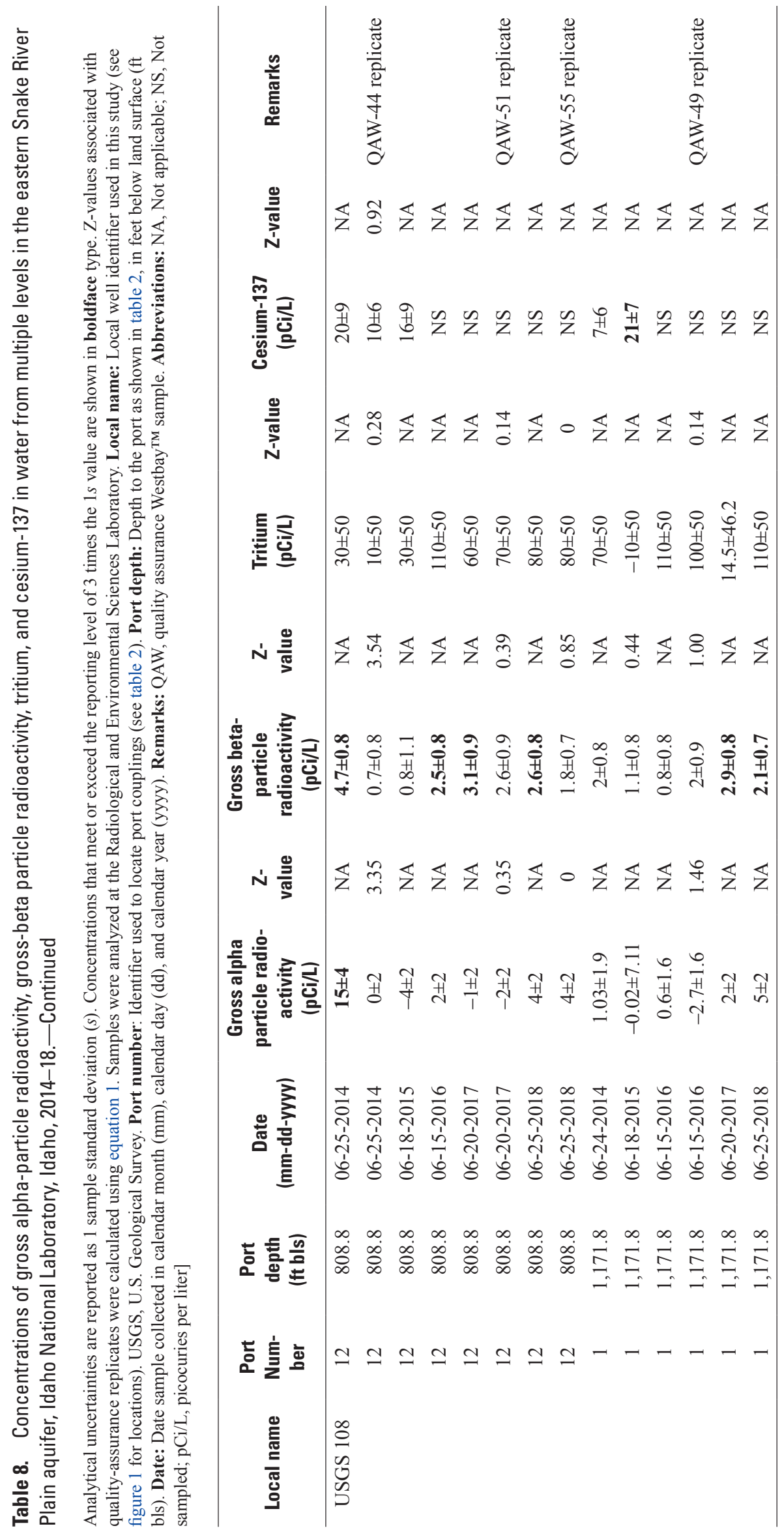




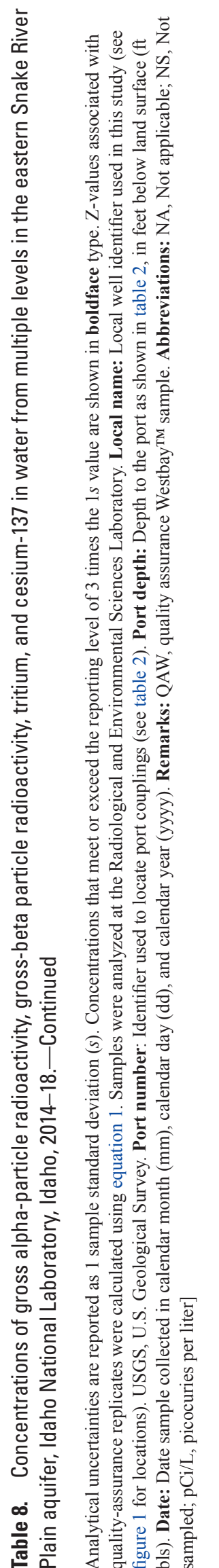

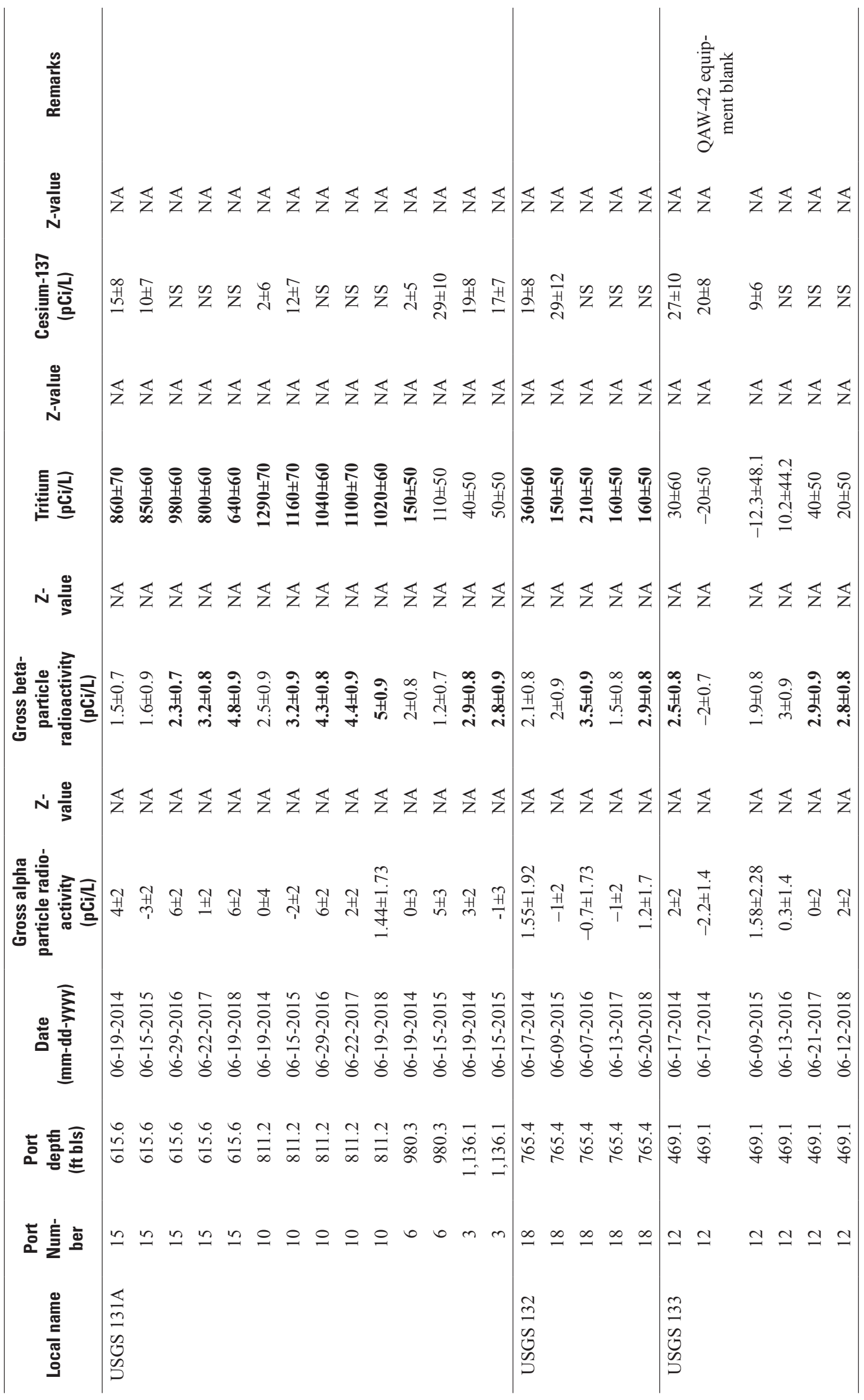




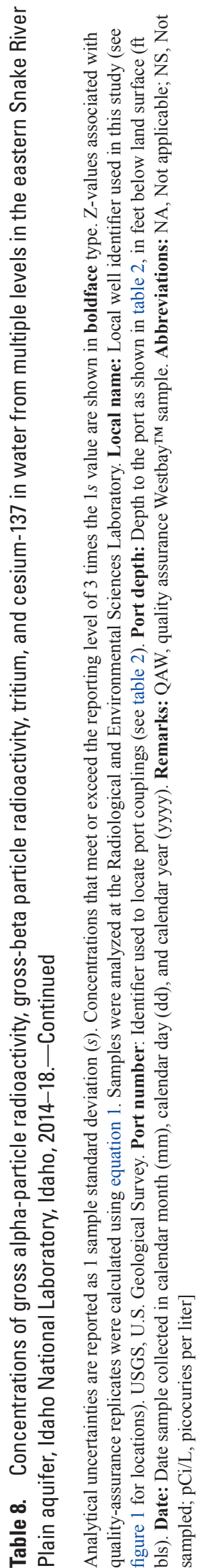

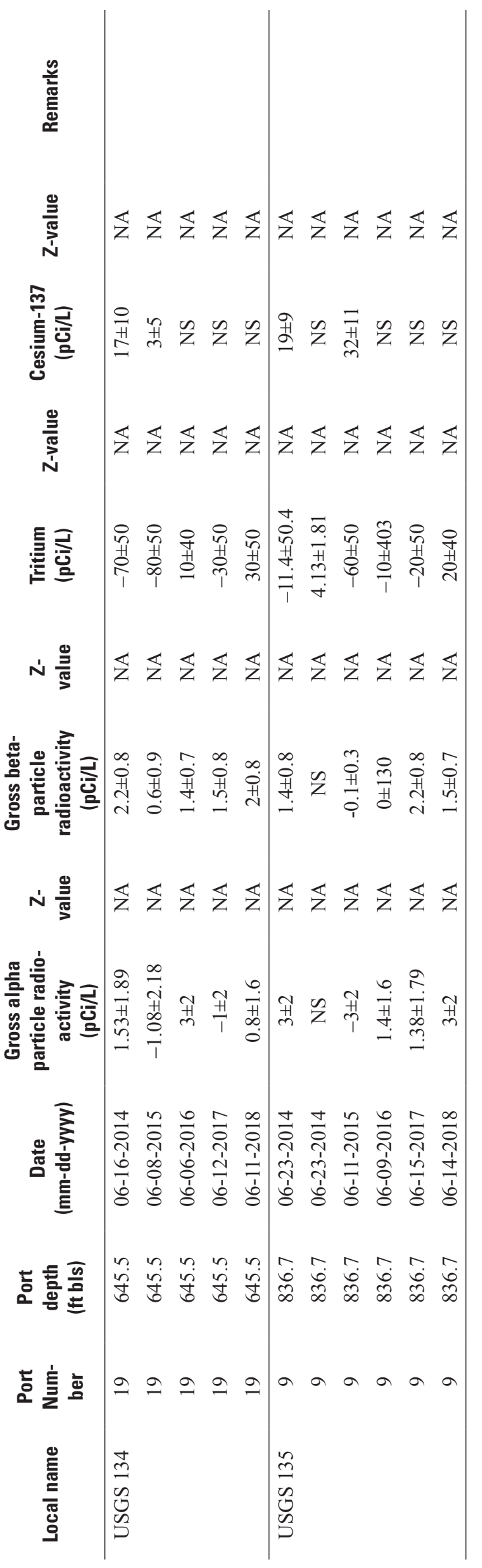




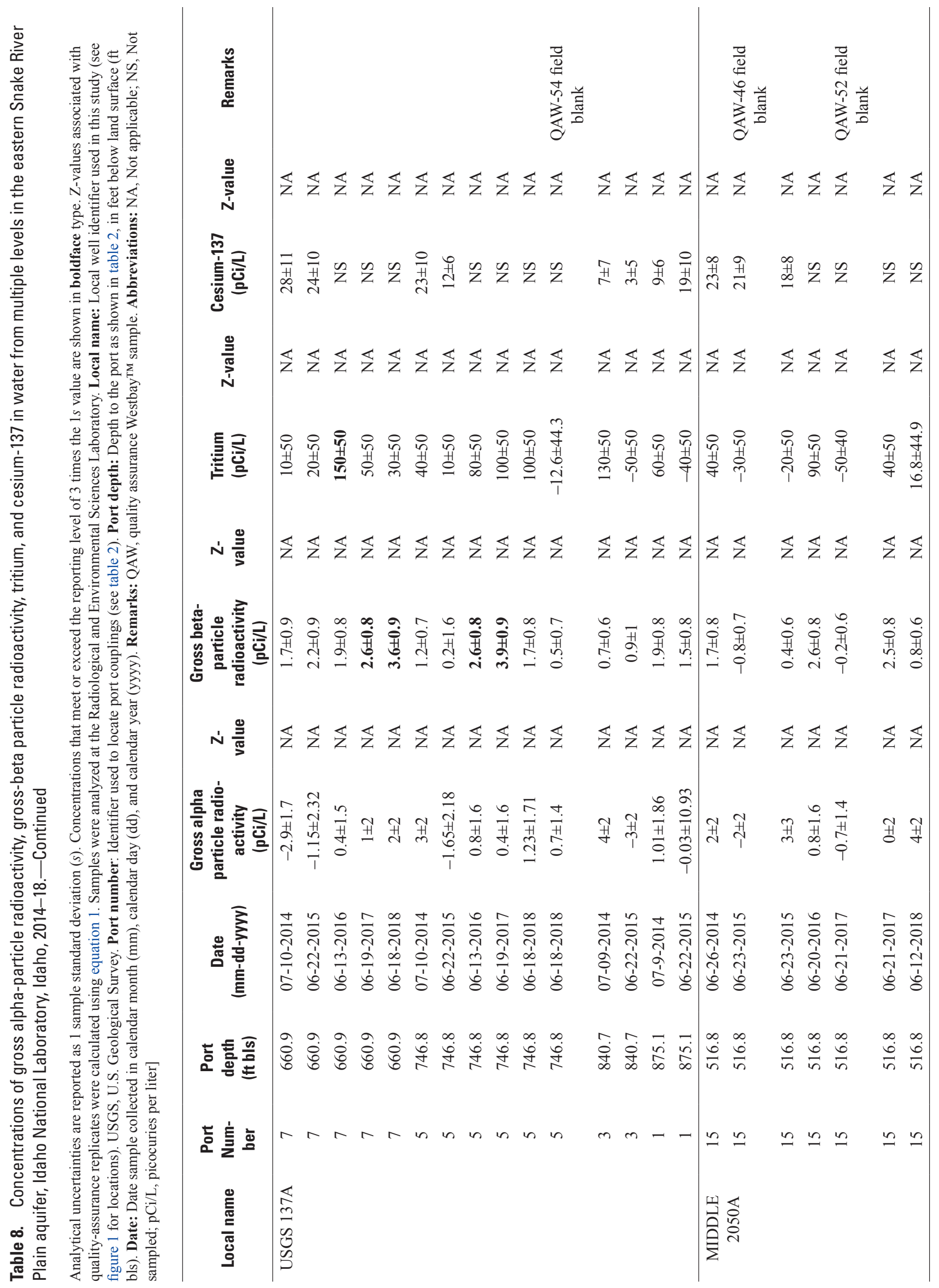




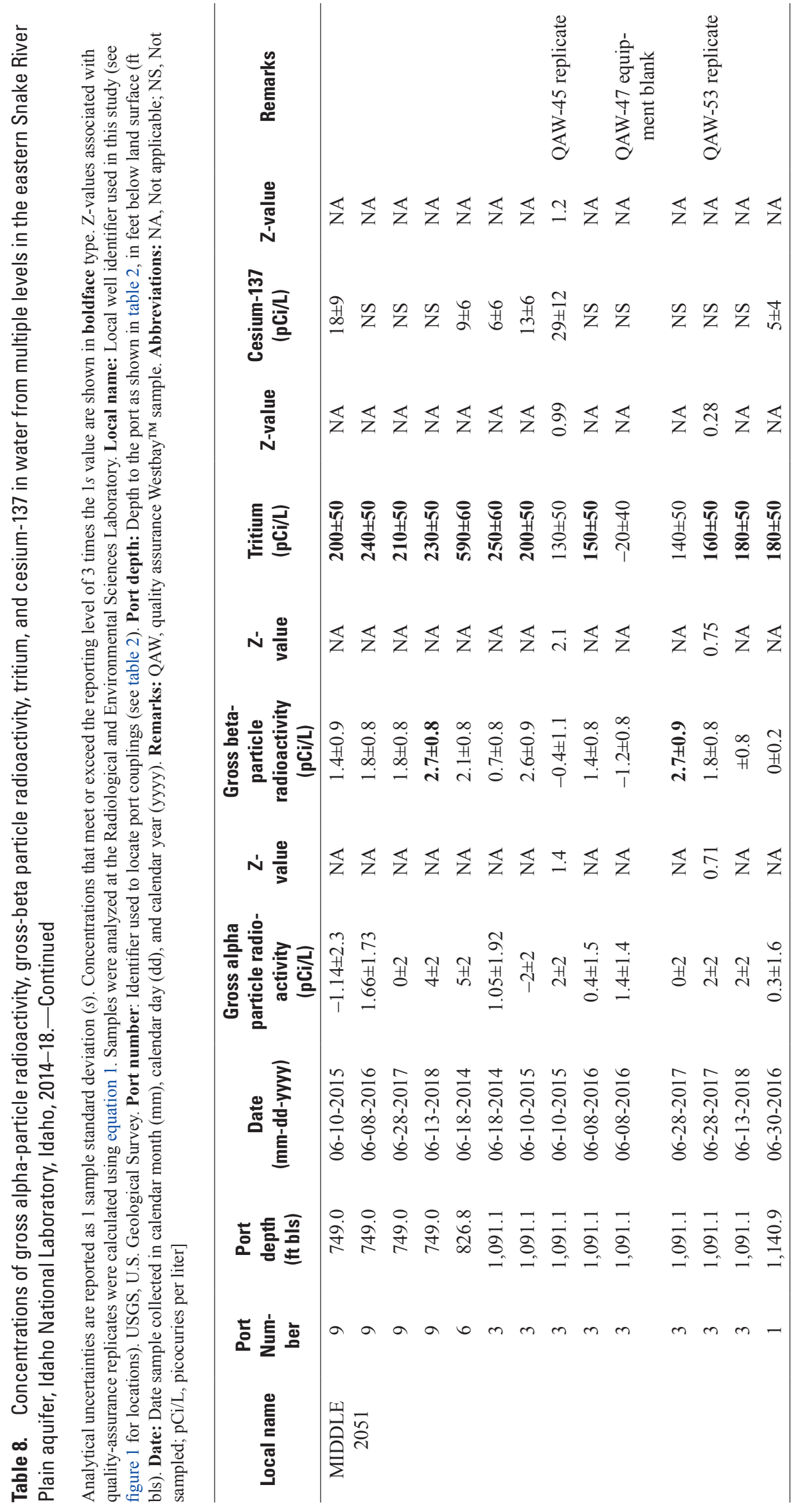


Table 9. Concentrations of selected chemical and radiochemical constituents in water from well MIDDLE 2051, Idaho National Laboratory, Idaho.

[See figure 1 for well location. Uncertainty of radiochemical constituents is 1 sample standard deviation $(s)$. Concentrations that meet or exceed the reporting level of 3 times the $1 s$ value are shown in boldface type. Analytical results are in micrograms per liter unless noted otherwise. Samples were analyzed at the U.S. Geological Survey (USGS) National Water Quality Laboratory in Lakewood, Colorado, unless otherwise indicated. Constituent or measurement: Sample date mm/dd/yy indicates month/day/year. Abbreviations and symbols: $\mathrm{CaCO}_{3}$, calcium carbonate; N, nitrogen; P, phosphorus; RESL, Radiological and Environmental Sciences Laboratory; RSIL, USGS Reston Stable Isotope Laboratory in Reston, Virginia; ${ }^{\circ} \mathrm{C}$, degrees Celsius; $\mu \mathrm{S} / \mathrm{cm}$, microsiemens per centimeter at 25 degrees Celsius; mg/L, milligrams per liter; pCi/L, picocuries per liter; <, less than; \pm , plus or minus ; NA, Not analyzed]

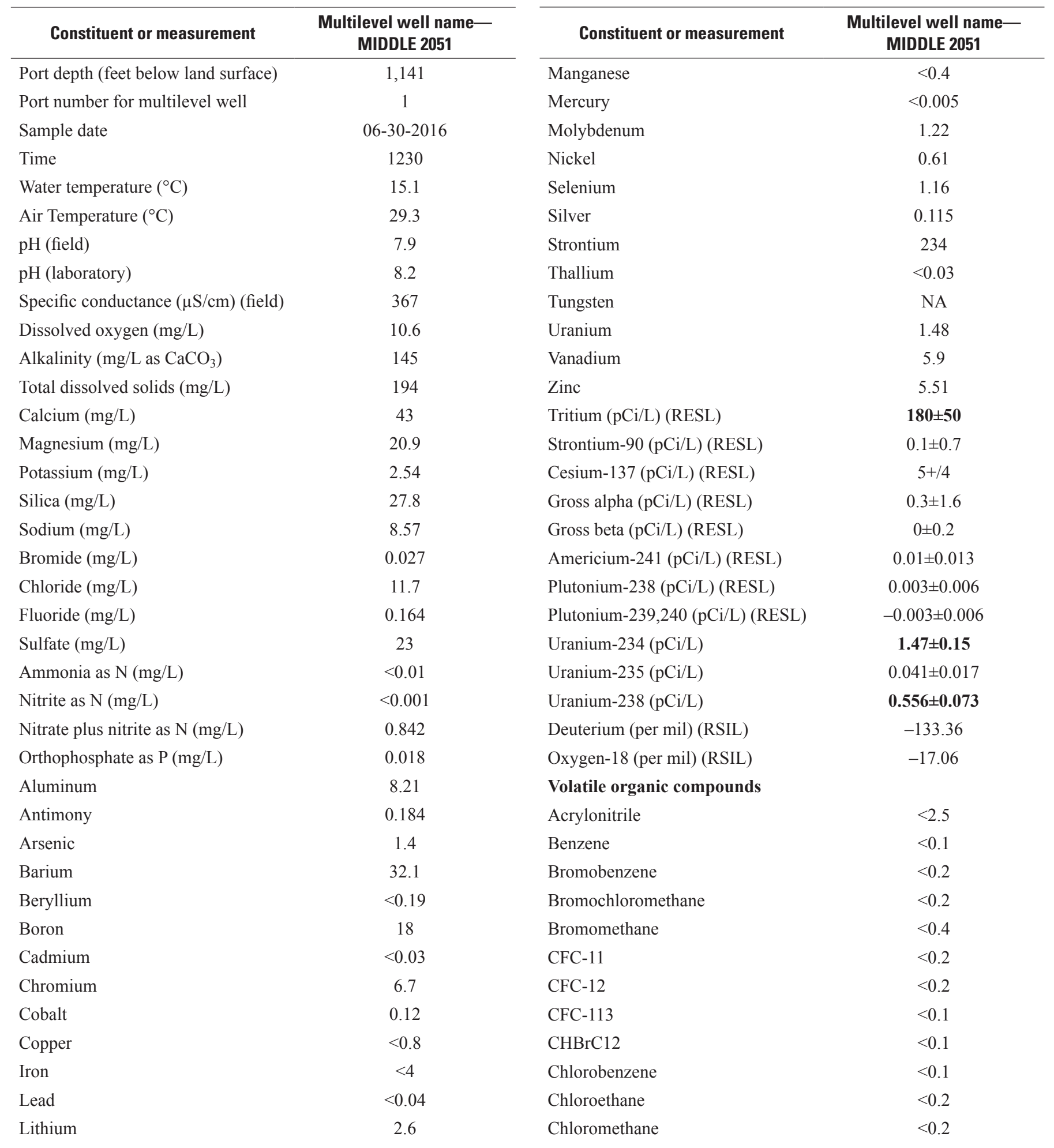


Table 9. Concentrations of selected chemical and radiochemical constituents in water from well MIDDLE 2051, Idaho National Laboratory, Idaho.-Continued

[See figure 1 for well location. Uncertainty of radiochemical constituents is 1 sample standard deviation $(s)$. Concentrations that meet or exceed the reporting level of 3 times the $1 s$ value are shown in boldface type. Analytical results are in micrograms per liter unless noted otherwise. Samples were analyzed at the U.S. Geological Survey (USGS) National Water Quality Laboratory in Lakewood, Colorado, unless otherwise indicated. Constituent or measurement: Sample date mm/dd/yy indicates month/day/year. Abbreviations and symbols: $\mathrm{CaCO}_{3}$, calcium carbonate; N, nitrogen; P, phosphorus; RESL, Radiological and Environmental Sciences Laboratory; RSIL, USGS Reston Stable Isotope Laboratory in Reston, Virginia; ${ }^{\circ} \mathrm{C}$, degrees Celsius; $\mu \mathrm{S} / \mathrm{cm}$, microsiemens per centimeter at 25 degrees Celsius; mg/L, milligrams per liter; $\mathrm{pCi} / \mathrm{L}$, picocuries per liter; $<$, less than; \pm , plus or minus; NA, Not analyzed]

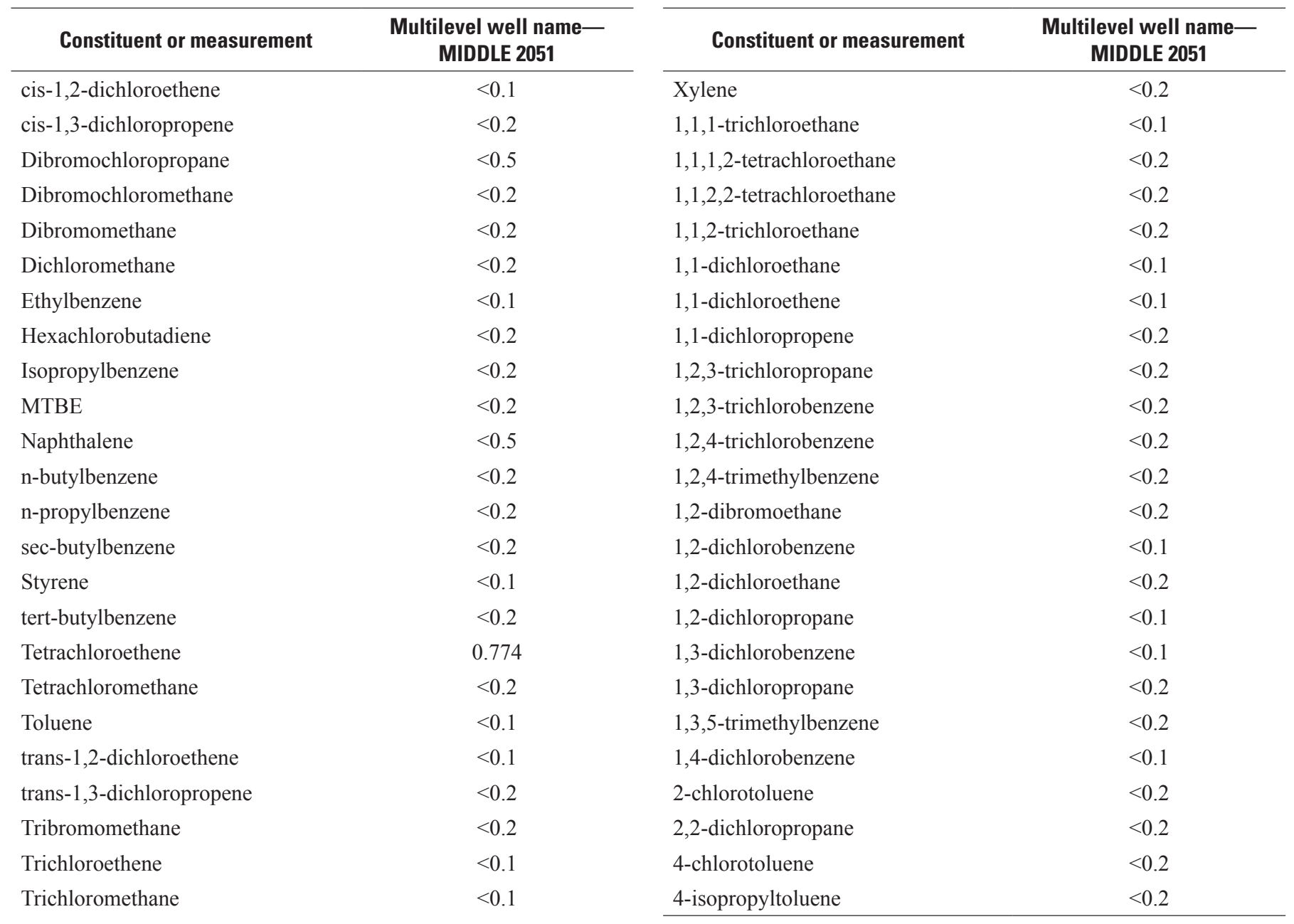

Vinyl chloride

$<0.2$ 


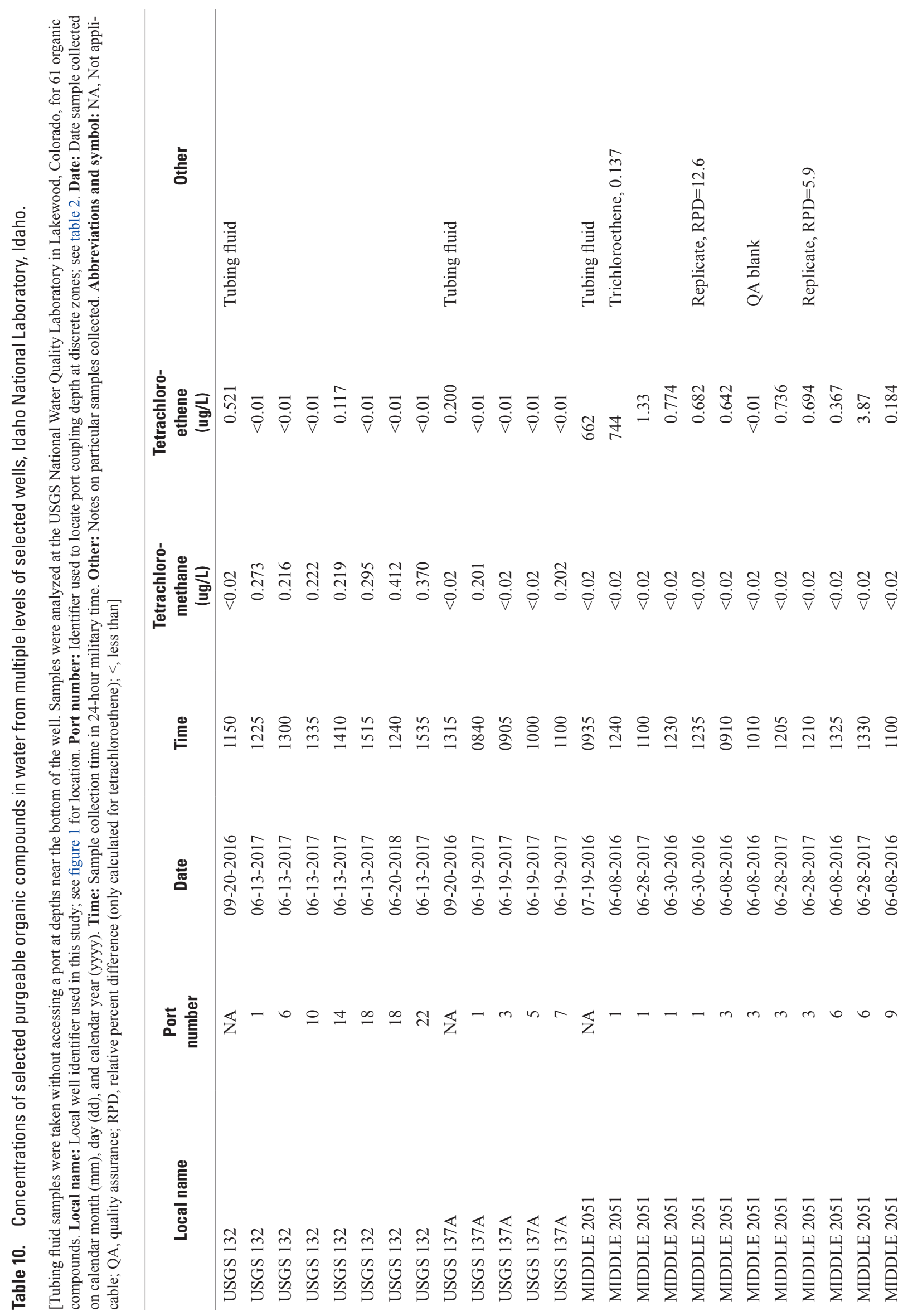


Table $10 \quad 81$

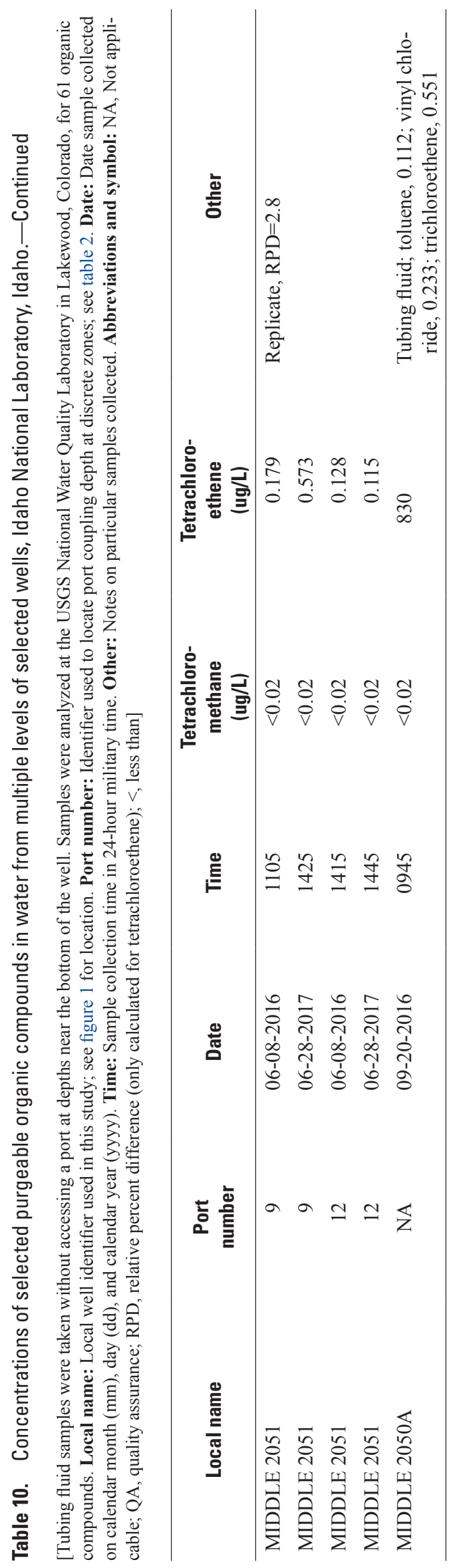


Appendix 1. Paired Port Statistics for Boreholes U.S. Geological Survey (USGS) 103, USGS 105, USGS 108, USGS 131A, USGS 132, USGS 133, USGS 134, USGS 135, and USGS 137A, Idaho National Laboratory, Idaho, 2014-18

Appendix 1 is a Microsoft Excel ${ }^{\circledR}$ table available for download at https://doi.org/10.3133/sir20215002.

Appendix 2. Atmospheric Pressure, Water Temperature, Fluid Pressure, and Hydraulic Head Data from Port Measurements for Boreholes U.S. Geological Survey (USGS) 103, USGS 105, USGS 108, USGS 131A, USGS 132, USGS 133, USGS 134, USGS 135, USGS 137A, MIDDLE 2050A, and MIDDLE 2051, Idaho National Laboratory, Idaho, 2014-18

Appendix 2 is a Microsoft Excel ${ }^{\circledR}$ table available for download at https://doi.org/10.3133/sir20215002.

Appendix 3. Mean and Normalized Mean Hydraulic Head Values for Boreholes U.S. Geological Survey (USGS) 103, USGS 105, USGS 108, USGS 131A, USGS 132, USGS 133, USGS 134, USGS 135, USGS 137A, MIDDLE 2050A, and MIDDLE 2051, Idaho National Laboratory, Idaho, 2007-18

Appendix 3 is a Microsoft Excel ${ }^{\circledR}$ table available for download at https://doi.org/10.3133/sir20215002. 
Publishing support provided by the U.S. Geological Survey Science Publishing Network, Tacoma Publishing Service Center

For more information concerning the research in this report, contact the Director, Idaho Water Science Center

U.S. Geological Survey

230 Collins Road

Boise, Idaho 83702-4520

https://www.usgs.gov/centers/id-water 
옹

灾 